Oceanography and Marine Biology: An Annual Review, 2006, 44, 123-195

(C) R. N. Gibson, R. J. A. Atkinson, and J. D. M. Gordon, Editors

Taylor \& Francis

\title{
MEDITERRANEAN CORALLIGENOUS ASSEMBLAGES: A SYNTHESIS OF PRESENT KNOWLEDGE
}

\author{
ENRIC BALLESTEROS \\ Centre d'Estudis Avançats de Blanes - CSIC, \\ Accés Cala Sant Francesc, 14, E-17300 Blanes, Girona, Spain \\ E-mail: kike@ceab.csic.es
}

\begin{abstract}
Coralligenous concretions, the unique calcareous formations of biogenic origin in Mediterranean benthic environments, are produced by the accumulation of encrusting algae growing in dim light conditions. This review provides an overview of the results obtained by the main studies dealing with these formations, including the environmental factors which influence the development of coralligenous communities, their distribution, types, assemblages, builders and eroders, the biotic relationships and processes that create and destroy coralligenous assemblages, their dynamics and seasonality, and the functioning of several outstanding and key species. Special attention is devoted to the biodiversity of coralligenous communities and a first estimation of the number of species reported for this habitat is provided. Major disturbances affecting coralligenous communities are discussed, ranging from large-scale events that are probably related to global environmental changes to degradation by waste water or invasive species. Degradation by fishing activities and by divers is also considered. Finally, the main gaps in current scientific knowledge of coralligenous communities are listed and some recommendations are made regarding their protection.
\end{abstract}

\section{Introduction and description}

Encrusting calcareous algae are important components of benthic marine communities within the euphotic zone (Blanc \& Molinier 1955, Adey \& McIntyre 1973, Littler 1973a, Lebednik 1977, James et al. 1988, Dethier et al. 1991, Adey 1998) and their historical roles as reef builders have been chronicled thoroughly by Wray (1977). Coralline algae are major contributors to coral reef frameworks (Finckh 1904, Hillis-Colinvaux 1986, Littler 1972) where they usually are the dominant reef-forming organisms (Foslie 1907, Odum \& Odum 1955, Lee 1967, Littler 1973b). Although encrusting corallines are adapted to grow at low light conditions (Littler et al. 1986, Vadas \& Steneck 1988), coralline algal reef frameworks are usually restricted to littoral or shallow sublittoral environments throughout the marine realm (e.g., Littler 1973b, Adey \& Vassar 1975, Laborel et al. 1994) because they easily withstand turbulent water motion and abrasion (Littler \& Doty 1975, Adey 1978). The only known exception to this restriction is the coralligenous framework, a coralline algal concretion that thrives exclusively in Mediterranean deep waters (20-120 m depth).

There is no real consensus among scientists studying benthic communities in the Mediterranean Sea about what a coralligenous habitat is. In this review a coralligenous habitat is considered to be a hard substratum of biogenic origin that is mainly produced by the accumulation of calcareous encrusting algae growing in dim light conditions. Algae and invertebrates growing in environments with low light levels are called sciaphilic in opposition to photophilic, that is, growing at high light levels. All plants and animals thriving in coralligenous habitats are, thus, sciaphilic. Although more 


\section{ENRIC BALLESTEROS}

extensive in the circalittoral zone, coralligenous habitats can also develop in the infralittoral zone, provided that light is dim enough to allow growth of the calcareous algae that produce the calcareous framework. Infralittoral coralligenous concretions always develop on almost vertical walls, in deep channels, or on overhangs, and occupy small surface areas. Communities developing in low light conditions near sea level, in sites of strong water movement and usually below the mediolittoral biogenic rim of the coralline alga Lithophyllum byssoides (Boudouresque \& Cinelli 1976), are not considered in this review, even though they may exhibit small concretions of coralline algae. Other algal dominated communities thriving in the circalittoral zone, such as rhodolith beds (Basso \& Tomaselli 1994) or Cystoseira zosteroides assemblages (Ballesteros 1990), are also excluded, as the coralline algal framework in these cases is reduced or almost nil. Some facies of coralligenous communities (and which are categorized as "pre-coralligenous" by several authors, e.g., Pérès \& Picard 1964, Gili \& Ros 1985, Ros et al. 1985) are also excluded from this review, but only if they refer to sciaphilic communities without a basal framework of coralline algae. Therefore, the main criterion used to define the coralligenous habitat is the presence of a bioherm of coralline algae grown at low irradiance levels and in relatively calm waters. This bioherm is always very complex in structure and, in fact, allows the development of several kinds of communities (Laborel 1961, Laubier 1966), including those dominated by living algae (upper part of the concretions), suspension feeders (lower part of the concretions, wall cavities and overhangs), borers (inside the concretions) and even soft-bottom fauna (in the sediment deposited in cavities and holes). Therefore, the coralligenous habitat should be considered more as a submarine landscape or community puzzle rather than a single community.

\section{History and main studies}

\section{Historical account of general and faunal studies}

The word 'coralligenous' (coralligène in French) was first used by Marion (1883) to describe the hard bottoms that fishermen from Marseilles called broundo and which are found at a depth of between 30 and $70 \mathrm{~m}$, below seagrass meadows of Posidonia oceanica and above coastal muddy bottoms. Coralligène means 'producer of coral' and is related to the abundance of red coral (Corallium rubrum) found on this type of bottom. Marion (1883) includes long lists of fauna collected in these coralligène bottoms. Pruvot $(1894,1895)$ also used the word coralligène to describe similar bottoms in the Pyrenees region of the Mediterranean (Banyuls), and this terminology was included in bionomical descriptions of Mediterranean sea bottoms from the end of the nineteenth century. Feldmann (1937) subsequently described in detail the algal composition of the coralligenous assemblages from Banyuls and identified the main calcareous algae responsible for coralligenous bioherms. He also made observations of the animals contributing to the framework and of bioeroders. Pérès \& Picard (1951) continued the work of Marion (1883) on coralligenous bottoms from the Marseilles region, defining the components of the coralligenous assemblages; they demonstrated their high microspatial variability and described the environmental factors which allow them to develop.

Elsewhere in the Mediterranean, Bacci (1947), Tortonese (1958), Rossi (1958, 1961), Parenzan (1960) and Molinier (1960) characterized the pre-coralligenous and coralligenous bioherms in some areas of the Italian coast and Corsica and Pérès \& Picard (1958) described the coralligenous communities from the northeastern Mediterranean. The last authors reported several warm-water species, as well as the absence of various species that dominate coralligenous concretions in the western Mediterranean. Laborel $(1960,1961)$ also expanded the study of coralligenous communities to other Mediterranean areas, including the eastern Mediterranean. He described five main coralligenous types (cave and overhang concretions, wall concretions, concretions at the base of submarine 


\section{MEDITERRANEAN CORALLIGENOUS ASSEMBLAGES}

walls, concretions over flat rocky surfaces and platform coralligenous assemblages) and, in his 1960 paper, also provided the first quantified lists of algal and animal species obtained by scuba diving.

In 1964 Pérès \& Picard (1964) summarised existing knowledge of coralligenous communities, defining the notion of pre-coralligenous and simplifying the categories of Laborel (1961) into two coralligenous types: coralligenous assemblages over littoral rock and bank or platform coralligenous assemblages, according to the original substratum (rock or sediment) where concretion began. They proposed an evolutionary series relating the different biocenoses of the circalittoral zone in the Mediterranean and suggested that the coralligenous community was the climax biocenosis of this zone. They also used the word 'precoralligenous' to refer to a facies with a great development of erect, noncalcareous, sciaphilic algae and a low cover of invertebrates. An English summary of Pérès \& Picard's (1964) work can be found in Pérès (1967). At about the same time, Vaissière (1964), Fredj (1964) and Carpine (1964) made interesting contributions to the distribution and bionomic description of coralligenous concretions in the region of Nice and Monaco, east of Marseilles.

Gamulin-Brida (1965) conducted the first bionomical studies of coralligenous communities in the Adriatic Sea and concluded that they are biogeographically very similar to those found in the northwestern Mediterranean, with a great abundance of large bryozoans, gorgonians and alcyonarians.

Laubier (1966) made a major contribution to knowledge of invertebrates living in coralligenous assemblages, with his study based on data from the Pyrenean region of the Mediterranean. He was the first to report the high biodiversity of these substrata, he carefully studied the fauna of the concretions (particularly accurate are the studies on polychaetes, copepods and echinoderms) and defined the physico-chemical conditions allowing the coralligenous communities to develop. He was also the first to make a large number of observations related to the natural history of the species inhabiting coralligenous assemblages and, in particular, referred to the relationships of epibiosis, endobiosis, commensalism and parasitism. Subsequent to Laubier's studies, Sarà (1968, 1969) described the coralligenous communities in the Pouilles region (Italy) and True (1970) collected quantitative samples from the coralligenous assemblages of Marseilles, providing data on the biomass of the main species of suspension feeders.

Hong $(1980,1982)$ exhaustively described the coralligenous communities from Marseilles and the effects of sewage on their fauna. He also described the animals that contribute to these coralligenous frameworks and defined four different categories of invertebrates which can be distinguished by considering their ecological significance in the assemblages. Extensive lists of several taxonomic groups (mainly foraminiferans, sponges, molluscs, pycnogonids, amphipods and bryozoans) greatly increased the knowledge of the biodiversity of coralligenous communities.

Gili \& Ros (1984) reviewed the coralligenous communities of the Medes Islands, off the northeast coast of Spain, and accurately evaluated the total surface area occupied by coralligenous assemblages in this marine reserve (Gili \& Ros 1985). Detailed species lists of most algal and animal groups for coralligenous communities from specific areas of the Spanish Mediterranean can also be found in Ballesteros et al. (1993) and Ballesteros \& Tomas (1999). Sartoretto (1996) studied the growth rate of coralligenous buildups by radiocarbon dating and related the growth periods to different environmental conditions, mainly the eustatic water level and the transparency of the water column. He also identified the main calcareous algae that finally produce the framework and emphasised the importance of Mesophyllum alternans. The effect of sedimentation and erosion by browsers and borers was also quantified.

\section{Algal studies}

Feldmann (1937) was the first to describe unequivocally the algal composition of coralligenous assemblages; he differentiated these substrata from the deep-water algal beds of Cystoseira spinosa 


\section{ENRIC BALLESTEROS}

and $C$. zosteroides, and identified the main calcareous algae responsible for coralligenous deposition. The algal community growing on coralligenous assemblages was named the Pseudolithophyllum expansum-Lithophyllum hauckii association.

Scuba diving was first used in the study of algal flora of coralligenous assemblages by Giaccone (1965), who made some species lists of coralligenous communities and described a particular plant association, the Pseudolithophyllo-Halimedetum platydiscae in the area of Palermo (Sicily). Giaccone \& De Leo (1966) also used scuba diving to study the coralligenous and precoralligenous communities of the Gulf of Palermo by using the phytosociological method of Braun Blanquet. They distinguished both types of communities and referred to them as an association of Lithophyllum expansum and Lithothamnion philippi (coralligenous) and an association of Halimeda platydisca and Udotea desfontainii (precoralligenous). The population of Laminaria rodriguezii growing over a coralligenous community at the island of Ustica was also studied by Giaccone (1967), although this endemic Mediterranean kelp is usually more abundant in deep-water rhodolith beds (fonds à pralinés) (Molinier, 1956).

Boudouresque (1970) studied the macroalgal communities of coralligenous concretions as part of a detailed and exhaustive study of the sciaphilic benthic communities in the western Mediterranean. The accurate methodology (Boudouresque, 1971) included scuba sampling and further sorting and identification in the laboratory. Augier et al. (1971) used the same methods to study the algal sciaphilic communities around the island of Port-Cros (France).

Boudouresque (1973) proposed that the terms coralligenous and precoralligenous be avoided, as they have a physiognomical value but do not refer to any bionomical or phytosociological entity; instead, he joined all the sciaphilic algal settlements under relatively sheltered conditions into one association (Peyssonnelietum rubrae), and created two subassociations, corresponding to the assemblages developing in the infralittoral zone (Peyssonnelietum aglaothamnietosum) and the circalittoral zone (Peyssonnelietum rodriguezelletosum). He reported the high biodiversity of these assemblages and defined the ecological group of algae characteristic of coralligenous concretions (CC or Rodriguezellikon).

Augier \& Boudouresque (1975) argued that the algal composition of coralligenous communities thriving in deep water differs from that of sciaphilic assemblages from the infralittoral zone, and named it Rodriguezelletum strafforellii according to phytosociological nomenclature.

Boudouresque (1980) and Coppejans \& Hermy (1985) made significant contributions to the study of algal assemblages of coralligenous communities in Corsica, but Ballesteros (1991a,b,c, 1992) was the first to provide data on the dynamics and small-scale structure of algal assemblages from coralligenous communities.

Giaccone et al. (1994) conducted a phytosociological review of sciaphilic assemblages described for the Mediterranean. According to this review, most phytobenthic coralligenous assemblages should be included in the order Lithophylletalia, where two associations are distinguished: the Lithophyllo-Halimedetum tunae described by Giaccone (1965) and the Rodriguezelletum strafforellii described by Augier \& Boudouresque (1975). Phytobenthic assemblages growing in coralligenous concretions on vertical walls and overhangs in the infralittoral zone should be included in the order Rhodymenietalia, and mainly belong to the association Udoteo-Peyssonnelietum squamariae described by Molinier (1960) in Corsica, and which seems to be identical to the association of Peyssonnelia squamaria described by Feldmann (1937) for the Pyrenees region of the Mediterranean.

Contributions by Ferdeghini et al. (2000) and Acunto et al. (2001), using photographic sampling, demonstrated the small-scale variability in algal assemblages from coralligenous communities, mainly due to the patchy distribution of calcareous algae and other dominant organisms. Recently, Piazzi et al. (2004) carefully studied the algal composition of coralligenous banks developing in three different subtidal habitats (islands, continental shores and offshore banks), and reported high spatial variability at reduced scales but no major differences between assemblages at a habitat level. 


\title{
MEDITERRANEAN CORALLIGENOUS ASSEMBLAGES
}

\section{Environmental factors and distribution}

\author{
Light
}

Light is probably the most important environmental factor with respect to the distribution of benthic organisms along the rocky bottoms of the continental shelf (Ballesteros 1992, Martí et al. 2004, 2005). It is also very important for the development and growth of coralligenous frameworks, as its main builders are macroalgae which need enough light to grow but which cannot withstand high levels of irradiance (Pérès \& Picard 1964, Laubier 1966).

According to Ballesteros (1992), coralligenous communities are able to develop at irradiances ranging from $1.3 \mathrm{MJ} \mathrm{m}^{-2} \mathrm{yr}^{-1}$ to $50-100 \mathrm{MJ} \mathrm{m}^{-2} \mathrm{yr}^{-1}$, that is, between $0.05 \%$ and $3 \%$ of the surface irradiance. Similar ranges are reported by Ballesteros \& Zabala (1993), who consider the lower light limit for the growth of Mediterranean corallines to be at around $0.05 \%$ of the surface irradiance (Figure 1). These values agree with those obtained by Laubier (1966) in the coralligenous communities of Banyuls, where he reported, at a depth of $32 \mathrm{~m}$, light levels of 1.8-2.6\% of surface irradiance at noon in September. However, light levels reaching different microenvironments of coralligenous communities can differ by at least two orders of magnitude. For example, Laubier (1966) reported light levels in an overhang dominated by red coral to be 17 -fold lower than those recorded in an exposed, horizontal surface. Light levels reaching small holes and cavities of coralligenous banks must be almost zero, and similar to light levels reaching the bathyal zone or the innermost part of caves.

The quality of light reaching coralligenous bottoms should also be taken into account. Most of the light belongs to the blue and green wavelengths, with green light dominating in relatively murky waters in winter and in coastal continental waters, and blue light dominating in summer and in offshore banks and islands (Ballesteros 1992) (Figure 2). Although most authors consider that light quantity is much more important than light quality in determining algal growth and primary production (e.g., Lüning 1981, Dring 1981), the absolute dominance of red algae in coralligenous assemblages close to their deepest distribution limit points to the ability of phycobilines to capture light in the 'green window' (Ballesteros 1992).

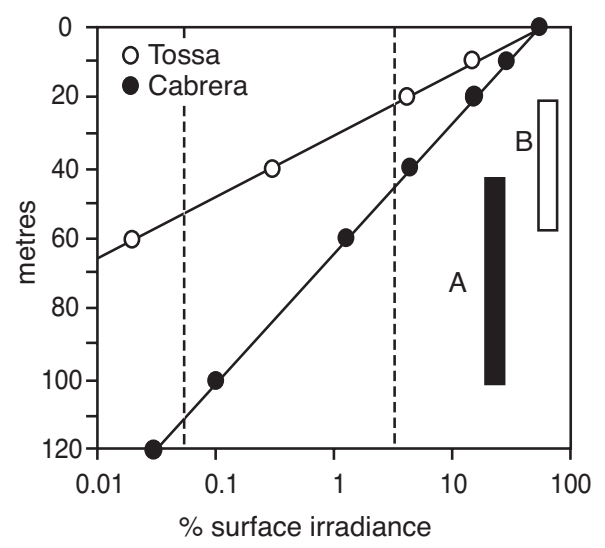

Figure 1 Light attenuation in the water column (circles) at two northwestern Mediterranean localities and depth ranges (bars) where coralligenous concretions develop over horizontal surfaces (A, Cabrera, oceanic waters; B, Tossa de Mar, continental coastal waters). (From data in Ballesteros 1992 and in Ballesteros \& Zabala 1993.) 


\section{ENRIC BALLESTEROS}
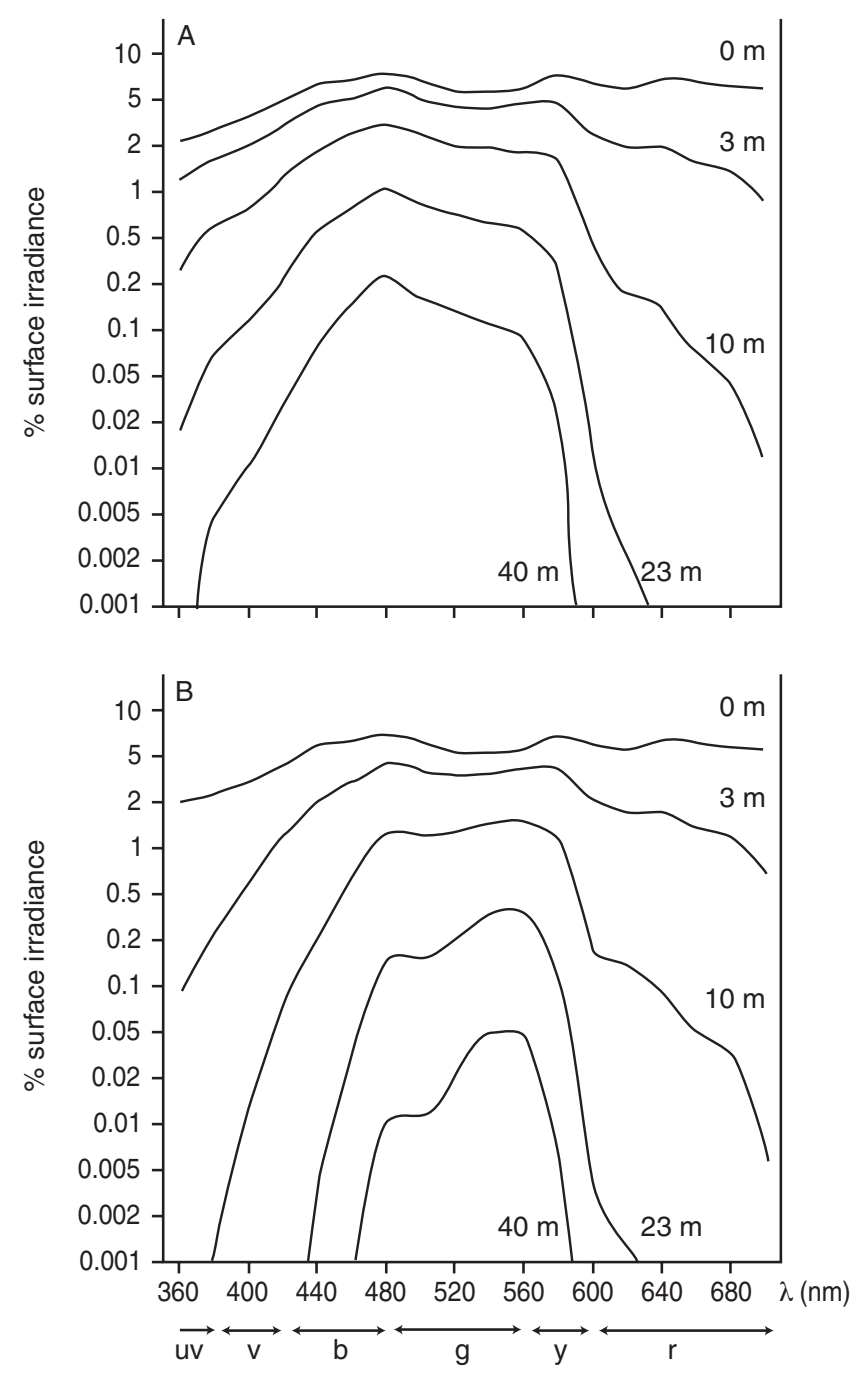

Figure 2 Distribution by wavelength (uv: ultraviolet, v: violet, b: blue, g: green, y: yellow, r: red) of submarine irradiances relative to surface irradiance for several depths in August (A) and November (B) in waters off Tossa de Mar (northwestern Mediterranean). (From Ballesteros 1992.)

\section{Nutrients, POC, DOC}

Dissolved nutrients in sea water at coralligenous depths follow the annual pattern described for coastal Mediterranean waters, with the highest values in winter and the lowest in summer. The mean annual water nitrate concentration near the coralligenous concretions at depths of 18 and $40 \mathrm{~m}$ at Tossa (northwestern Mediterranean) is around $0.6 \mu \mathrm{mol} \mathrm{l}^{-1}$, with peaks of $1.5 \mu \mathrm{mol} \mathrm{l}^{-1}$ in winter and undetectable levels in summer (Ballesteros 1992) (Figure 3). Similar values are reported for a station in Cabrera, at a depth of $50 \mathrm{~m}$ (Ballesteros \& Zabala 1993). However, these values are much lower than those reported from stations situated close to river mouths, such as the coralligenous communities around the Medes Islands, where mean annual values are close to $1 \mu \mathrm{mol} \mathrm{l}^{-1}$ (Garrabou 1997). Phosphate concentrations are much lower and are always below $0.1 \mu \mathrm{mol} \mathrm{l^{-1 }}$ at 


\section{MEDITERRANEAN CORALLIGENOUS ASSEMBLAGES}
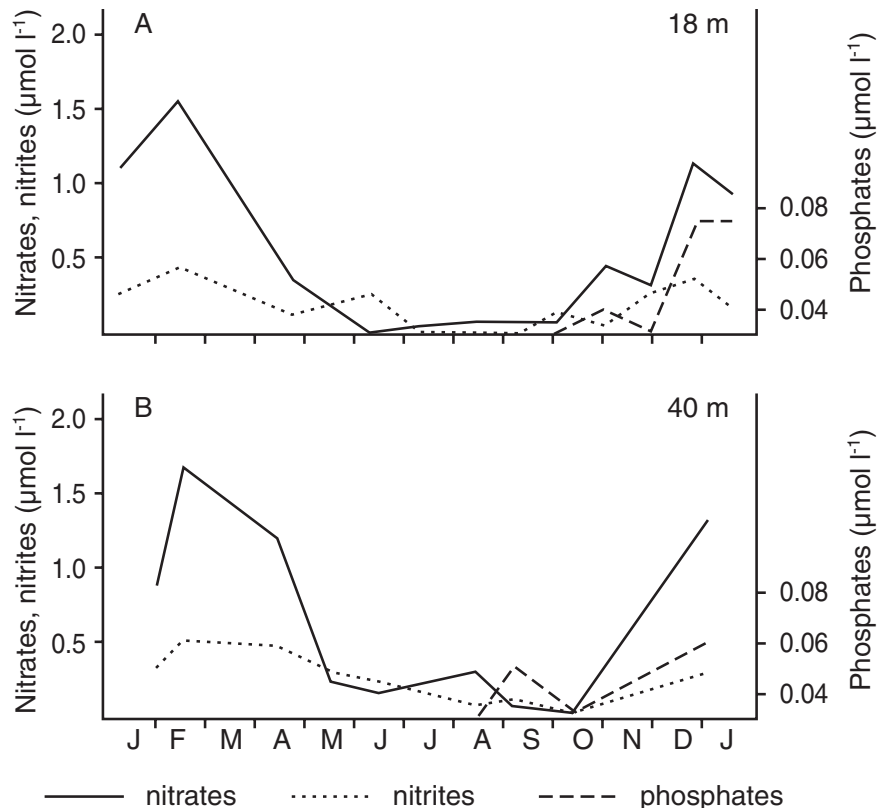

Figure 3 Monthly levels of dissolved nutrient concentrations at depths of 18 and $40 \mathrm{~m}$ in sea water close to coralligenous concretions in Tossa de Mar (January 1983-January 1984). (From Ballesteros 1992.)

Tossa and Cabrera (mean concentrations around $0.04 \mu \mathrm{mol} \mathrm{1^{-1 }}$ or lower) (Ballesteros 1992, Ballesteros \& Zabala 1993), and always below $0.2 \mu \mathrm{mol}^{-1}$ around the Medes Islands (mean concentrations around $0.13 \mu \mathrm{mol} \mathrm{1}^{-1}$ ) (Garrabou 1997) (Figure 3). Coralligenous communities seem to be adapted to these low nutrient concentrations in sea water, as increased nutrient availability greatly affects the specific composition, inhibits coralligenous construction, and increases destruction rates (Hong 1980).

Mean annual particulate organic carbon (POC) rates of $387 \mu \mathrm{g} \mathrm{C}{ }^{-1}$ are reported for the nearbottom planktonic community at a depth of $15 \mathrm{~m}$ around the Medes Islands (Ribes et al. 1999a), although winter and spring values were much higher (500-800 $\left.\mu \mathrm{g} \mathrm{C}^{-1}\right)$. Dissolved organic carbon (DOC) rates, also reported by Ribes et al. (1999a) for the same site, amount to $2560 \mu \mathrm{g} \mathrm{C} 1^{-1}$, peaking in spring and summer (Figure 4). Ribes et al. (1999a) concluded that the detrital fraction was the dominant component of total organic carbon in the near-bottom planktonic community throughout the year, which could be explained by the importance of runoff particles in the Medes Islands, but may also be due to the input of organic matter by macroalgal (and seagrass) production and the activity of benthic suspension feeders in removing microbial organisms from the plankton. However, further studies are necessary in this regard because the Medes Islands are strongly affected by continental inputs of DOC and POC, which is not usually the case for most Mediterranean coastal areas (mainly in islands or in the southern part).

\section{Water movement}

Although flowing currents predominate at depths where coralligenous communities develop (Riedl, 1966), water movement generated by waves is very significant even at depths of $50 \mathrm{~m}$ (Ballesteros \& Zabala, 1993; Garrabou, 1997) for wave heights $>1 \mathrm{~m}$. The year-round average of water motion for a coralligenous community in the Medes Islands at a depth of $25-35 \mathrm{~m}$ is $40 \mathrm{mg} \mathrm{CaSO} \mathrm{h}^{-1}$, 
ENRIC BALLESTEROS
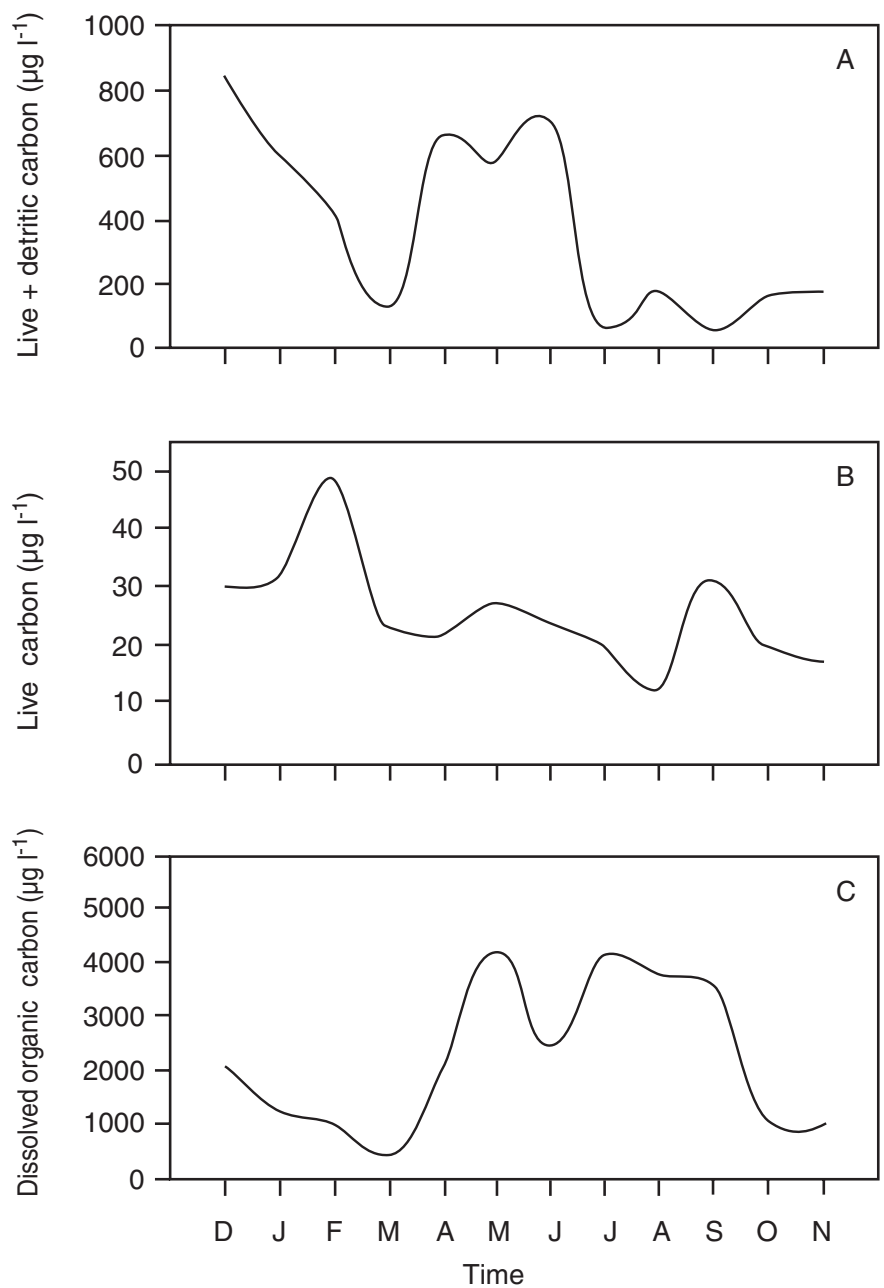

Figure 4 Monthly averages expressed as $\mu \mathrm{g} \mathrm{Cl}^{-1}$ of live and detrital carbon (A), live carbon (B) and dissolved organic carbon $(\mathrm{C})$ in waters close to coralligenous concretions around the Medes Islands (northwestern Mediterranean). (From Ribes et al. 1999a. With permission from Oxford University Press.)

that is, one order of magnitude lower than water motion at a depth of $2 \mathrm{~m}$ (Garrabou, 1997) (Figure 5). However, due to the intricate morphology of coralligenous frameworks, water movement can differ greatly between various microenvironments, in a similar way to that reported for light levels (Laubier, 1966).

\section{Temperature}

Most of the organisms living in coralligenous communities are able to support the normal seasonal temperature range characteristic of Mediterranean waters. Although Pérès \& Picard (1951) stated that coralligenous communities display a relative stenothermy, Laubier (1966) described an annual temperature range of $10-23^{\circ} \mathrm{C}$ in the coralligenous assemblages of Banyuls. Pascual \& Flos (1984) 


\section{MEDITERRANEAN CORALLIGENOUS ASSEMBLAGES}

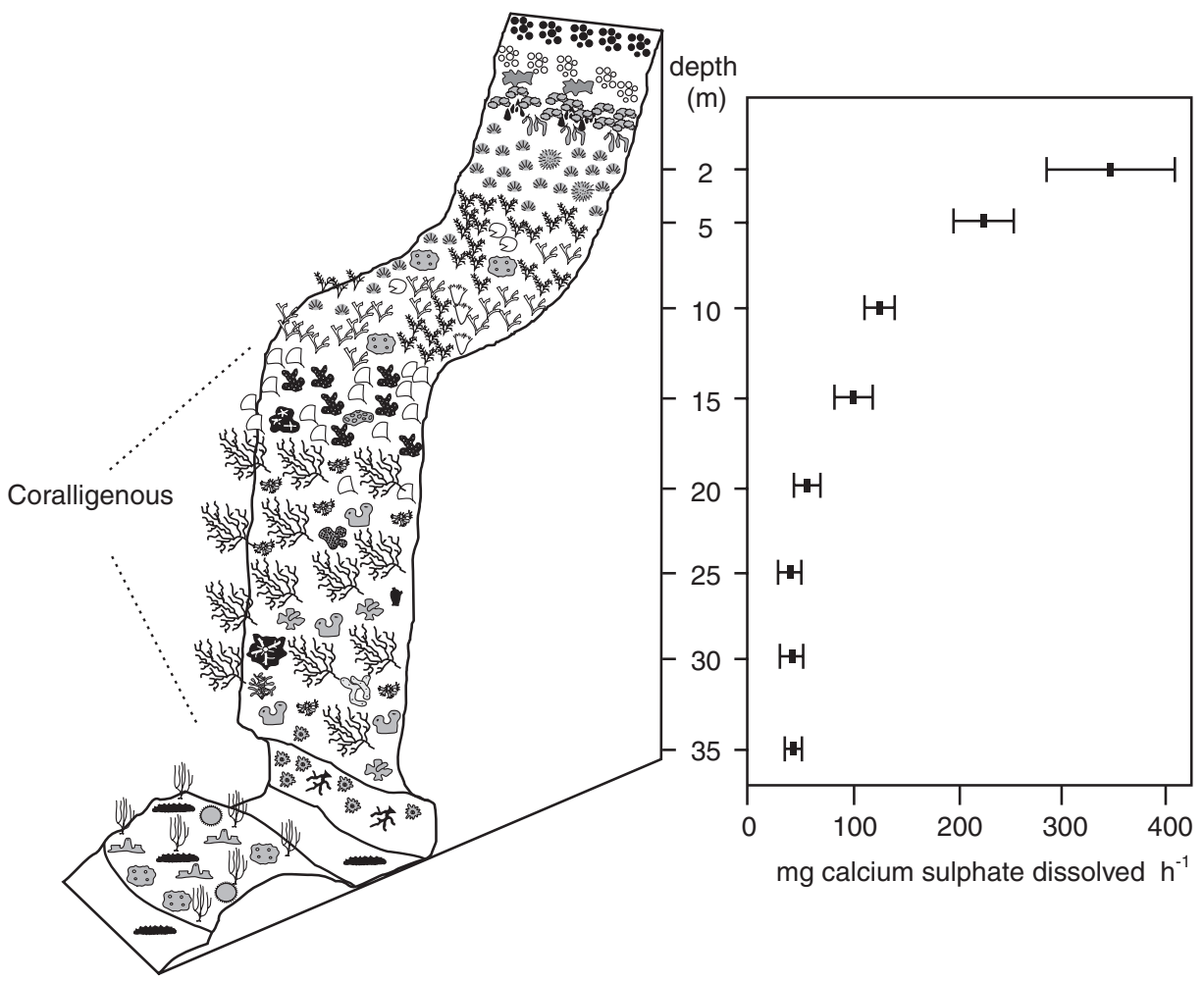

Figure 5 Year-round average in water motion attenuation (mean \pm SD) for a depth of between 0 and $35 \mathrm{~m}$ in a submarine wall at the Medes Islands. (From Garrabou 1997. With permission.)

found temperatures ranging between 12 and $20^{\circ} \mathrm{C}$ at the shallowest limit of the coralligenous communities of the Medes Islands ( $20 \mathrm{~m}$ depth), although temperatures ranged from $12-16^{\circ} \mathrm{C}$ close to their deepest limit (60 m depth) (Figure 6). Ballesteros (1992) reported more or less the same temperatures for the coralligenous assemblages developing at depths of 20 and $40 \mathrm{~m}$ at Tossa de Mar between the end of November and the end of June $\left(13-16^{\circ} \mathrm{C}\right)$, but differences of up to $9^{\circ} \mathrm{C}$ in summer, when the thermocline is situated at a depth of around $35 \mathrm{~m}$; however, peak temperatures of $22^{\circ} \mathrm{C}$ were detected at the end of August at a depth of $40 \mathrm{~m}$. In the Balearic Islands, where coralligenous communities are restricted to waters $>40 \mathrm{~m}$ deep, water temperature ranges from $14.5-17^{\circ} \mathrm{C}$ for most of the year, although occasional peaks of $22^{\circ} \mathrm{C}$ are detected at the end of October, when the thermocline is at its deepest (Ballesteros \& Zabala 1993). However, some organisms living in coralligenous assemblages from deep waters seem to be highly stenothermal, as they are never found in shallow waters. This is the case, for example, of the kelp Laminaria rodriguezii, which seems to be mainly restricted to depths $>70 \mathrm{~m}$ and is seldom found between 50 and $70 \mathrm{~m}$, except for in seamounts or upwelling systems (Ballesteros, unpublished data). Moreover, recent (1999) large-scale mortality events of benthic suspension feeders thriving in coralligenous communities have been attributed to unusually long-lasting periods of high temperatures during summer (Perez et al. 2000; Romano et al. 2000), although the ultimate cause of these mortalities remains unclear (possible causes include high temperatures, low food availability, pathogens and physiological stress). 


\section{ENRIC BALLESTEROS}

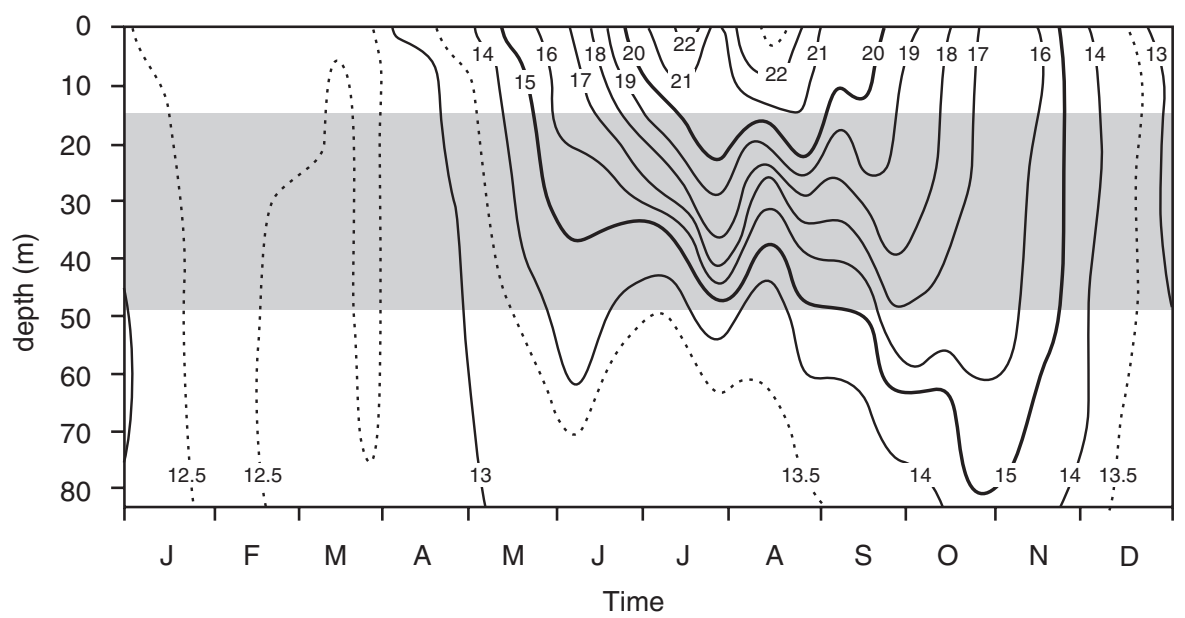

Figure 6 Average seawater temperatures for a depth of between 0 and $80 \mathrm{~m}$ off the Medes Islands (July 1973-December 1977). Shaded area corresponds to depth of coralligenous outcrops. (From Pascual \& Flos, 1984. With permission.)

\section{Salinity}

The relatively shallow and coastal coralligenous communities of Banyuls and the Medes Islands experience salinity ranges between 37 and 38 (Laubier 1966, Pascual \& Flos 1984), although salinity variations for coralligenous assemblages from insular areas should be lower.

\section{Geographical distribution}

Coralligenous buildups are common all around the Mediterranean coasts, with the possible exception of those of Lebanon and Israel (Laborel, 1987). According to Laborel (1961), the best developed formations are those found in the Aegean Sea, although the most widely studied banks are those of the northwestern Mediterranean; therefore, most of the data presented here come from this area.

\section{Depth distribution}

The minimal depth for the formation of coralligenous frameworks depends on the amount of irradiance reaching the sea bottom. On vertical slopes in the area around Marseilles this minimal depth reaches $20 \mathrm{~m}$, but it is much lower in other zones like the Gulf of Fos, where coralligenous communities are able to grow in shallower waters $(12 \mathrm{~m})$ because of the high turbidity of the water related to the Rhône mouth. This minimal depth is displaced to deeper waters in insular areas like Corsica or the Balearic Islands, where water transparency is very high (Ballesteros \& Zabala 1993). However, coralligenous frameworks can appear in very shallow waters if light conditions are dim enough to allow a significant development of coralline algae (Laborel 1987, Sartoretto 1994) and they may even occur in the clearest waters like those around Cabrera, where they can be found at a depth of only $10 \mathrm{~m}$ in a cave entrance (Martí et al. 2004).

The depth distribution of coralligenous assemblages in subhorizontal to horizontal bottoms for different Mediterranean areas is summarised in Table 1. 


\section{MEDITERRANEAN CORALLIGENOUS ASSEMBLAGES}

Table 1 Depth intervals for the distribution of coralligenous outcrops in different Mediterranean areas

\begin{tabular}{lcl}
\hline Region & Depth $(\mathrm{m})$ & Reference \\
\hline Banyuls & $20-40$ & Feldmann 1937, Laubier 1966 \\
Marseilles & $20-50$ & Laborel 1961, Hong 1980 \\
Medes Islands & $20-55$ & Gili \& Ros 1984 \\
Tossa de Mar & $20-60$ & Ballesteros 1992 \\
Naples & $45-70$ & Bacci 1947 \\
Cabrera & $50-100$ & Ballesteros et al. 1993 \\
Corsica & $60-80$ & Laborel 1961 \\
Northeastern Mediterranean & $70-90$ & Laborel 1961 \\
Aegean Islands & $90-110$ & Laborel 1961 \\
Siculo-Tunisian area & $90-120$ & Laborel 1961 \\
Southeastern Mediterranean & $100-120$ & Laborel 1961 \\
\hline
\end{tabular}

\section{Structure}

\section{Coralligenous types: structure and habitats}

The morphology and inner structure of coralligenous frameworks depends greatly on depth, topography, and the nature of prevailing algal builders (Laborel 1961). Two main morphologies can be distinguished (Pérès \& Picard 1964, Laborel 1987): banks and rims.

Banks are flat frameworks with a variable thickness that ranges from 0.5 to several (3-4) $\mathrm{m}$. They are mainly built over more or less horizontal substrata, and have a very cavernous structure (numerous holes, Laborel 1987) that often leads to a very typical morphology (it has been compared to Gruyère cheese) (Figure 7A). These banks are sometimes surrounded by sedimentary substrata, and Pérès \& Picard (1952) argued that they developed from the coalescence of rhodoliths or maërl (coralligène de plateau). However, it is highly probable that these frameworks have almost always grown upon rocky outcrops (Got \& Laubier 1968, Laborel 1987) (Figure 7B).

Rims develop in the outer part of marine caves and on vertical cliffs, usually in shallower waters than banks. The thickness of rims is also variable and ranges from $20-25 \mathrm{~cm}$ to $>2 \mathrm{~m}$; thickness increases from shallow to deep waters (Laborel 1987) (Figure 7C).

In shallow water the main algal builder is Mesophyllum alternans, which builds flat or slightly rounded banks or rims with a foliaceous structure. As the water deepens, other corallines (Lithophyllum frondosum, L. cabiochae, Neogoniolithon mamillosum) become important builders. Shallow water banks are generally covered with populations of green algae Halimeda tuna and Flabellia petiolata (Lithophyllo-Halimedetum tunae), which can be so dense that they hide the calcareous algae. However, at greater depths the density of these erect algae decreases and corallines dominate the community (Rodriguezelletum strafforellii).

Holes and cavities within the coralligenous structure always sustain a complex community dominated by suspension feeders (sponges, hydrozoans, anthozoans, bryozoans, serpulids, molluscs, tunicates) (Figure 7D). The smallest crevices and interstices of the coralligenous buildup have an extraordinarily rich and diverse vagile endofauna of polychaetes and crustaceans, while many attached or unattached animals cover the main macroalgae and macrofauna, swarm everywhere, from the surface to the cavities or inside the main organisms, and thrive in the small patches of sediment retained by the framework. 


\section{ENRIC BALLESTEROS}
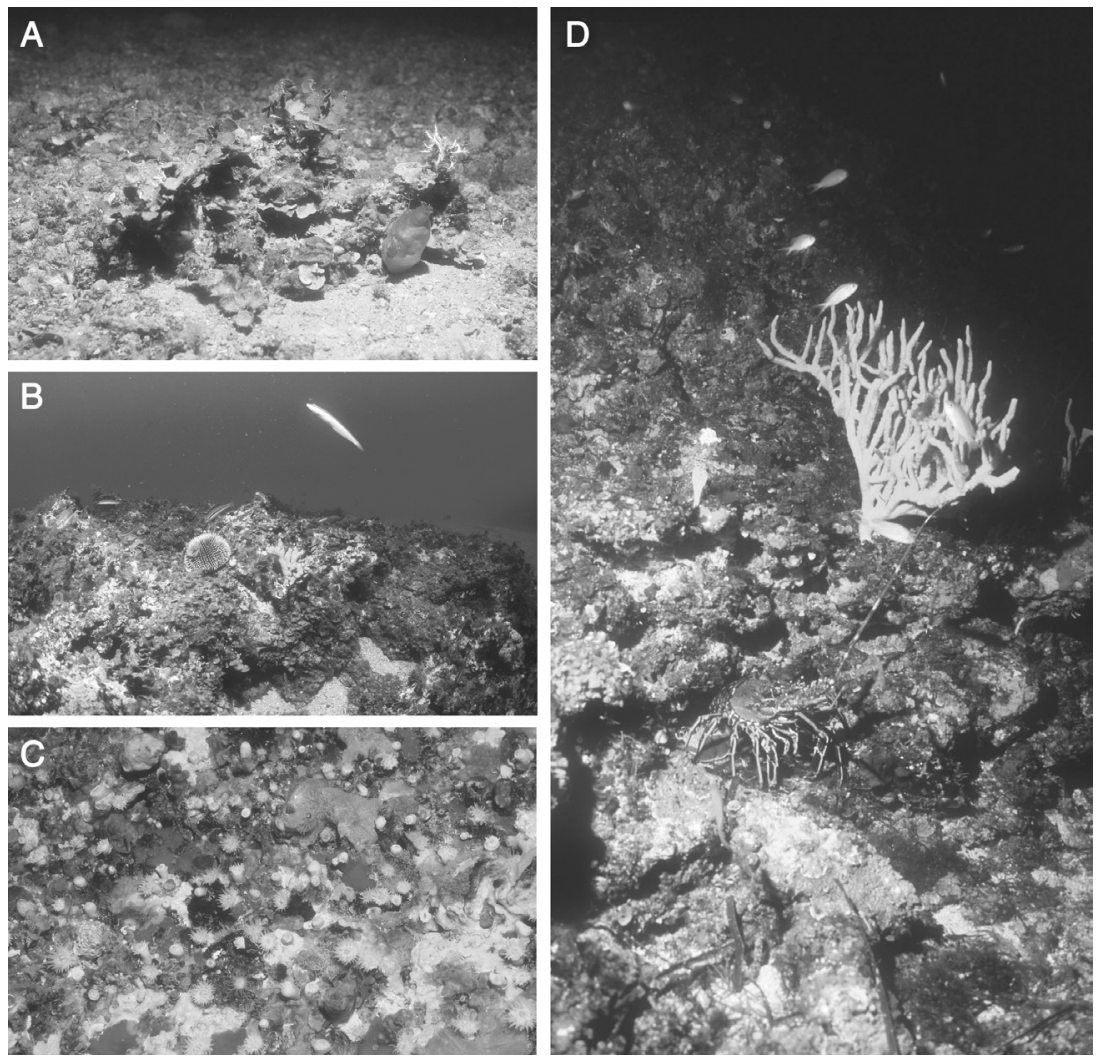

Figure 7 (See also Colour Figure 7 in the insert following page 276.) Types and habitats in coralligenous outcrops. (A) small coralligenous accretion apparently developed from the coalescence of rhodoliths (Tossa de Mar, NE Spain, 40 m depth); (B) coralligenous bank grown upon a rocky outcrop (Tossa de Mar, NE Spain, $25 \mathrm{~m}$ depth); (C) community dominated by suspension feeders in a coralligenous cavity (Cabrera, Balearic Islands, $52 \mathrm{~m}$ depth); (D) coralligenous rim on a vertical cliff (Gargalo, Corsica, $48 \mathrm{~m}$ depth). (Photos by the author.)

According to Hong (1982) four different categories of invertebrates can be distinguished with respect to their position and ecological significance in the coralligenous structure:

1. Fauna contributing to buildup, which help develop and consolidate the framework created by the calcareous algae. Several bryozoans, polychaetes (serpulids), corals and sponges constitute this category. They include $24 \%$ of the total species number.

2. Cryptofauna colonising the small holes and crevices of the coralligenous structure. They represent around $7 \%$ of the species, including different molluscs, crustaceans and polychaetes.

3. Epifauna (living over the concretions) and endofauna (living inside the sediments retained by the buildup), which represent a great number of species (nearly $67 \%$ ).

4. Eroding species, accounting for only around $1 \%$.

\section{Algal builders}

Coralline algae are the main coralligenous builders (Laborel 1961, Laubier 1966, Sartoretto 1996). The taxonomy of this group of algae is very difficult to determine and the nomenclature of the 


\section{MEDITERRANEAN CORALLIGENOUS ASSEMBLAGES}
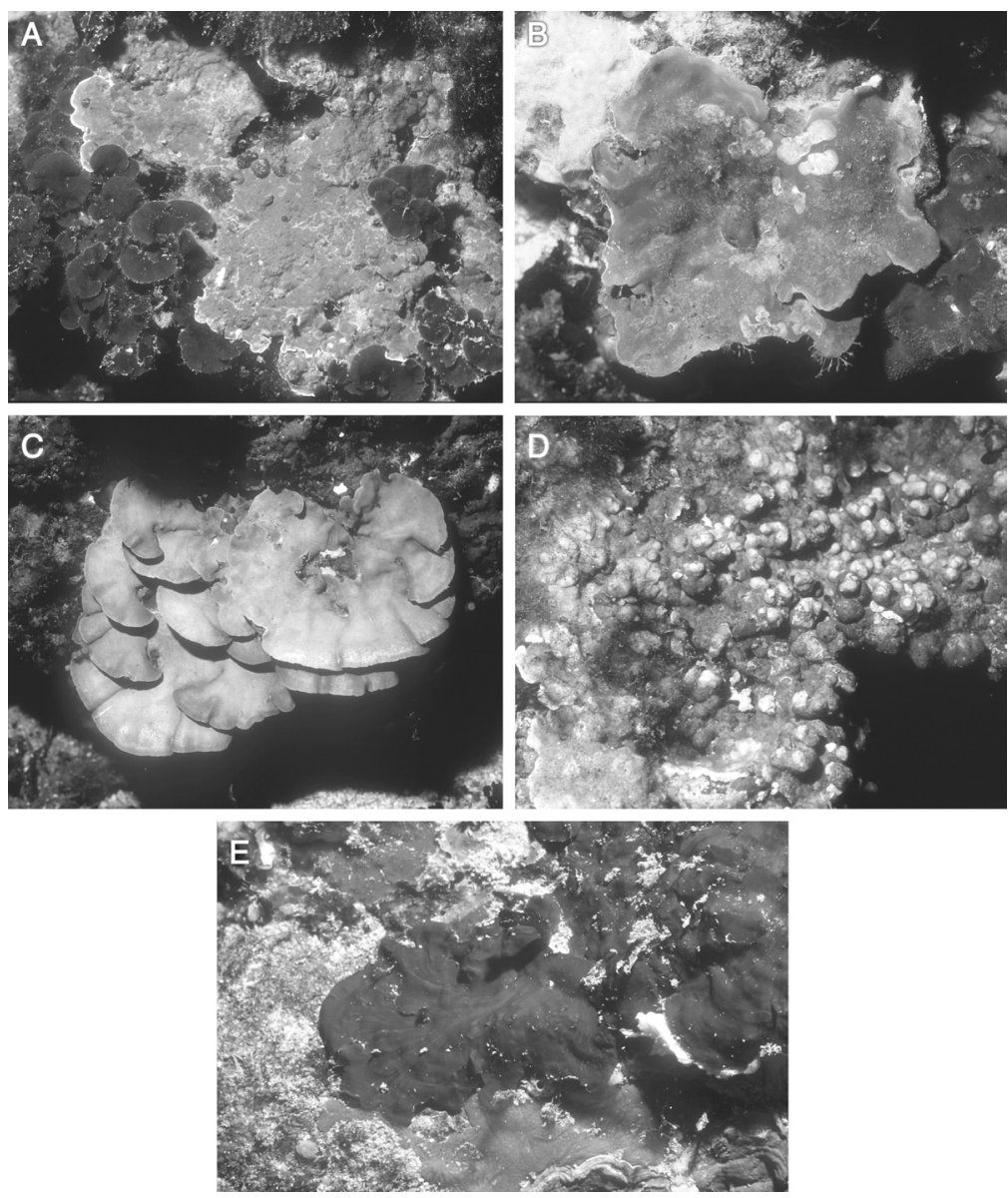

Figure 8 (See also Colour Figure 8 in the insert.) Main red algal building species in coralligenous frameworks. (A) Mesophyllum alternans; (B) Lithophyllum frondosum; (C) Lithophyllum cabiochae; (D) Neogoniolithon mamillosum; (E) Peyssonnelia rosa-marina. (Photos by the author.)

species is constantly changing. Due to their great importance in the construction of coralligenous frameworks several issues regarding the taxonomic status and current nomenclature of the main species are considered here.

The main algal building species, according to Sartoretto (1996) and several other authors (e.g., Feldmann 1937, Pérès \& Picard 1964, Boudouresque 1970, Hong 1980, Ballesteros 1991b), has repeatedly been identified as Mesophyllum lichenoides (Ellis) Lemoine. However, Cabioch \& Mendoza (1998) reported the most common species of the genus Mesophyllum growing in coralligenous assemblages to be a different species and named it Mesophyllum alternans (Foslie) Cabioch \& Mendoza (Figure 8A). Although present in the Mediterranean Sea, M. lichenoides does not seem to contribute to coralligenous buildup (Cabioch \& Mendoza 1998). Therefore, it is likely that some or most of the reports of $M$. lichenoides as a coralligenous builder actually refer to M. alternans (Cabioch \& Mendoza, 1998) (Figure 8A).

Pseudolithophyllum expansum (sensu Lemoine) has been identified by most authors as being the second most common coralline alga in coralligenous concretions. However, Boudouresque \& Verlaque (1978) identified another species, similar to P. expansum, and described it as $P$. cabiochae. Later, studies by Woelkerling (1983), Athanasiadis (1987), Woerkerling et al. (1993) and Furnari 


\section{ENRIC BALLESTEROS}

et al. (1996) shed some light (but also added further confusion) regarding the name to be applied to the alga called $P$. expansum and/or $P$. cabiochae by Mediterranean phycologists and marine biologists. The last review by Athanasiadis (1999a) suggested that Pseudolithophyllum should not be regarded as a different genus to Lithophyllum and that the two species growing in coralligenous communities should be named Lithophyllum stictaeforme (Areschoug) Hauck [= Lithophyllum frondosum (Dufour) Furnari, Cormaci \& Alongi; = Pseudolithophyllum expansum (Philippi) Lemoine; = Lithophyllum expansum sensu Lemoine] (Figure 8B) and Lithophyllum cabiochae (Boudouresque \& Verlaque) Athanasiadis (Figure 8C). However, according to Marc Verlaque (personal communication), L. stictaeforme and $L$. frondosum are not synonyms and the species usually reported as Pseudolithophyllum expansum by Mediterranean phycologists should be named Lithophyllum frondosum.

Moreover, Woelkerling (1983) recognised the lectotype of Lithophyllum expansum Philippi (non Lemoine) as a Mesophyllum and considered it to be a heterotypic synonym of M. lichenoides. However, a recent study by Cabioch \& Mendoza (2003) showed that the lectotype of Lithophyllum expansum Philippi is specifically different from Mesophyllum lichenoides, M. alternans and other Mediterranean species of this genus. They named it Mesophyllum expansum (Philippi) Cabioch and Mendoza and it corresponds to the taxa usually identified as Mesophyllum lichenoides var. agariciformis (Pallas) Harvey by Mediterranean phycologists. As a result of all this confusion it is not possible to determine the extent to which $M$. expansum contributes to coralligenous buildup, although it is likely to make a significant contribution, at least in some places. Another species, Mesophyllum macroblastum (Foslie) Adey, has been reported for the coralligenous frameworks in Corsica (Cabioch \& Mendoza 2003), and a fifth species (Mesophyllum macedonis Athanasiadis) (Athanasiadis 1999b) may also be present in the coralligenous frameworks of the Aegean Sea. According to Marc Verlaque (personal communication), three species of the genus Mesophyllum coexist in the coralligenous communities off Marseille (M. alternans, M. expansum, M. macroblastum), suggesting a much greater biodiversity of coralligenous coralline algae than expected.

The alga identified by Feldmann (1937) as Lithophyllum hauckii (Rothpletz) Lemoine, a very common coralline in the coralligenous buildups of the Banyuls region, should be named Neogoniolithon mamillosum (Hauck) Setchell \& Mason (Hamel \& Lemoine 1953, Bressan \& BabbiniBenussi 1996) [= Spongites mamillosa (Hauck) Ballesteros] (Figure 8D).

Although not a coralline alga, it should also be pointed out that authors prior to 1975 identified the calcareous Peyssonnelia growing in coralligenous communities as being Peyssonnelia polymorpha (Zanardini) Schmitz. Boudouresque \& Denizot (1975) described a similar species, Peyssonnelia rosa-marina (Figure 8E), that is more common than P. polymorpha and which also contributes to coralligenous frameworks. Therefore, reports of $P$. polymorpha prior to the description of $P$. rosa marina should probably be regarded as referring to this latter species or to both entities.

Feldmann (1937) identified the four main calcareous algae responsible for the coralligenous frameworks in the region of Banyuls: Lithophyllum frondosum (as Pseudolithophyllum expansum), Neogoniolithon mamillosum (as Lithophyllum hauckii), Mesophyllum alternans (as M. lichenoides) and Peyssonnelia rosa-marina f. saxicola (as P. polymorpha). The same species have also been reported for coralligenous frameworks studied in several areas close to the Gulf of Lions (e.g., Boudouresque 1973, Ballesteros 1992). It seems that these species are almost always the same, with the possible exception of Lithophyllum frondosum which seems to be replaced by L. cabiochae in several areas of the Mediterranean that are warmer than the Gulf of Lions (e.g., Corsica, Balearic Islands, the eastern Mediterranean).

Hong (1980) reports three species as being the main coralligenous builders in the region of Marseilles: Lithophyllum cabiochae, Mesophyllum alternans (?) and Neogoniolithon mamillosum. Peyssonnelia rosa-marina is also very abundant. Other calcareous species contributing to buildup are Archaeolithothamnion mediterraneum, Lithothamnion sonderi (?) and Peyssonnelia polymorpha. 


\section{MEDITERRANEAN CORALLIGENOUS ASSEMBLAGES}

According to Sartoretto et al. (1996), Mesophyllum alternans (as M. lichenoides) is the main algal building species for both ancient and recent coralligenous constructions in the northwestern Mediterranean. Mesophyllum alternans is a highly tolerant species in terms of light, temperature and hydrodynamism, and is currently the dominant species in shallow waters. In some areas, Peyssonnelia rosa-marina and $P$. polymorpha may also be the dominant species, and form a very cavernous, highly bioeroded coralligenous framework. In deep waters Lithophyllum cabiochae is the main calcareous alga in the region of Marseilles and Corsica, but its cover can vary from one geographical area to another. For example, the encrusting algal cover in deep-water coralligenous frameworks in Marseilles is limited to a few isolated small living thalli that seem insufficient to allow current renewal of the coralligenous construction. In contrast, these deep frameworks are luxuriant in Corsica, as evidenced by the accumulation of living thalli of L. cabiochae.

The identification of the species present in the algal framework of coralligenous blocks from 7700 years ago to the present has shown that no species changes have occurred (Sartoretto et al. 1996). The study by Sartoretto et al. (1996) in the Marseilles region and Corsica identified five Corallinaceae and one Peyssonneliaceae: the nongeniculate corallines Mesophyllum alternans (as M. lichenoides), Lithophyllum sp. (as Titanoderma sp., probably Lithophyllum pustulatum v. confinis), Lithophyllum cabiochae-frondosum (discrimination between L. cabiochae and L. frondosum is uncertain in fossil material), Lithothamnion sp., the geniculate coralline alga Amphiroa verruculosa, and, finally, Peyssonnelia sp. Mesophyllum alternans is also the main algal builder in the coralligenous frameworks of the Mediterranean Pyrenees (Bosence, 1985), along with Lithophyllum and Titanoderma (quoted as Pseudolithophyllum and Tenarea in Bosence's paper). Peyssonnelia polymorpha and $P$. rosa-marina f. saxicola may also be abundant in the coralligenous frameworks of the Mediterranean Pyrenees, the northeast coast of Spain, and the Balearic Islands (Bosence 1985, Ballesteros 1992, Ballesteros et al. 1993). However, even if Peyssonnelia is abundant as a living encrusting alga, it is almost completely absent from the fossil record (Bosence 1985, Sartoretto 1996). Carbonate content of the Peyssonnelia species is lower than the average carbonate content in corallines (Laubier 1966, Ballesteros 1992), and calcification in the form of aragonite rather than calcite prevents a good fossilization of these species (James et al. 1988). However, these and other species of Peyssonnelia usually have a basal layer of aragonite that may contribute to the consolidation of coralligenous frameworks when mixed with the physico-chemical precipitations of $\mathrm{CaCO}_{3}$ (Sartoretto 1996).

\section{Animal builders}

Coralligenous animal builders have been studied in the Marseilles region (Hong 1980) where 124 species contribute to the frameworks, and account for around $19 \%$ of the total number of species reported. The most abundant animal group are the bryozoans, accounting for $62 \%$ of species, followed by the serpulid polychaetes with $23.4 \%$. Minor contributors are the cnidarians (4\%), molluscs (4\%), sponges (4\%), crustaceans (1.6\%) and foraminiferans (0.8\%). However, Laborel (1987) considers the foraminiferan Miniacina miniacea (Figure 9A) to be the most important animal builder. Hong (1980) distinguished three different types of animal builders: those contributing directly to the framework, and which are relatively large; those with a reduced builder activity due to their small size; and those which agglomerate carbonate particles. The first group includes the bryozoans Schizomavella spp., Onychocella marioni, Cribilaria radiata, Pentapora fascialis, Enthalophoroecia deflexa, Celleporina caminata, Myriapora truncata, Brodiella armata and Turbicellepora coronopus (Figures 9B,C), several serpulids (Serpula vermicularis, S. concharum, Spirobranchus polytrema) (Figure 9D), the molluscs Vermetus sp., Serpulorbis arenarius and Clavagella melitensis, and the scleractinians Hoplangia durotrix, Leptopsammia pruvoti, Caryophyllia inornata and C. smithii (Figure 9E). Among the second group, Hong (1980) reports some small bryozoans 


\section{ENRIC BALLESTEROS}
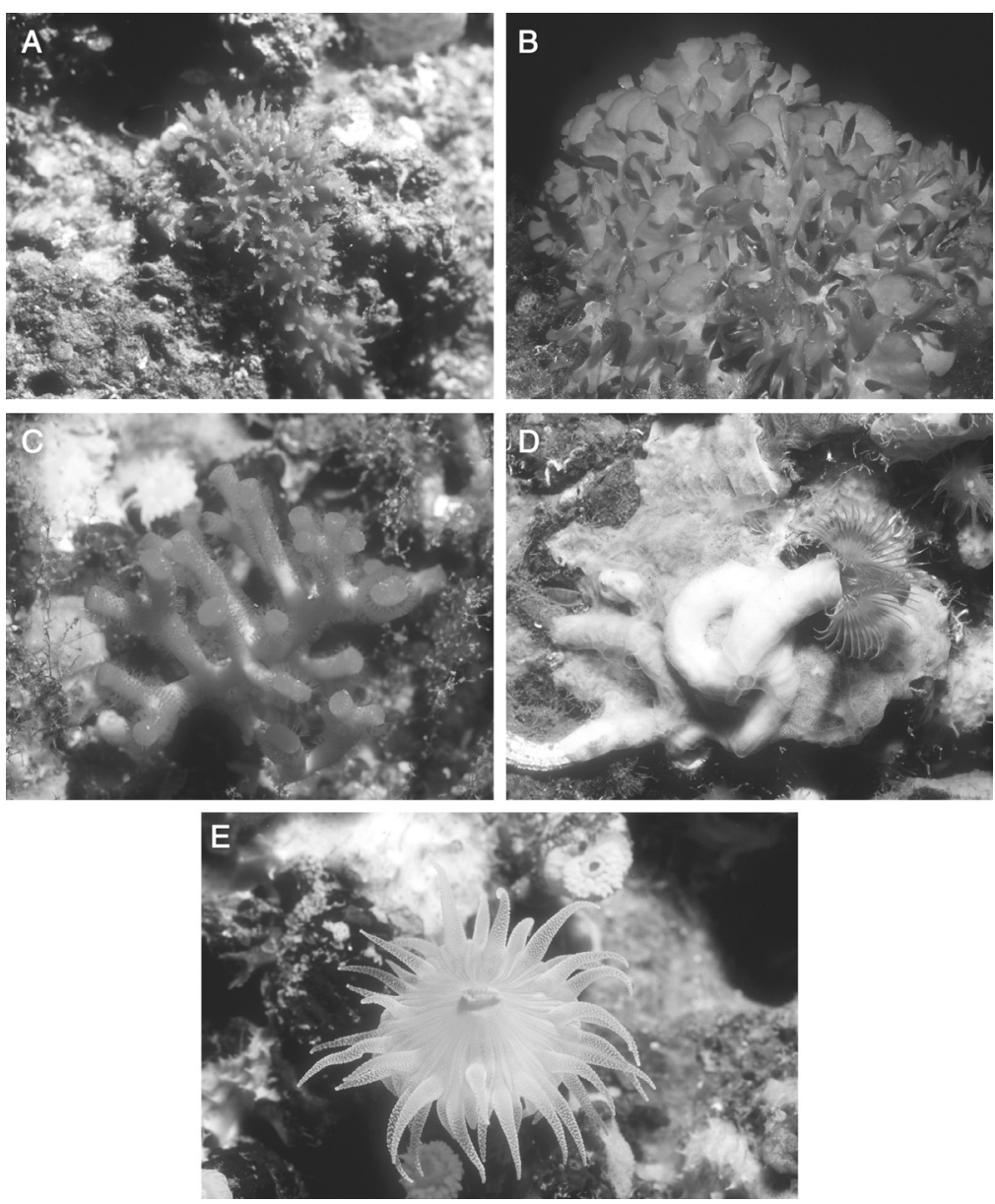

Figure 9 (See also Colour Figure 9 in the insert.) Some animal building species in coralligenous frameworks. (A) Miniacina miniacea; (B) Pentapora fascialis; (C) Myriapora truncata; (D) Serpula vermicularis; (E) Leptopsammia pruvoti. (Photos by the author.)

such as Crassimarginatella maderensis and Mollia patellaria, serpulids like Hydroides spp., Filogranula spp., and Spirorbis spp., the cirripedes Verruca strömia and Balanus perforatus, and the foraminiferan Miniacina miniacea. In terms of the 'agglomerative' animals, he reports sponges such as Geodia spp., Spongia virgultosa and Faciospongia cavernosa, the bryozoans Beania spp., and the alcyonarian Epizoanthus arenaceus.

\section{Bioeroders}

Feldmann (1937) described the abundance of several organisms that erode calcareous concretions, in particular the excavating sponge Cliona viridis (Figure 10A), the bivalve Lithophaga lithophaga and several annelids. Hong (1980) listed 11 bioeroders in the coralligenous communities of Marseilles: four species of sponges of the genus Cliona, three species of molluscs, two species of polychaetes of the genus Polydora and two sipunculids. According to Sartoretto (1996), the organisms that erode coralligenous frameworks are similar to those eroding other marine bioherms such 


\section{MEDITERRANEAN CORALLIGENOUS ASSEMBLAGES}
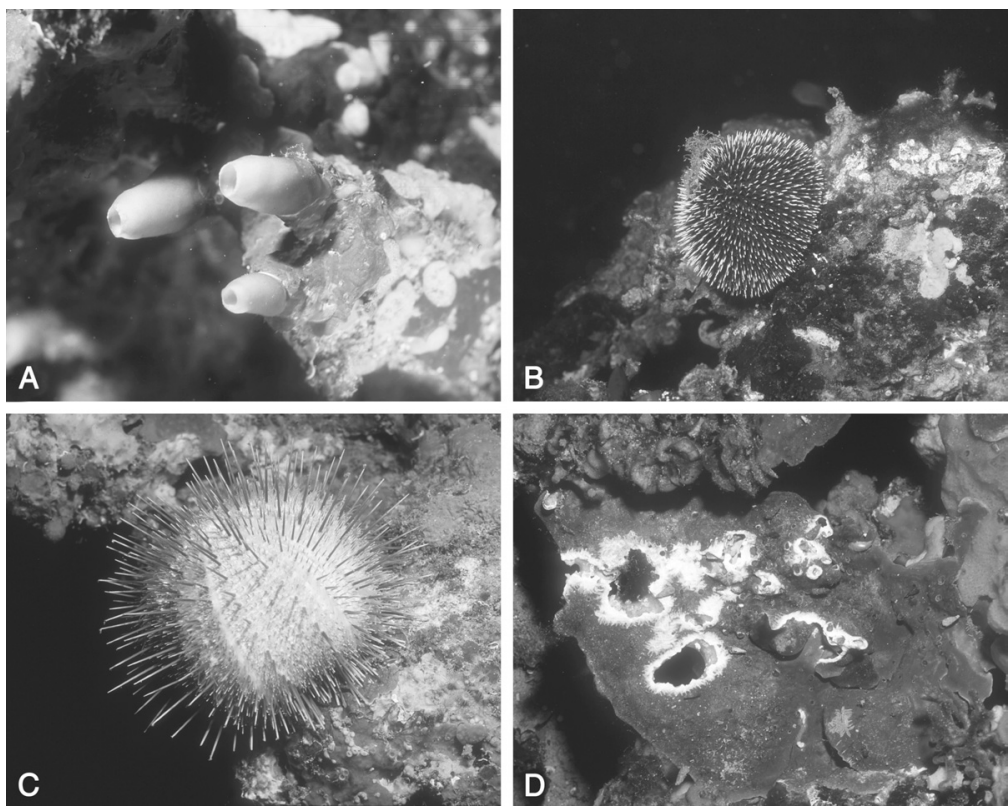

Figure 10 (See also Colour Figure 10 in the insert.) Bioeroders in coralligenous frameworks. (A) Cliona viridis; (B) Sphaerechinus granularis; (C) Echinus melo; (D) browsing marks of Sphaerechinus granularis over Lithophyllum frondosum. (Photos by the author.)

as the trottoir of Lithophyllum byssoides or the coral reefs. Three types of eroding organisms can be distinguished: browsers, microborers and macroborers.

The only browsers in the coralligenous concretions are sea urchins (Laubier 1966), because the only important Mediterranean fish grazing on algae (Sarpa salpa) do not usually thrive in coralligenous communities. Sphaerechinus granularis (Figure 10B,D) is an important biological agent that substantially erodes coralligenous concretions, although local variations in sea urchin abundance and individual size greatly influence the amount of calcium carbonate eroded annually. Another sea urchin commonly found in coralligenous communities is Echinus melo (Figure 10C). The proportion of calcareous algae in its digestive content ranges from $18-50 \%$ of the total (Sartoretto 1996) and it preys mainly on sponges, bryozoans and serpulid polychaetes. Given the low densities of this sea urchin in coralligenous communities (1-3 individuals in $25 \mathrm{~m}^{2}$ ), Sartoretto (1996) concludes that the bioerosional role of E. melo is very limited.

Microborers include blue-green algae (cyanobacteria), green algae and fungi (Hong 1980). Three green algae (Ostreobium quekettii, Phaeophila sp. and Eugomontea sp.) and four cyanobacteria (Plectonema tenebrans, Mastigocoleus testarum, Hyella caespitosa and Calothrix sp.), together with some unidentified fungi, seem to be the main microborers in coralligenous communities. Diversity is higher in shallow waters, whereas, according to colonisation studies conducted by Sartoretto (1998), it is restricted to only one species (Ostreobium) in deep waters (>60 m).

Macroborers comprise molluscs (Lithophaga lithophaga, Gastrochaena dubia, Petricola lithophaga, Hyatella arctica), sipunculids (Aspidosiphon mülleri, Phascolosoma granulatum), polychaetes (Dipolydora spp., Dodecaceria concharum) and several excavating sponges (Sartoretto 1996, Martin \& Britayev 1998). Among perforating sponges commonly found in coralligenous communities, some of them excavate mainly in Corallium rubrum and other calcareous cnidarians ( $A k a$ labyrinthica, Scantilletta levispira, Dotona pulchella spp. mediterranea, Cliona janitrix), whereas others, such as Pione vastifica, Cliona celata, C. amplicavata, $C$. schmidtii and $C$. viridis can be 


\section{ENRIC BALLESTEROS}

found in a wide range of calcareous substrata (coralline algae, bivalves, madreporids, etc.) (Rosell \& Uriz 2002). Cliona viridis is the most powerful destructive sponge of calcareous substrata (Rosell et al. 1999), and is the most abundant excavating sponge in coralligenous communities (Uriz et al. 1992a). The encrusting sponges and the Sipunculida become more abundant in polluted coralligenous environments (Hong 1983).

\section{Assemblages}

The final result of the builders and eroders of coralligenous concretions is a very complex structure, in which several microhabitats can be distinguished (Figure 11). Environmental factors (e.g., light, water movement and sedimentation rates) can vary by one to two orders of magnitude in parts of the same concretion situated as close as one metre from each other. This great environmental heterogeneity allows several different assemblages to coexist in a reduced space. For practical purposes those situated in open waters (from horizontal to almost vertical surfaces) are distinguished here from those situated in overhangs and cavities. The assemblages of macroborers are not discussed because the only available data have already been commented on, nor are the assemblages thriving in the patches of sediment between or inside coralligenous frameworks because there are no quantitative data on them.

Algae, both encrusting corallines and green algae, usually dominate in horizontal to subhorizontal surfaces (Figure 12), although their abundance decreases with depth or in dim light. Phycologists have distinguished two main communities according to the light levels reaching coralligenous frameworks. In shallower waters Mesophyllum alternans usually dominates in the basal layer and Halimeda tuna in the upper stratum, with an important coverage of other algae (Peyssonnelia spp., Flabellia petiolata) (Figure 13A). This plant association has received the name of LithophylloHalimedetum tunae, and has been described in detail by Ballesteros (1991b). Algal biomass ranges between 1200 and $2100 \mathrm{~g}$ dry weight $(\mathrm{dw}) \mathrm{m}^{-2}$, while percent cover ranges from $180-400 \%$. The number of species is very high (average of 76 species in $1024 \mathrm{~cm}^{2}$ ) and average diversity is 2.5 bits ind $^{-1}$. Its bathymetric distribution ranges from a depth of $12-15 \mathrm{~m}$ to $30-35 \mathrm{~m}$ in the Gulf of Lions, but it can reach depths below $50 \mathrm{~m}$ in the clear waters of seamounts and insular territories of the western and eastern Mediterranean. This association develops at irradiances ranging from around

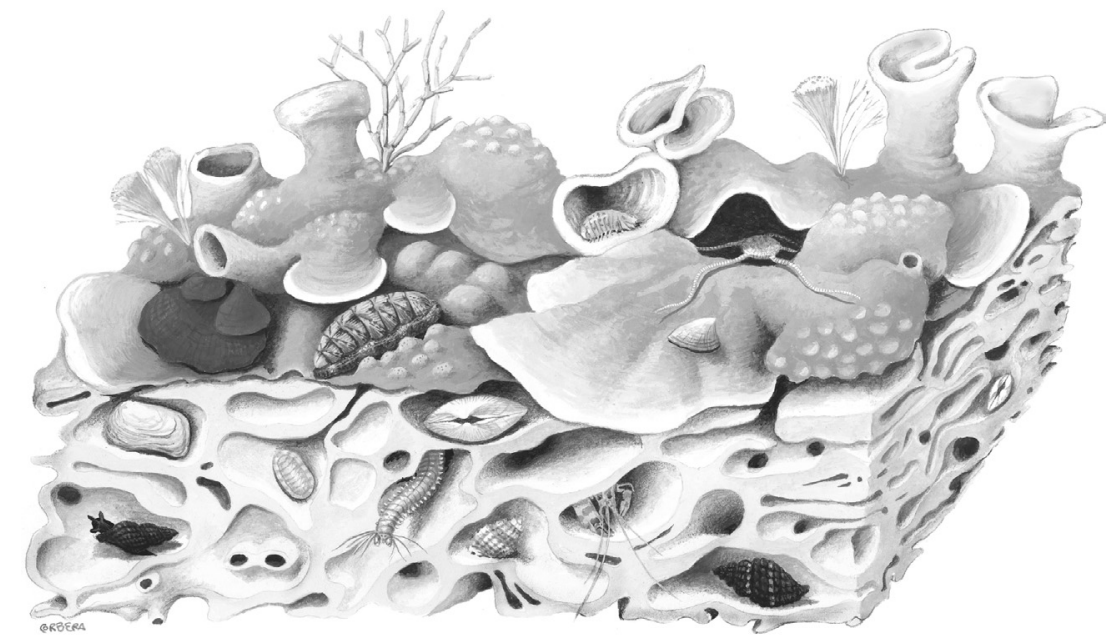

Figure 11 (See also Colour Figure 11 in the insert.) Diagrammatic section of a coralligenous bank, showing the high small-scale environmental heterogeneity and the different microhabitats. (Drawing by J. Corbera.) 


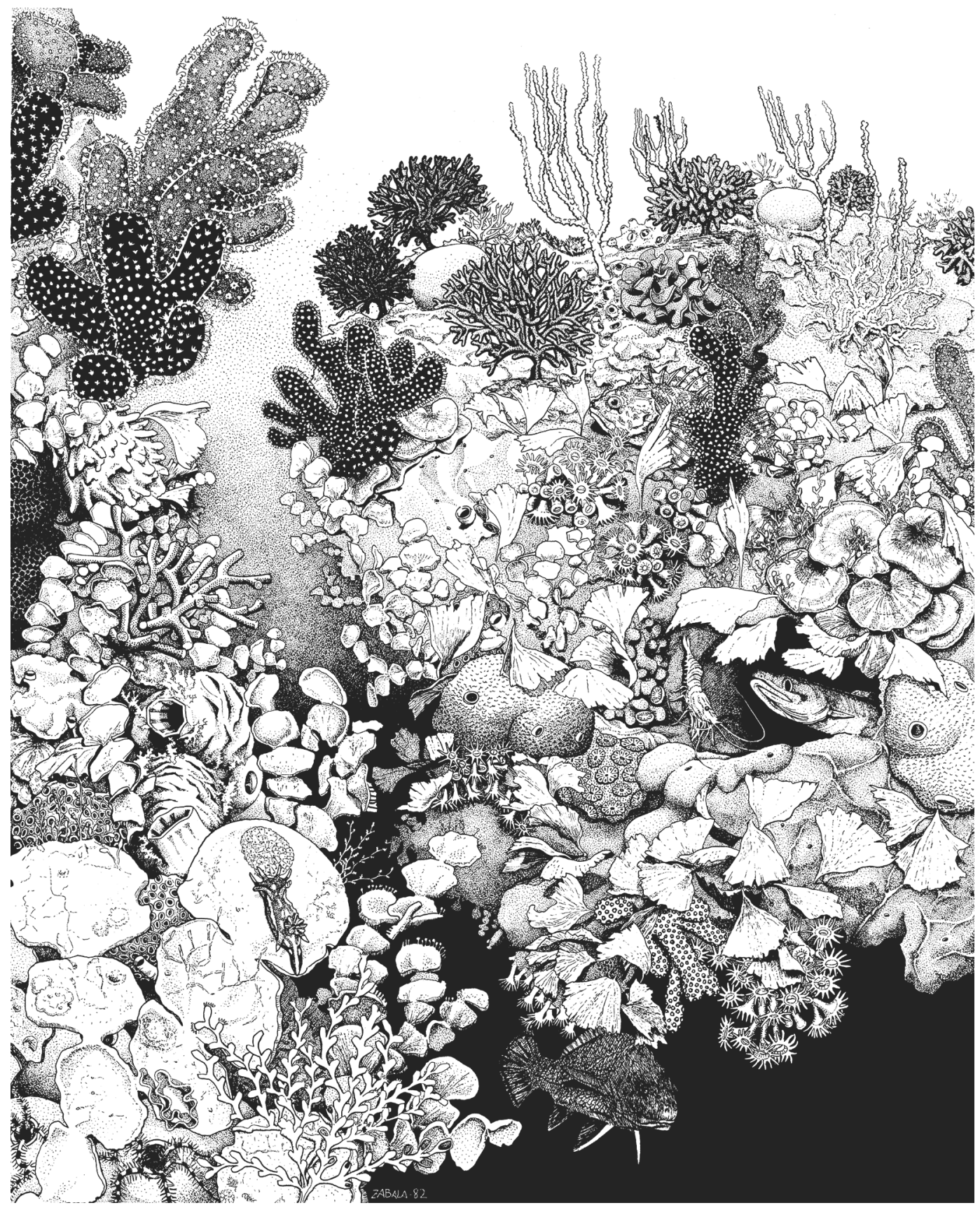

Figure 12 (A) Drawing of a coralligenous concretion dominated by algae in the Medes Islands (NE Spain).

2.3-0.3 $\mathrm{W} \mathrm{m}^{-2}$, which correspond, respectively, to 3 and $0.4 \%$ of the surface irradiance. Other quantified species lists are described in Marino et al. (1998).

In deeper waters or lower irradiances the density of Halimeda tuna decreases and other calcareous algae become dominant (Lithophyllum frondosum, Neogoniolithon mamillosum, Peyssonnelia rosa-marina) (Figure 14). Other common algae are members of the family Delesseriaceae 


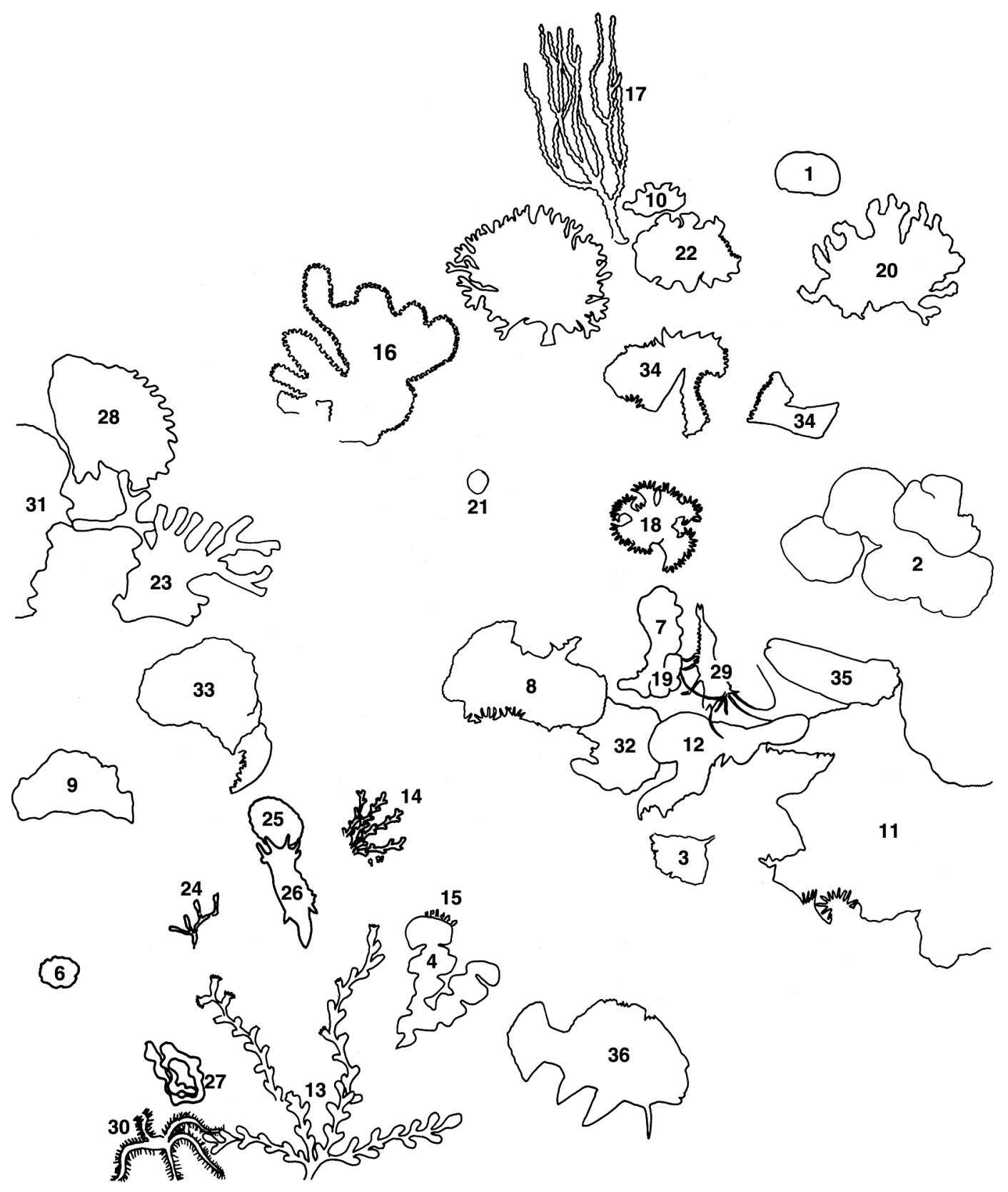

Figure 12 (continued) (B) Key to major species, on the left from top to bottom: Alcyonium acaule ${ }^{16}$, Crambe crambe on Spondylus gaederopus ${ }^{28}$, Cystodites dellechiajei ${ }^{31}$, Myriapora truncata ${ }^{23}$, Microcosmus sabatieri ${ }^{33}$, Hemimycale columella ${ }^{9}$, Sertularella ellisi ${ }^{13}$, Ophiothrix fragilii ${ }^{30}$, amid Halimeda tuna (a close up is shown at bottom left with, on it ${ }^{4}$, Titanoderma sp. ${ }^{6}$, Halecium halecinum ${ }^{14}$, Campanularia sp. ${ }^{15}$, Aetea truncata ${ }^{24}$, Watersipora subovoidea ${ }^{25}$ and Polycera quadrilineata ${ }^{26}$ with spawn mass ${ }^{27}$ below). At the centre and to the right, from top to bottom, and in addition to the abovementioned species: Eunicella singularis ${ }^{17}$, Codium bursa ${ }^{1}$, Codium vermilara ${ }^{5}$, Cliona viridis ${ }^{10}$, Pentapora fascialis ${ }^{22}$, Salmacina dysteri ${ }^{20}$, Scorpaena porcus ${ }^{34}$, Sabella sp. $^{21}$, Parazoanthus axinellae ${ }^{18}$, Peyssonnelia rubra ${ }^{2}$, Oscarella lobularis ${ }^{7}$, Ircinia variabilis ${ }^{8}$, Caryophyllia sp. ${ }^{19}$, Palaemon serratus ${ }^{29}$, Conger conger ${ }^{35}$, Botryllus schlosseri ${ }^{32}$, Agelas oroides $^{12}$, Crambe crambe ${ }^{11}$ and Sciaena umbra ${ }^{36}$, all amid Flabellia petiolata ${ }^{3}$. (Drawing by M. Zabala in Els Sistemes Naturals de les Illes Medes, Ros et al., 1984. With permission from M. Zabala and J. Ros.) 


\section{MEDITERRANEAN CORALLIGENOUS ASSEMBLAGES}
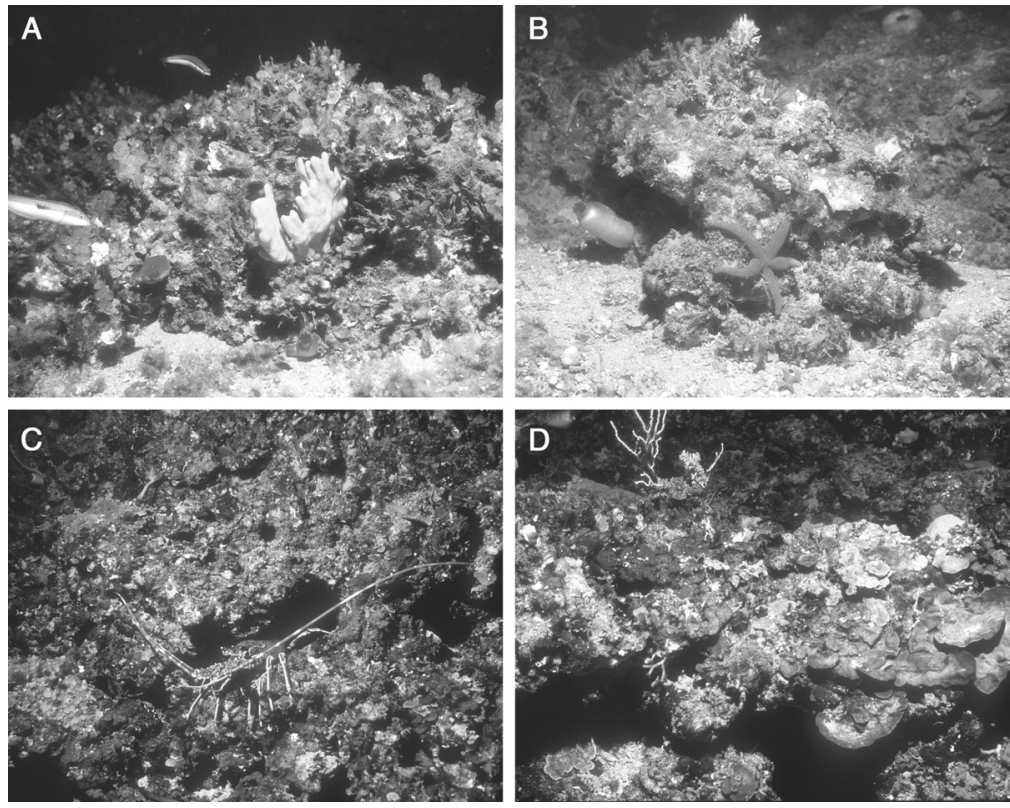

Figure 13 (See also Colour Figure 13 in the insert.) Different assemblages of algal-dominated coralligenous banks and rims; (A) with Halimeda tuna and Mesophyllum alternans (Tossa de Mar, NE Spain, $28 \mathrm{~m}$ depth); (B) with Lithophyllum frondosum (Tossa de Mar, NE Spain, $40 \mathrm{~m}$ depth); (C) with Peyssonnelia rosa-marina, Mesophyllum alternans, Palmophyllum crassum and Peyssonnelia squamaria (Scandola, Corsica, $50 \mathrm{~m}$ depth); (D) detail of C. (Photos by the author.)

and other laminar red algae (Kallymenia, Fauchea, Sebdenia, Rhodophyllis, Predaea), as well as the encrusting green alga Palmophyllum crassum. These assemblages correspond to the Rodriguezelletum strafforellii of Augier \& Boudouresque (1975), which may be identical to the algal assemblage described by Feldmann (1937) for coralligenous concretions from the Mediterranean Pyrenees (Figures 13B,C,D). Quantified species lists can be found in Boudouresque (1973), Augier \& Boudouresque (1975), Ballesteros (1992) and Marino et al. (1998). Algal biomass averages 1600 $\mathrm{g} \mathrm{m}^{-2}$ and percent cover $122 \%$, mostly corresponding to encrusting algae and, around $90 \%$, corresponding to corallines; the number of species is low (38 species in $1600 \mathrm{~cm}^{2}$ or lower) (Ballesteros 1992).

Animal assemblages of these two plant associations can differ greatly from one to the other, as well as between sites and geographical areas. The abundance of suspension feeders mainly depends on average current intensity and availability of food (plankton, POC, DOC). In the richest zones (e.g., Gulf of Lions, Marseilles area) gorgonians can dominate the community (Figure 15A,B), but in very oligotrophic waters (e.g., Balearic Islands, eastern Mediterranean), sponges, bryozoans and small hexacorals are the dominant suspension feeders (Figure 15C). The only available quantified biomass data of invertebrate assemblages are those of True (1970) gathered from the Marseilles area, and those results are summarized below.

True (1970) studied an assemblage dominated by Eunicella cavolinii. He reports a basal layer of encrusting algae accompanied by erect algae (total biomass of $163 \mathrm{~g} \mathrm{dw} \mathrm{m}^{-2}$ ). E. cavolinii is the most abundant species (up to $304 \mathrm{~g} \mathrm{dw} \mathrm{m}^{-2}$ ), followed by the bryozoans Pentapora fascialis (280.1 $\left.\mathrm{g} \mathrm{dw} \mathrm{m}^{-2}\right)$, Turbicellepora avicularis $\left(49.1 \mathrm{~g} \mathrm{dw} \mathrm{m}^{-2}\right)$, Celleporina caminata $\left(22.3 \mathrm{~g} \mathrm{dw} \mathrm{m}^{-2}\right)$ and Myriapora truncata $\left(19.9 \mathrm{~g} \mathrm{dw} \mathrm{m}^{-2}\right)$. Other less abundant species include unidentified Serpulidae, anthozoans Parerythropodium coralloides, Alcyonium acaule, Leptopsammia pruvoti and 


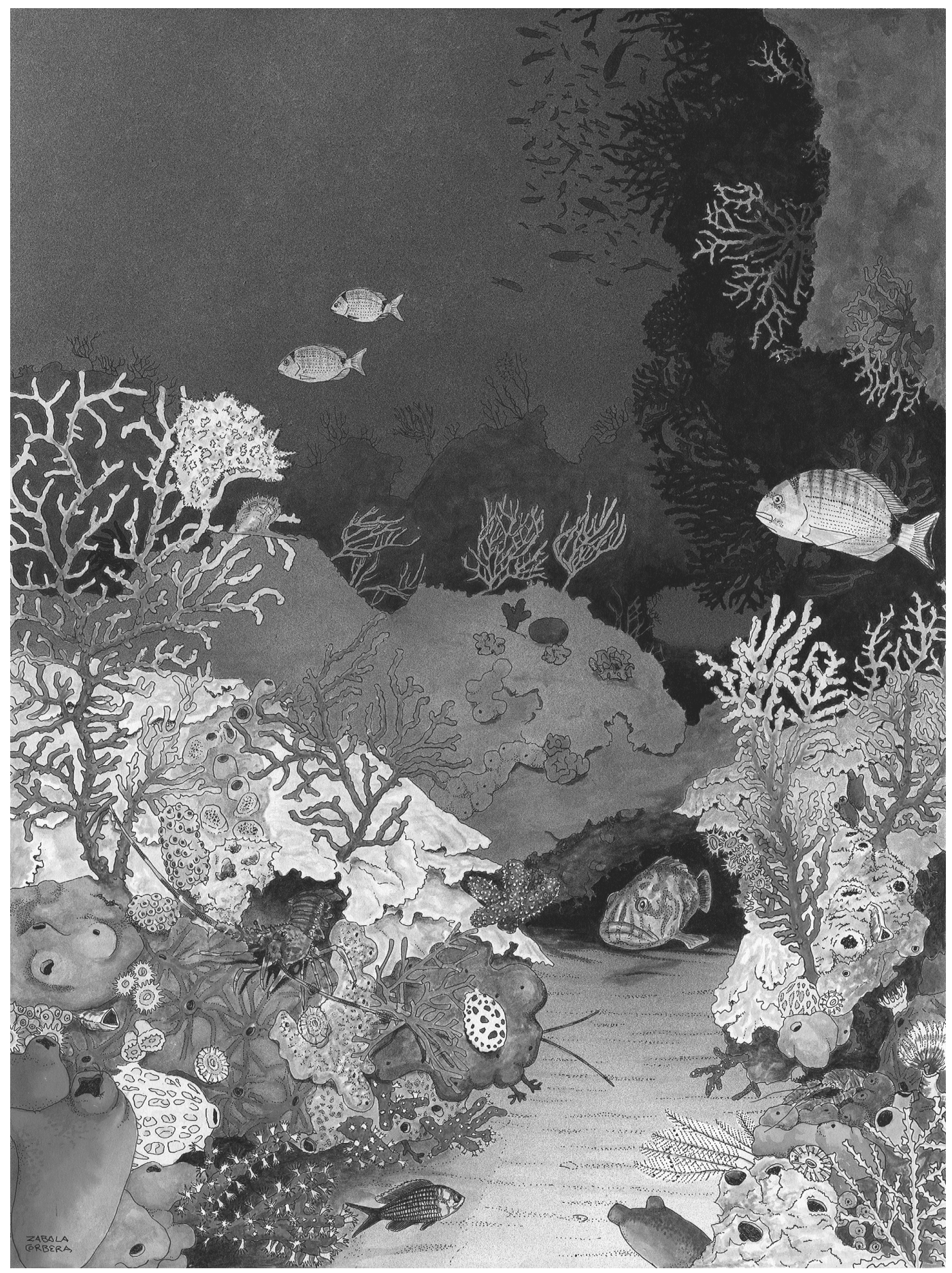

Figure 14 (See also Colour Figure 14 in the insert.) (A) Drawing of a deep-water, animal-dominated, coralligenous assemblage in the Medes Islands (NE Spain). 

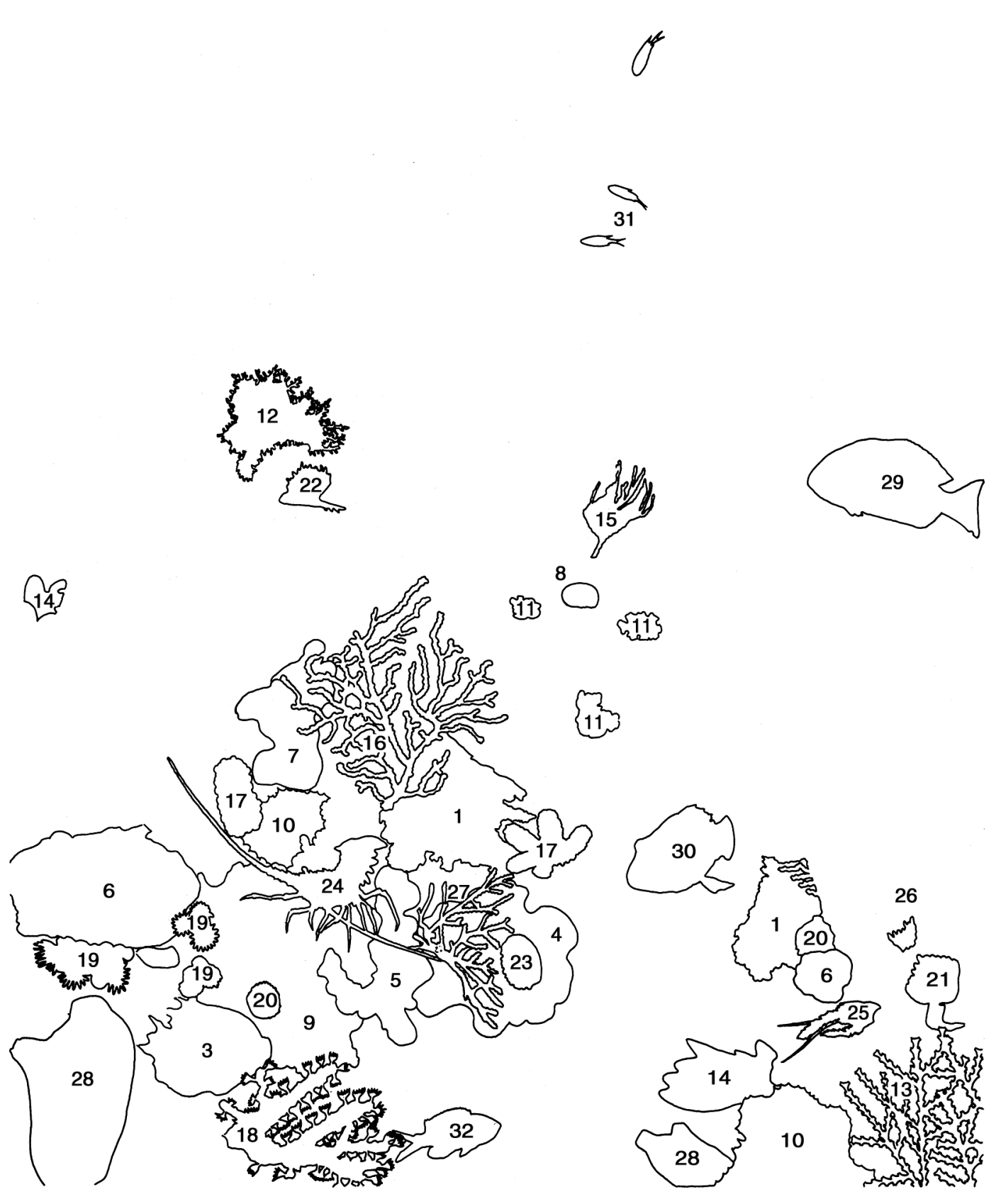

Figure 14 (continued) (See also Colour Figure 14 in the insert.) (B) Key to major species, left from top to bottom: Paramuricea clavata $^{6}$, (and on it Halecium halecinum ${ }^{12}$, Pteria hirundo ${ }^{22}$ ), Aglaophenia septifera ${ }^{14}$, Cliona viridis $^{7}$, Alcyonium acaule ${ }^{17}$, Acanthella acuta ${ }^{11}$, Lithophyllum frondosum ${ }^{1}$, Agelas oroides ${ }^{6}$, Palinurus elephas $^{24}$, Parazoanthus axinellae ${ }^{19}$, Spirastrella cunctatrix $^{9}$, Chondrosia reniformis ${ }^{5}$, Petrosia ficiformis ${ }^{4}$ (and on it Smittina cervicornis ${ }^{27}$ and Discodoris atromaculata ${ }^{23}$ ), Serpula vermicularis ${ }^{21}$, Caryophyllia inornata ${ }^{20}$, Halocynthia papillosa ${ }^{28}$, Clathrina coriacea ${ }^{3}$, Corallium rubrum ${ }^{18}$ and Chromis chromis. ${ }^{32}$ Right, from top to bottom (excluding the above-mentioned species): Anthias anthias ${ }^{31}$, Eunicella singularis ${ }^{15}$, Diplodus sargus ${ }^{29}$, Codium bursa ${ }^{8}$, Epinephelus marginatus ${ }^{30}$, Phyllangia mouchezii ${ }^{26}$, Galathea strigosa ${ }^{25}$, Synthecium evansi ${ }^{13}$, Dysidea avara ${ }^{10}$. (Drawing by M. Zabala \& J. Corbera.) 


\section{ENRIC BALLESTEROS}
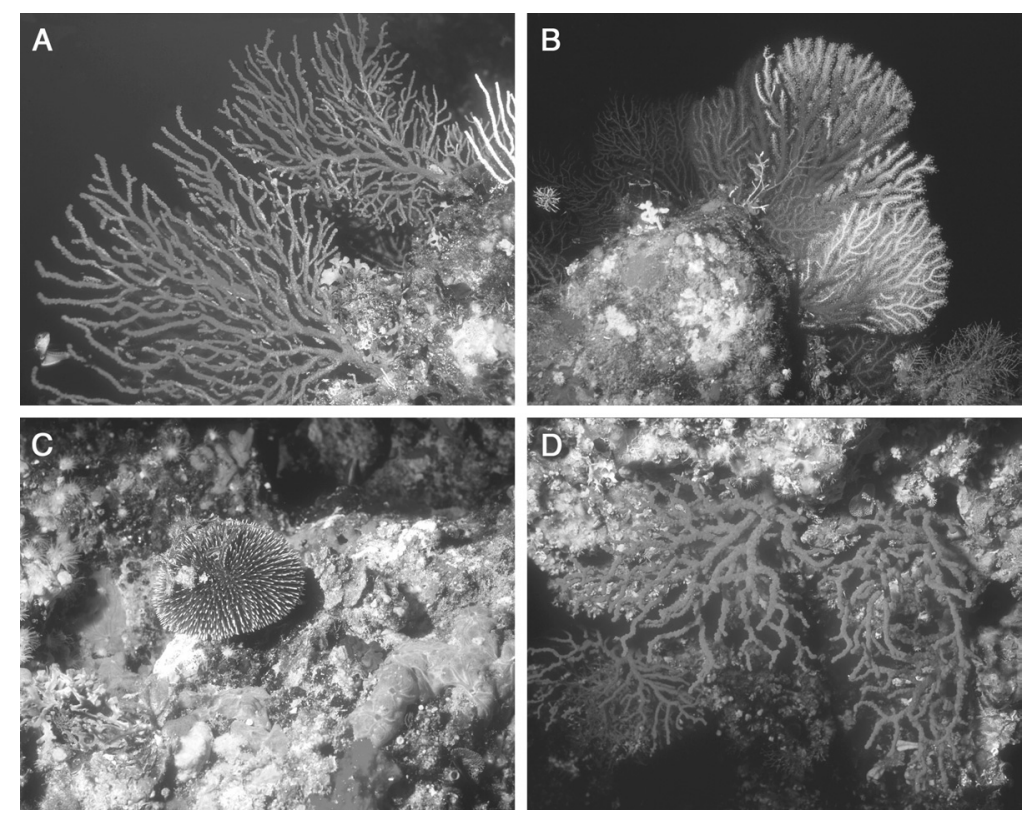

Figure 15 (See also Colour Figure 15 in the insert.) Different assemblages of animal-dominated coralligenous banks and rims; (A) with gorgonians Paramuricea clavata and Eunicella cavolinii but also green algae Halimeda tuna and Flabellia petiolata (Gargalo, Corsica, $45 \mathrm{~m}$ depth); (B) with Paramuricea clavata and encrusting sponges in deep waters (Cabrera, Balearic Islands, $65 \mathrm{~m}$ depth); (C) with sponges, bryozoans and anthozoans (Cabrera, Balearic Islands, $50 \mathrm{~m}$ depth); (D) overhangs with Corallium rubrum (Palazzu, Corsica, $35 \mathrm{~m}$ depth). (Photos by the author.)

Caryophyllia smithii, tunicates Microcosmus polymorphus and Halocynthia papillosa, foraminiferan Miniacina miniacea, sponges Chondrosia reniformis and Axinella damicornis and other bryozoans (Adeonella calveti, Beania hirtissima, Sertella spp., Schizomavella spp. and Cellaria salicornioides). The number of collected invertebrate species amounted to 146 in $7500 \mathrm{~cm}^{2}$, with a total weight of invertebrates close to $1563 \mathrm{~g} \mathrm{dw} \mathrm{m}^{-2}$. The main biomass corresponded to the phylum Bryozoa, closely followed by Cnidaria, and, with much lower values, Annelida, Porifera, Chordata (tunicates) and Mollusca.

Another assemblage studied by True (1970) is that dominated by Paramuricea clavata. Populations of $P$. clavata are abundant in steep rocky walls, but they also grow in horizontal to subhorizontal surfaces if light levels are very low. The basal layer of the community can be mainly occupied by algae (usually attributable to Rodriguezelletum strafforellii association) or by other suspension feeders (sponges and bryozoans). The lists of True (1970) do not report any algae. Paramuricea clavata has a total biomass of $746 \mathrm{~g} \mathrm{dw} \mathrm{m}^{-2}$, followed by the cnidarians Caryophyllia smithii $\left(326.3 \mathrm{~g} \mathrm{dw} \mathrm{m}^{-2}\right)$ and Hoplangia durotrix $\left(188.1 \mathrm{~g} \mathrm{dw} \mathrm{m}^{-2}\right)$, the bryozoan Celleporina caminata $\left(119.6 \mathrm{~g} \mathrm{dw} \mathrm{m}^{-2}\right)$, the anthozoan Leptopsammia pruvoti $\left(54.9 \mathrm{~g} \mathrm{dw} \mathrm{m}^{-2}\right)$, the bryozoans Adeonella calveti $\left(32.8 \mathrm{~g} \mathrm{dw} \mathrm{m}^{-2}\right)$ and Turbicellepora avicularis $\left(31.4 \mathrm{~g} \mathrm{dw} \mathrm{m}^{-2}\right)$, and red coral (Corallium rubrum, $16.9 \mathrm{~g} \mathrm{dw} \mathrm{m}^{-2}$ ). Other less abundant species include unidentified Serpulidae, sponges Ircinia variabilis (fasciculata in True, 1970), Spongia officinalis, Sarcotragus spinosula, Cacospongia scalaris, Petrosia ficiformis, Aplysina cavernicola, Erylus euastrum and Agelas oroides, the bryozoan Sertella septentrionalis, the alcyonarian Parazoanthus axinellae, molluscs Pteria hirundo, Serpulorbis arenarius, Lithophaga lithophaga and Anomia ephippium, and tunicates Microcosmus polymorphus and Polycarpa pomaria. The number of collected invertebrate species 


\section{MEDITERRANEAN CORALLIGENOUS ASSEMBLAGES}

amounts to 111 in $7500 \mathrm{~cm}^{2}$, with a total weight of $3175 \mathrm{~g} \mathrm{dw} \mathrm{m}^{-2}$. The main biomass corresponds to the phylum Cnidaria, followed by Annelida, Bryozoa, Porifera, Mollusca and Chordata.

Gili \& Ballesteros (1991) described the species composition and abundance of the cnidarian populations in coralligenous concretions around the Medes Islands that are dominated by the gorgonian Paramuricea clavata. Total cnidarian biomass amounted to $430 \mathrm{~g} \mathrm{dw} \mathrm{m}^{-2}$, with 13 species of hydrozoans and 9 species of anthozoans found in an area of $5202 \mathrm{~cm}^{2}$. Species contributing the most to the total biomass of the taxocoenosis were the anthozoans Paramuricea clavata, Leptopsammia pruvoti, Parazoanthus axinellae, Caryophyllia inornata, C. smithii, Alcyonium acaule and Parerythropodium coralloides, the hydrozoans Sertularella gaudichaudii and Halecium tenellum also being abundant.

Overhangs and big cavities of coralligenous assemblages have a different species composition to that found in open waters (Figure 15D). Algae are usually completely absent because light is very reduced. However, some thalli of encrusting corallines, Peyssonnelia spp. and Palmophyllum crassum, can occasionally be found. There are no quantified species lists for this kind of habitat reported in the literature except for those of True (1970), which, in fact, do not come from a coralligenous buildup but from a semidark zone dominated by red coral in a cave (Grotte de l'Île Plane). This assemblage is worth describing as it is very similar to those that develop in the overhangs of coralligenous constructions in the northwestern Mediterranean, or in coralligenous communities situated in very deep waters.

The assemblage of red coral described by True (1970) is dominated by the cnidarians Corallium rubrum (2002 $\left.\mathrm{g} \mathrm{dw} \mathrm{m}^{-2}\right)$, Caryophyllia smithii $\left(303 \mathrm{~g} \mathrm{dw} \mathrm{m}^{-2}\right)$, Hoplangia durotrix $\left(54.1 \mathrm{~g} \mathrm{dw} \mathrm{m}^{-2}\right)$ and Leptopsammia pruvoti $\left(52.4 \mathrm{~g} \mathrm{dw} \mathrm{m}^{-2}\right)$, the sponges Petrosia ficiformis $\left(241.5 \mathrm{~g} \mathrm{dw} \mathrm{m}^{-2}\right)$ and Aplysina cavernicola $\left(27.9 \mathrm{~g} \mathrm{dw} \mathrm{m}^{-2}\right)$, the bryozoan Celleporina caminata $\left(100.5 \mathrm{~g} \mathrm{dw} \mathrm{m}^{-2}\right)$, and unidentified Serpulidae $\left(232.4 \mathrm{~g} \mathrm{dw} \mathrm{m}^{-2}\right)$. Other abundant species are the sponges Ircinia variabilis, Spongia officinalis, Aaptos aaptos and Ircinia oros, the molluscs Chama gryphoides and Anomia ephippium, and several unidentified bryozoans. The total number of identified invertebrate species is 63 in $7500 \mathrm{~cm}^{2}$, with a total biomass of $3817 \mathrm{~g} \mathrm{dw} \mathrm{m}^{-2}$. The dominant phylum is largely the Cnidaria, although Porifera, Annelida and Bryozoa are also abundant.

It should be remembered that most of the invertebrate data presented in this chapter, if representative at all, reflect the biomass and species composition of several assemblages of coralligenous buildups from the Gulf of Lions, which are different to those reported from other sites of the western Mediterranean (e.g., Balearic Islands; Ballesteros et al. 1993) or the eastern Mediterranean (Pérès \& Picard 1958, Laborel 1960). Therefore, these data cannot be extrapolated to the whole Mediterranean.

\section{Biodiversity}

Coralligenous communities constitute the second most important 'hot spot' of species diversity in the Mediterranean, after the Posidonia oceanica meadows (Boudouresque 2004a). However, there appear to be no previous estimates of the number of species that thrive in these coralligenous assemblages. Furthermore, due to their rich fauna (Laubier 1966), complex structure (Pérès \& Picard 1964, Ros et al. 1985), and the paucity of studies dealing with coralligenous biodiversity, they probably harbour more species than any other Mediterranean community. In fact, coralligenous assemblages are one of the preferred diving spots for tourists due to the great diversity of organisms (Harmelin 1993). Divers are astonished by the high number of species belonging to taxonomic groups as diverse as sponges, gorgonians, molluscs, bryozoans, tunicates, crustaceans or fishes. Moreover, there are innumerable organisms living in these coralligenous communities that cannot be observed by diving, nor without a careful sorting of samples. For example, in a sample of $370 \mathrm{~g}$ dw of Mesophyllum from a small coralligenous concretion in the south of Spain, García-Raso 


\section{ENRIC BALLESTEROS}

(1988) found 903 specimens of crustaceans, molluscs and polychaetes; other organisms from other groups (pycnogonids, nematodes, echinoderms, sipunculids, sponges, tunicates, small fishes, such as Gobiidae and Blenniidae, as well as hydrozoans and bryozoans) were also abundant, although not quantified.

Laubier (1966) was the first author to emphasize the great biodiversity of coralligenous communities and listed 544 invertebrates from coralligenous assemblages in the region of Banyuls. Later, in an exhaustive survey of coralligenous communities around Marseilles, Hong (1980) listed a total of 682 species, while several authors (in Ros et al. 1984) report 497 species of invertebrates in the coralligenous assemblages of the Medes Islands. Estimates of the species richness found in coralligenous communities give a very conservative number of 1241 invertebrates (Table 2). Boudouresque (1973) has estimated that at least 315 species of macroalgae can thrive in Mediterranean sciaphilic communities (the coralligenous type being the most widespread). Finally, there are no estimates of the number of fishes that can be found in coralligenous communities, due to the high mobility of most species of this group, but estimates based on available literature regarding the biology of Mediterranean fishes (e.g., Whitehead et al. 1984-1986, Corbera et al. 1996, Mayol et al. 2000) range between 110 and 125 species.

It is very difficult to mention all the species found to date in coralligenous communities, as the existing taxonomic literature is huge and contains many synonyms; this makes it impossible for a nonspecialist in most of the groups to come up with an accurate number of reported species. Nevertheless, an attempt is made at a first, and very conservative, estimate of the total number of species, which amounts to some 1,666 (Table 2). A first step toward increased knowledge of the biodiversity present in coralligenous communities would be to obtain a more accurate estimate of which species have been found and their number.

The next section describes the main findings reported for each taxonomic group.

\section{Taxonomic groups}

Algae

At least 315 species of macroalgae thrive in deep-water Mediterranean sciaphilic communities (Boudouresque 1973), and most of them are found in coralligenous concretions. The algal assemblages found here show high biodiversity, with an average of 40 algal species in $600 \mathrm{~cm}^{2}$.

Boudouresque (1973) defined the ecological group of algae characteristic of coralligenous concretions (CC or Rodriguezellikon), which (Boudouresque, 1985) comprises 28 species (e.g., Rodriguezella spp., Aeodes marginata, Fauchea repens, Chondrymenia lobata, Gulsonia nodulosa, Polysiphonia elongata, Neogoniolithon mamillosum). However, coralligenous communities are never dominated by this group of species, but rather by other species with a more depth-related widespread distribution, examples being the encrusting corallines Mesophyllum alternans, Lithophyllum frondosum, and L. cabiochae, the green algae Palmophyllum crassum, Flabellia petiolata, Halimeda tuna and Valonia macrophysa, some brown algae such as Dictyota dichotoma, Dictyopteris polypodioides, Spatoglossum solierii, Zonaria tournefortii, Halopteris filicina, Phyllariopsis brevipes, Zanardinia prototypus and Laminaria rodriguezii, and a large number of red algae (several species of Peyssonnelia, Kallymenia, Halymenia, Sebdenia, Predaea, Eupogodon, Myriogramme, Neurocaulon foliosum, Acrodiscus vidovichii, Osmundaria volubilis, Phyllophora crispa, Rhodymenia ardissonei, Acrosorium venulosum, Rhodophyllis divaricata, Hypoglossum hypoglossoides, Polysiphonia banyulensis, Plocamium cartilagineum, Sphaerococcus coronopifolius, Erythroglossum sandrianum, and Aglaothamnion tripinnatum) (Boudouresque 1973, 1985, Ballesteros 1992, 1993).

The algal component of coralligenous communities largely consists of Mediterranean endemics, which quantitatively represent between 33 and $48 \%$ of the total flora (Boudouresque 1985). 


\section{MEDITERRANEAN CORALLIGENOUS ASSEMBLAGES}

Table 2 Approximate number of species reported from coralligenous communities

\begin{tabular}{|c|c|c|}
\hline Group & Totals & References \\
\hline Algae & 315 & Boudouresque 1973 \\
\hline Protozoans & 61 & Laubier 1966, Hong 1980 \\
\hline Sponges & 142 & $\begin{array}{l}\text { Laubier 1966, Hong 1980, Ros et al. 1984, Ballesteros et al. 1993, } \\
\text { Ballesteros \& Tomas 1999, Rosell \& Uriz } 2002\end{array}$ \\
\hline Hydrozoans & 55 & Laubier 1966, Ros et al. 1984, Ballesteros et al. 1993, Rosell \& Uriz 2002 \\
\hline Anthozoans & 43 & $\begin{array}{l}\text { Laubier 1966, Ros et al. 1984, Ballesteros et al. 1993, Ballesteros \& Tomas } \\
\text { 1999, Ballesteros, unpublished data }\end{array}$ \\
\hline Scyphozoans & 1 & Laubier 1966, Hong 1980 \\
\hline Turbellarians & 3 & Laubier 1966, Hong 1980 \\
\hline Nemerteans & 12 & Laubier 1966 \\
\hline Polychaetes & 191 & Martin 1987 \\
\hline Sipunculids & 3 & Laubier 1966, Hong 1980 \\
\hline Echiurids & 2 & Laubier 1966 \\
\hline Chitons & 7 & Hong 1980 \\
\hline Prosobranchs & 61 & Hong 1980 \\
\hline Opisthobranchs & 33 & Hong 1980 \\
\hline Bivalves & 41 & Hong 1980 \\
\hline Cephalopods & 3 & Ballesteros \& Tomas 1999 \\
\hline Mites & 6 & Laubier 1966 \\
\hline Pycnogonids & 15 & Hong 1980 \\
\hline Copepods & 54 & Laubier 1966 \\
\hline Ostracods & 10 & Laubier 1966 \\
\hline Cirripedes & 3 & Laubier 1966, Hong 1980 \\
\hline Phyllocarids & 1 & Hong 1980 \\
\hline Mysids & 7 & Hong 1980 \\
\hline Cumaceans & 3 & Laubier 1966, Hong 1980 \\
\hline Tanaidaceans & 2 & Laubier 1966, Hong 1980 \\
\hline Isopods & 14 & Laubier 1966, Hong 1980 \\
\hline Amphipods & 100 & Bellan-Santini 1998 \\
\hline Decapods & 56 & García-Raso 1988, 1989 \\
\hline Brachiopods & 8 & Logan 1979 \\
\hline Pterobranchs & 1 & Laubier 1966 \\
\hline Bryozoans & 171 & Zabala 1986 \\
\hline Crinoids & 2 & Tortonese 1965 \\
\hline Ophiuroids & 17 & Laubier 1966, Tortonese 1965 \\
\hline Echinoids & 14 & $\begin{array}{l}\text { Tortonese 1965, Laubier 1966, Hong 1980, Ros et al. 1984, Munar 1993, } \\
\text { Ballesteros et al. 1993, Ballesteros \& Tomas } 1999\end{array}$ \\
\hline Asteroids & 8 & Tortonese 1965, Laubier 1966, Munar 1993 \\
\hline Holothurioids & 9 & $\begin{array}{l}\text { Tortonese 1965, Laubier 1966, Hong 1980, Ros et al. 1984, Munar 1993, } \\
\text { Ballesteros et al. 1993, Ballesteros \& Tomas } 1999\end{array}$ \\
\hline Tunicates & 82 & Ramos 1991 \\
\hline Fishes & 110 & Whitehead et al. 1984-1986, Ballesteros, unpublished data \\
\hline
\end{tabular}

Coralligenous communities are rich in algal species, although this richness is lower than that found in photophilic or moderately sciaphilic communities (Ballesteros 1992). Ballesteros (1991b) reports 90 species of macroalgae from the coralligenous assemblages of Tossa de Mar, where Mesophyllum alternans and Halimeda tuna dominate, but only 38 in the coralligenous communities from a deep water site (Ballesteros 1992). Piazzi et al. (2004) found small differences between algal assemblages of coralligenous habitats along the coast of Tuscany (Italy). However, algal 


\section{ENRIC BALLESTEROS}

populations in coralligenous habitats differ greatly on geographical scales across the whole Mediterranean (Boudouresque 1973) and this is the main reason why, even if the species diversity at one site is rather constant, the overall algal richness of coralligenous habitats - on a Mediterraneanwide scale and covering all depths where they are present — can be huge.

\section{Protozoa}

Fifty-four species of Foraminifera are listed by Hong (1980) in the checklist of species from the coralligenous communities of Marseilles, although none of these species seems to be characteristic of coralligenous habitats. Miniacina miniacea is the most abundant species, and other common species include Massilina secans, Planorbulina mediterranensis, Elphidium crispum and Triloculina rotunda. Laubier (1966) reports six species of Folliculinidae living as epibionts of bryozoans.

\section{Porifera}

Coralligenous communities are very rich in sponges, which grow mainly in the more sciaphilic environments but also in more exposed areas. There are also some species (Clionidae) that are active bioeroders and which excavate the coralline framework. The number of species reported from different well-studied areas is 26 species from Banyuls (Laubier 1966), 78 species from Marseilles (Hong 1980), 48 species from the Medes Islands (Bibiloni et al. 1984), 74 species from Cabrera (Ballesteros et al. 1993), and 24 species from Tossa (Ballesteros \& Tomas 1999). The list of sponges reported in all these studies (along with those of True 1970 and Rosell \& Uriz 2002) amounts to 142 different species. According to Hong (1980) the following species are characteristic of coralligenous biocoenoses: Axinella damicornis, Acanthella acuta, Hymedesmia pansa, Agelas oroides, Dictyonella pelligera, Haliclona mediterranea, Spongionella pulchella and Faciospongia cavernosa. Other abundant sponges (Laubier 1966, True 1970, Hong 1980, Bibiloni et al. 1984, Ballesteros et al. 1993, Ballesteros \& Tomas 1999) are: Cliona viridis, Clathrina clathrus, Oscarella lobularis, Chondrosia reniformis, Phorbas tenacior, Geodia cydonium, Aaptos aaptos, Pleraplysilla spinifera, Dysidea avara, Terpios fugax, Spongia virgultosa, S. agaricina, S. officinalis, Ircinia variabilis, I. oros, Axinella verrucosa, A. polypoides, Diplastrella bistellata, Petrosia ficiformis, Hexadella racovitzai, Cacospongia scalaris, Dictyonella obtusa, Erylus euastrum, Hippospongia communis, Reniera cratera, R. fulva, R. mucosa, Spirastrella cunctatrix, Spongosorites intricatus and Hemimycale columella.

The coralligenous communities from the eastern Mediterranean seem to be very rich in sponges (Pérès \& Picard 1958) because they are almost devoid of alcyonarians and gorgonians. The most abundant species have already been cited above. Those of the genus Axinella (A. polypoides, A. damicornis, A. verrucosa), Agelas oroides and Petrosia ficiformis (Pérès \& Picard 1958) are particularly common.

\section{Hydrozoa}

Laubier (1966) reports 16 hydrozoans from the coralligenous communities of Banyuls but none is listed by Hong (1980). Gili et al. (1984) report 44 species of hydrozoans from the coralligenous and precoralligenous communities of the Medes Islands. According to Laubier (1966) and Gili et al. (1984, 1989) some species of hydrozoans are common on deep-water rocky bottoms and coralligenous assemblages, namely Nemertesia antennina, Eudendrium rameum, Filellum serpens, Dynamena disticha, Clytia hemisphaerica, Hebella scandens, Sertularella polyzonias, S. gayi, S. ellisi, S. crassicaulis, Laomedea angulata and Cuspidella humilis.

The only detailed study of hydrozoans found on coralligenous assemblages is that of Llobet et al. (1991a), who report 35 species of hydroids living on the thalli of Halimeda tuna in the coralligenous concretions of Tossa de Mar (northwestern Mediterranean). Llobet et al. (1991a) 


\section{MEDITERRANEAN CORALLIGENOUS ASSEMBLAGES}

classify the most abundant hydrozoans into three categories on the basis of their horizontal zonation on the thalli. The hydroids common on the proximal articles (oldest) are relatively large and present throughout the year (Eudendrium racemosum, E. capillare, Halecium tenellum and Kirchenpaueria echinulata). Those common on the medial articles (Campalecium medusiferum, Halecium pusillum, Hydranthea margarica, Phialella quadrata, Campanularia everta and Filellum serpens) are smaller and often occur in dense monospecific patches. Finally, those common on the distal articles (Campanularia raridentata, Clytia hemisphaerica, Sertularia distans, Sertularella polyzonias and Aglaophenia pluma) are present for only short periods and are highly opportunistic. This zonation seems to reflect interspecific niche selection, enabling successful competition for space with other hydroids, algae and bryozoans.

\section{Anthozoa}

Studies by Laubier (1966), True (1970), Hong (1980) and Gili et al. (1984, 1989) report several species of anthozoans from coralligenous habitats (up to 33 in Gili et al. 1984). The commonest species are Parazoanthus axinellae, Leptopsammia pruvoti, Parerythropodium coralloides, Alcyonium acaule, Paramuricea clavata, Eunicella singularis, E. cavolinii, Rolandia rosea, Corallium rubrum, Telmatactis elongata, Maasella edwardsii, Monomyces pygmaea, Hoplangia durotrix, Caryophyllia inornata, C. smithii, Clavularia ochracea, Cornularia cornucopiae and Epizoanthus arenaceus. Madracis pharensis is especially abundant in the coralligenous outcrops of the eastern Mediterranean (Laborel 1960).

Scyphozoa

The only species reported (Hong, 1980) is Nausitoë punctata, living inside several massive sponges.

\section{Turbellaria}

Laubier (1966) reports three turbellarians from the coralligenous communities of Banyuls, all very rare.

\section{Nemertea}

Nemerteans live endolithically in concretions. According to Pruvot (1897) and Laubier (1966), who report up to 12 species in the coralligenous communities of Banyuls, they are rather common. Drepanophorus crassus, Tetrastemma coronatum, Micrura aurantiaca and M. fasciolata are the most abundant.

\section{Nematoda}

Nematodes are the most abundant microscopic metazoans in marine sediments and are present in the sediments retained in coralligenous assemblages, as well as in the endofauna of concretions and the epifauna of algae and sessile invertebrates. However, there are no studies dealing with this group of organisms in coralligenous assemblages.

\section{Polychaeta}

Polychaetes are extremely abundant in coralligenous communities. Martin (1987) reported a total of 9195 individuals present in 20 samples of $400 \mathrm{~cm}^{2}$ collected from coralligenous communities dominated by Mesophyllum alternans and Lithophyllum frondosum from the Catalan coast (northwestern Mediterranean). This means an average of 460 worms per sample and a density of more than one individual per $\mathrm{cm}^{2}$. He found 191 species, with a dominance of Syllidae (31\% of the total). The number of species per sample was very high, ranging between 32 and 71 for macrofauna 


\section{ENRIC BALLESTEROS}

$(>0.4 \mathrm{~mm})$ and between 27 and 55 for microfauna $(<0.04 \mathrm{~mm})$. Diversity of the samples was also very high, averaging 4.54 bits ind $^{-1}$ for macrofauna and 4.34 bits ind $^{-1}$ for microfauna (ShannonWeaver index). According to Martin (1987), coralligenous assemblages are a very suitable habitat for polychaetes because the high structural complexity of the concretions allows the coexistence of several species in a reduced space.

The first checklist of polychaetes collected from coralligenous communities and studied by a specialist is that of Bellan (1964), who reported 70 species.

Laubier (1966) reported 130 species in the polychaete assemblages of two coralligenous stations in the Banyuls region; Lepidasthenia elegans, Kefersteinia cirrata, Xenosyllis scabra and Typosyllis variegata were the most abundant. According to his observations, and those of Bellan (1964), the polychaetes inhabiting coralligenous concretions are mainly ubiquitous species, although he distinguished two main groups: microfauna and macrofauna. Microfauna comprise three ecological groups: psammophilic species (e.g., Xenosyllis scabra, Eurysillis tuberculata, Trypanosyllis coeliaca), limic species (e.g., Scalibregmatidae, Sclerocheilus minutus), and the strictly endogean species, which are the most 'characteristic' of coralligenous habitats (e.g., Pholoe minuta, Chrysopetalum caecum, Eulalia tripunctata, Sige microcephala, Opisthodonta morena, Syllides longocirrata). Among the macrofauna he distinguished four ecological groups: polychaetes living inside sponges (e.g., Lepidasthenia elegans, Eunice siciliensis, Amphitrite variabilis); species living in small crevices and holes, like most Serpulidae and Terebellidae, as well as Eunice torquata; big vagile polychaetes living over or inside coralligenous holes (e.g., Lepidonotus clava, Harmothoe aerolata, Pontogenia chrysocoma, Trypanosyllis zebra) and, finally, excavating species of the genus Dipolydora and Dodecaceria concharum.

Hong (1980) reported a total of 109 species of polychaetes inhabiting the coralligenous communities of Marseilles, and distinguished some characteristic species such as Haplosyllis spongicola, Trypanosyllis coeliaca, Platynereis coccinea, Eunice torquata, Lumbrinereis coccinea and Potamilla reniformis. According to Martin (1987), who studied polychaete fauna in the coralligenous communities from the Catalan coast, the most dominant and constant species are Filograna implexa, Spirobranchus polytrema, Polydora caeca, Pomatoceros triqueter, Nereis pelagica, Syllis truncata, S. gerlachi, Haplosyllis spongicola, Serpula concharum, Anaitides muscosa and Dodecaceria concharum. However, the most conspicuous species growing in coralligenous communities are not usually the most abundant, but rather the large and very apparent species of serpulids (True 1970) notably Salmacina dysteri, Serpula vermicularis, S. concharum, Sabella pavonina, S. spallanzani, Myxicola aesthetica and Protula spp. (Ballesteros \& Tomas 1999).

\section{Sipunculida}

Always endolithic, the most abundant species of sipunculid is Phascolosoma granulatum, which, along with Aspidosiphon mülleri, is also a very active bioeroder (Sartoretto 1996). Laubier (1966) reports a third species in the coralligenous community of Banyuls: Golfingia minuta.

\section{Echiura}

Bonellia viridis, very common in coralligenous communities, is an important detritus feeder. Laubier (1966) reports another, extremely rare species from the coralligenous community of Banyuls (Thalassema sp.).

\section{Mollusca}

Molluscs are extremely abundant in coralligenous communities. Martin et al. (1990) reported a total of 897 individuals in 20 samples of $400 \mathrm{~cm}^{2}$, equivalent to an average of 45 species per sample 


\section{MEDITERRANEAN CORALLIGENOUS ASSEMBLAGES}

and more than one mollusc per $10 \mathrm{~cm}^{2}$. They report a very high number of species given the reduced area they sampled: 131. The number of species per sample ranged between 5 and 33. Average diversity for all the samples was 3 bits ind $^{-1}$ (Shannon-Weaver index). Salas \& Hergueta (1986) also reported a very high diversity, with an average of 22.7 species per sample.

The number of species reported in studies devoted to the coralligenous communities of a small geographic area are always high: 69 species in Banyuls (Laubier 1966), 142 species in Marseilles (Hong 1980) and 108 species in the Medes Islands (Huelin \& Ros 1984). According to these authors, and to Martin et al. (1990), the most common and constant species are the chiton Callochiton achatinus; the prosobranchs Acmaea virginea, Calliostoma zizyphinum, Alvania lineata, A. cancellata, Setia semistriata, S. tenera, Chauvetia minima, C. mamillata, Hinia incrassata, Fusinus pulchellus, F. rostratus, Raphitoma linearis, Clanculus corallinus, Rissoina bruguierei, Triphora perversa, Muricopsis cristatus and Bittium reticulatum; the opisthobranchs Odostomia rissoides, Diaphorodis papillata, Limacia clavigera, Cadlina laevis, Hypselodoris fontandraui, Chromodoris luteorosea, C. purpurea, Dendrodoris grandiflora, Duvaucelia striata, Discodoris atromaculata, Glossodoris gracilis, G. tricolor, Polycera quadrilineata, Flabellina affinis and Dondice banyulensis and the bivalves Arca barbata, Striarca lactea, Musculus costulatus, Kellia suborbicularis, Lithophaga lithophaga, Coralliophaga lithophagella, Anomia ephippium, Pteria hirundo, Chlamys multistriata, Chama gryphoides, Lima lima and Hiatella arctica.

Cephalopods are also present in coralligenous communities, although they are usually not reported in lists. Both Octopus vulgaris and Sepia officinalis are regularly present. Loligo vulgaris eggs are frequently seen in late winter and early spring in some coralligenous platforms.

Acari

Mites are always rare in coralligenous communities. Laubier (1966) reports six species from Banyuls.

Pycnogonida

Up to 15 species of pycnogonids occur in the coralligenous communities of Marseilles (Hong 1980). Achelia echinata, Rynchothorax mediterraneus, Tanystylum conirostre and Callipallene spectrum seem to be the most common, although they are always rare. Only one species is reported by Laubier (1966) from Banyuls, and two species by Munilla \& De Haro (1984) from the Medes Islands.

\section{Copepoda}

The fauna of copepods has been carefully studied by Laubier (1966) in one station from the coralligenous communities of Banyuls. He reports up to 54 species. Ectinostoma dentatum, Harpacticus littoralis, Tisbe furcata, Thalestris rufoviolescens, Phyllothalestris mysis, Dactylopodia tisboides, Diosaccus tenuicornis, Amphiascus minutus, A. cinctus and Laophonte cornuta are extremely abundant. There are several copepods which live as parasites of different invertebrates: polychaetes, sponges, echinoderms, molluscs, cnidarians and tunicates (Laubier 1966 and references therein).

\section{Ostracoda}

Although several species of ostracods are present in coralligenous communities (Laubier 1966, Hong 1980), no study has been devoted to this group. Laubier (1966) reports more than 10 unidentified species in the 'endogean' microfauna. 


\section{ENRIC BALLESTEROS}

\section{Cirripedia}

The barnacles Balanus perforatus and Verruca strömia, in coralligenous walls and crevices, and Acasta spongites, an endobiont of several sponges (e.g., Dysidea, Ircinia), have been identified in coralligenous communities (Laubier 1966, Hong 1980, Carbonell 1984).

Phyllocarida

Only one species has been recorded in the coralligenous communities of Marseilles (Hong 1980).

Mysidacea

Hong (1980) reports seven mysids from the coralligenous communities of Banyuls.

\section{Cumacea}

Three cumaceans are reported from coralligenous communities and are always rare (Laubier 1966, Hong 1980).

\section{Tanaidacea}

Tanais cavolini and Leptochelia savignyi are rather common among the 'endogean' microfauna of coralligenous frameworks (Laubier 1966, Hong 1980).

\section{Amphipoda}

A noteworthy number of amphipods have been sampled in coralligenous communities. Although Laubier (1966) only reports 12 species from the coralligenous communities of Banyuls, a list of 49 species is given by Hong (1980) in Marseilles, and 40 species are reported by Jimeno \& Turon (1995) in an extensive survey of the concretions by Mesophyllum alternans along the coast of Catalonia (northwestern Mediterranean).

Coralligenous assemblages harbour a certain number of amphipods from photophilic algal communities, together with rheophobic and sciaphilic species, which are linked to the presence of hydroids, sponges and bryozoans. Bellan-Santini (1998) lists 44 species from the coralligenous community (below $35 \mathrm{~m}$ depth), to which another 56 species collected from sciaphilic communities with Flabellia petiolata and Halimeda tuna have to be added. Therefore, a total number of 100 species is probably a good estimate of the amphipods thriving in coralligenous communities.

According to the available literature, common species include Maera inaequipes, M. grossimana, Liljeborgia dellavallei, Leptocheirus bispinosus, Gitana sarsi, Amphilochus picadurus, Colomastix pusilla, Iphimedia serratipes and Stenothoe tergestina. In coralligenous communities with some erect algae, the following species are also abundant: Orchomene humilis, Leptocheirus guttatus, Stenothoe dollfusi, Leucothoe venetiarum, Pseudoprotella phasma, Cressa cristata, C. mediterranea, Caprella acanthifera, Corophium sextonae, Dexamine thea, Leucothoe euryonyx, Aora spinicornis and Elasmopus vachoni. Few species (Harpinia ala, Tryphosella simillima, Uncionella lunata) have been collected solely in coralligenous communities (Bellan-Santini 1998).

\section{Isopoda}

Laubier (1966) and Hong (1980) report 14 species from coralligenous communities. Cymodoce truncata, Jaeropsis brevicornis, Paranthura nigropunctata, Synisoma sp., Gnathia maxillaris and Paragnathia formica seem to be relatively common species. 


\section{MEDITERRANEAN CORALLIGENOUS ASSEMBLAGES}

\section{Decapoda}

The density of decapods in coralligenous concretions is very high, the estimate being 170 individuals in $500 \mathrm{~g} \mathrm{dw}$ of Mesophyllum alternans (García-Raso \& Fernández Muñoz 1987). According to García-Raso et al. (1996), it is very difficult to distinguish characteristic species of the coralligenous community because the assemblages are very similar to those found in other communities where there is shelter (e.g., the rhizomes of Posidonia oceanica).

Alpheus dentipes, Athanas nitescens, Pilumnus hirtellus, Pisidia longicornis, Galathea bolivari, Cestopagurus timidus and Thoralus cranchii are considered to be the characteristic decapod crustaceans inhabiting the shallow coralligenous frameworks of Mesophyllum alternans in the southwestern Mediterranean, along with, in certain areas, Porcellana platycheles, Synalpheus hululensis and Calcinus tubularis (García-Raso 1988). The three species which account for most of the biomass of the decapod crustaceans in the shallow coralligenous communities of the southwestern Mediterranean use this environment in different ways. In Pilumnus hirtellus, the coralligenous habitat seems to be a recruitment site, where mainly juveniles are recorded. The whole life cycle of Alpheus dentipes takes place in the coralligenous concretions, whereas in Synalpheus hululensis the coralligenous habitat provides shelter only for reproductive individuals (García-Raso \& Fernández Muñoz 1987).

Other species of decapods frequently reported from coralligenous bottoms are Alpheus ruber, A. megacheles, Pilumnus spinifer, Pisa tetraodon, Galathea intermedia, Eurynome aspera, Macropodia czerniavskii, Inachus thoracicus, Processa macrophthalma, Periclimenes scriptus, Typton spongicola, Balssia gasti and Pisidia longimana (Laubier 1966, Hong 1980, Carbonell 1984, García-Raso 1988). Other large decapods that are usually found in coralligenous communities are Dromia personata, Palinurus elephas, Scyllarus arctus, Scyllarides latus and Homarus gammarus (Corbera et al. 1993).

In deep waters, the decapod fauna reported by García-Raso (1989) is different from that reported from shallow water coralligenous habitats. This author found a total of 30 species, with Pilumnus inermis, Galathea nexa and Euchirograpsus liguricus being the most abundant decapods in these kinds of bottoms from the southwestern Mediterranean.

\section{Pterobranchia}

Only one pterobranch, Rhabdopleura normani, is reported by Laubier (1966) living as an epibiont of bryozoans.

\section{Brachiopoda}

Brachiopod species usually inhabit small crevices and interstices within the concretionary masses of the coralligenous assemblages. Crania anomala, Argyrotheca cistellula, A. cordata, A. cuneata, Megathiris detruncata and Lacazella mediterranea are the brachiopods most commonly reported from coralligenous communities (Laubier 1966, Logan 1979, Hong 1980). Another two species, Megerlia truncata and Platidia davidsoni, which are more typical of the bathyal zone, are seldom collected from coralligenous habitats (Vaissière \& Fredj 1963, Gamulin-Brida 1967, Logan 1979).

Bryozoa

Bryozoans are very abundant in coralligenous communities: 67 species in Banyuls (Laubier 1966), 133 in Marseilles (Hong 1980), 113 in the Medes Islands (Zabala 1984) and 92 in Cabrera (Ballesteros et al. 1993). A tentative estimate of the total number of bryozoans that thrive in coralligenous bottoms according to these studies is around 170 species. 


\section{ENRIC BALLESTEROS}

According to Zabala (1986) four different aspects of the distribution of bryozoans can be distinguished in coralligenous communities. The main species mentioned below derive from the studies by Laubier (1966), Hong (1980), Zabala $(1984,1986)$ and Ballesteros et al. (1993).

1. The flat surfaces of the coralligenous platform are dominated by Pentapora fascialis and Myriapora truncata, which have Nolella spp., Aetea spp., Crisia spp., Scrupocellaria spp., Mimosella verticillata and Synnotum aegyptiacum as epibionts. Turbicellepora avicularis is very common overgrowing gorgonians, and Chorizopora brongniartii, Diplosolen obelium, Tubulipora plumosa, Puellina gattyae and Lichenopora radiata are common epibionts of other organisms. Other common species are Beania magellanica, B. hirtissima, Mollia patellaria, Schizomavella auriculata, Cellepora pumicosa, Plagioecia spp., Cellaria fistulosa and C. salicornioides.

2. Coralligenous walls have the species reported above but also Smittina cervicornis, Adeonella calveti, Chartella tenella, Cribilaria innominata, Schizomavella spp., Parasmittina tropica, Sertella spp., Caberea boryi and Spiralaria gregaria.

3. Cavities and overhangs of coralligenous outcrops reveal a bryozoan fauna that is almost identical to that present in semidark caves, with several species already reported above, along with Dentiporella sardonica, Brodiella armata, Turbicellepora coronopus, Rynchozoon bispinosum, Schizotheca serratimargo, Escharoides coccinea, Escharina vulgaris, Callopora dumerilii, Smittoidea reticulata, Cribilaria radiata, Hippomenella mucronelliformis, Crassimarginatella maderensis, C. crassimarginata, Buskea nitida, Celleporina spp., Prenantia inerma, Diaporoecia spp., Enthalophoroecia deflexa and Idmidronea atlantica.

4. A final group is made up of species that appear mainly in deep-water coralligenous habitats, below $50 \mathrm{~m}$ depth, and are composed of stenotherm species that are also very resistant to sedimentation: Figularia figularis, Escharina dutertrei, E. porosa, Onychocella marioni, Omaloseca ramulosa, Buskea dichotoma, Escharella ventricosa, Enthalophoroecia gracilis, Schizoporella magnifica, Mecynoecia delicatula, Idmidronea coerulea and Hornera frondiculata.

\section{Crinoidea}

Two crinoids have been reported from coralligenous habitats, the common Antedon mediterranea (Laubier 1966, Ballesteros et al. 1993) and A. bifida (Montserrat 1984).

\section{Ophiuroidea}

According to Tortonese (1965), Laubier (1966), Hong (1980) and Montserrat (1984), up to 17 species of ophiuroids have been reported from coralligenous communities. There are some species that can be considered as characteristic of these habitats, such as Ophioconis forbesii, Amphiura mediterranea and A. apicula (Tortonese 1965, Laubier 1966). Other brittlestars live entangled in gorgonians: Astropartus mediterraneus and Ophiacantha setosa. The commonest species, however, are Ophiothrix fragilis, Ophiopsila aranea, Amphiura chiajei, A. filiformis, Amphipholis squamata and Ophioderma longicaudum. Ophiocomina nigra, despite being a typical species of soft bottoms, is usually found in the small cavities containing sediment within coralligenous communities.

\section{Asteroidea}

Up to eight species of seastars have been reported from coralligenous bottoms (Tortonese 1965, Laubier 1966, Munar 1993). The most abundant species is the ubiquitous Echinaster sepositus. 


\section{MEDITERRANEAN CORALLIGENOUS ASSEMBLAGES}

Marthasterias glacialis and Hacelia attenuata are also common, while Ophidiaster ophidianus is only found in the southern, warmer areas of the Mediterranean.

\section{Echinoidea}

Fourteen species of sea urchins are reported from coralligenous communities (Tortonese 1965, Laubier 1966, Hong 1980, Montserrat 1984, Munar 1993). The most common species is Sphaerechinus granularis (Sartoretto 1996), which is an important bioeroder. Also common in deep waters are Genocidaris maculata and Echinus melo. Psammechinus microtuberculatus is usually hidden inside the cavities of coralligenous outcrops. Juveniles of Paracentrotus lividus (and Arbacia lixula) are sometimes found, but are never abundant. Centrostephanus longispinus is more abundant in the warmer areas of the Mediterranean and usually lives within coralligenous crevices (Pérès \& Picard 1958, Laborel 1960, Harmelin et al. 1980, Francour 1991). Finally, Echinocyamus pusillus is a ubiquitous and very small species that inhabits the small patches of sand and gravel inside the concretions.

\section{Holothurioidea}

The most commonly observed species of sea cucumber is Holothuria forskali, which can be rather abundant in some coralligenous platforms (Laubier 1966, Ballesteros \& Tomas 1999). However, the genus Cucumaria has several species that live endolithically (C. saxicola, C. planci, C. kirschbergii, C. petiti). Another four species typical of sandy and muddy habitats have also been reported (Tortonese 1965, Laubier 1966, Montserrat 1984): Holothuria tubulosa, H. mammata, Trachytyone tergestina and Stichopus regalis.

\section{Tunicata}

Ramos (1991) describes a high species richness of ascidians in coralligenous communities, the families Didemnidae and Polyclinidae being especially present. In fact, around $70 \%$ of ascidian fauna is present in the coralligenous community (82 species). According to Ramos (1991), the most characteristic species of the coralligenous community are Cystodites dellechiajei, Ciona edwardsi and Halocynthia papillosa, although other abundant species include Diplosoma spongiforme, Distaplia rosea, Trididemnum cereum, T. armatum and Polycarpa gracilis. Other species that are often collected from coralligenous communities are Distomus variolosus, Didemnum maculosum, Ecteinascidia herdmanni, Clavelina nana, Polysyncraton lacazei, P. bilobatum, Polycarpa pomaria, Pyura spp., Microcosmus polymorphus, M. sabatieri, Styela partita, Eudistoma planum, E. banyulensis, Pseudodistoma cyrnusense, Aplidium densum and A. conicum (Laubier 1966; Hong 1980; Turon 1990, 1993). Clavelina dellavallei and Rhodosoma verecundum seem to be especially abundant in the coralligenous concretions from the eastern Mediterranean (Pérès \& Picard 1958).

\section{Pisces}

The fish fauna from the coralligenous community includes many fishes covering a wide bathymetric range, such as Epinephelus marginatus, Sciaena umbra, Coris julis, Dentex dentex, Symphodus mediterraneus, S. tinca, Diplodus vulgaris, Apogon imberbis, Chromis chromis or Labrus merula. However, there is a group of species that are characteristic of coralligenous communities. Some of these, like Lappanella fasciata or Acantholabrus palloni, are species restricted to deep waters (Sartoretto et al. 1997), but others, such as Anthias anthias (Harmelin 1990), as well as (among the commonest species) Gobius vittatus, Phycis phycis and Labrus bimaculatus (Garcia-Rubies 1993, 1997), are easily observed during recreational diving. Other species are more abundant in 


\section{ENRIC BALLESTEROS}

coralligenous outcrops than in shallow waters, examples being Serranus cabrilla, Spondyliosoma cantharus, Diplodus puntazzo, Ctenolabrus rupestris, Spicara smaris, Scorpaena scrofa and Symphodus doderleini. Finally, Conger conger, Muraena helena, Zeus faber, Scorpaena notata, Scyliorhinus canicula and S. stellaris are also observed in the coralligenous habitat (Sartoretto et al. 1997, Ballesteros, personal observation).

The fish fauna inhabiting the small crevices of coralligenous concretions probably consists of fishes with cave-dwelling tendencies, although data are very scarce. Hong (1980) reports juveniles of Diplecogaster bimaculata and Gobius niger. According to Patzner (1999), cryptobenthic species, such as Thorogobius ephippiatus, T. macrolepis, Corcyrogobius liechtensteinii, Gammogobius steinitzii and Didogobius splechtnai, which are usually observed in caves, may also be present in the small holes of deep water coralligenous habitats. Odondebuenia balearica is another cryptobenthic fish that inhabits coralligenous communities but is rarely observed (Riera et al. 1993).

Studies of the fish fauna of the coralligenous habitat have obtained slightly different results when performed in different areas (Bell 1983; Harmelin 1990; Garcia-Rubies 1993, 1997; Ballesteros \& Tomas 1999). These differences should be related to biogeography or to differences in coralligenous rugosity. Symphodus melanocercus, for example, is a characteristic coralligenous species in Cabrera and other localities of the Balearic Islands, but it is a widespread species in terms of depth distribution in the northwestern Mediterranean (García-Rubies 1993).

\section{Endangered species}

Although it is very difficult to determine the conservation status of any marine species living in the relatively deep waters where coralligenous communities develop, several approaches to endangered species have been taken.

According to Boudouresque et al. (1990), at least eight species of macroalgae that live in coralligenous communities can be considered endangered: Chondrymenia lobata, Halarachnion ligulatum, Halymenia trigona, Platoma cyclocolpa, Nemastoma dichotomum, Ptilophora mediterranea, Schizymenia dubyi and Laminaria rodriguezii. However, this list can be greatly extended by adding species such as Aeodes marginata, Sphaerococcus rhizophylloides, Schmitzia neapolitana, Ptilocladiopsis horrida, Microcladia glandulosa, Rodriguezella bornetii, R. pinnata and Lomentaria subdichotoma (Ballesteros, unpublished data). Most of these species have coralligenous or maërl beds as their only habitats, and seem to be very sensitive to pollution and increased sedimentation rates (Boudouresque et al. 1990), two of the main threats to coralligenous assemblages. The case of Laminaria rodriguezii is especially relevant, as this species develops best in rhodolith beds, from where it has almost disappeared due to trawling activities; coralligenous bottoms now constitute its only refuge.

Several animal species in coralligenous habitats are also considered to be at risk (Boudouresque et al. 1991). Although none of them is in danger of extinction, local depletion of some species stocks may occur. Most of the endangered species have great commercial value and this is the main reason for their increased rarity.

Among the anthozoans, red coral (Corallium rubrum) is exploited commercially in almost all Mediterranean countries, and its stocks have strongly declined in most areas, particularly in shallow waters (Weinberg 1991). Populations of gorgonians common in coralligenous communities but which lack commercial value, such as Paramuricea clavata, Eunicella cavolinii and E. singularis, are pulled out inadvertently by recreational divers (Coma et al. 2004). The black coral, Gerardia savaglia, is a very rare species and can be a target for collection by divers, thus making the species even scarcer (Boudouresque et al. 1991).

Some species of molluscs living in coralligenous communities are also threatened. The edible rock-borer bivalve Lithophaga lithophaga is considered an endangered species (Boudouresque et al. 


\section{MEDITERRANEAN CORALLIGENOUS ASSEMBLAGES}

1991) despite being extremely abundant. Harvesting by divers is only important in shallow waters and the reason behind calls for the species to be protected is actually an attempt to protect the shallow benthic communities in rocky shores dominated by macroalgae (Russo \& Cicogna 1991, Hrs-Brenko et al. 1991), not the coralligenous bottoms themselves. Protection of the two species of fan mussels (Pinna nobilis and P. rudis) present in the Mediterranean has also been proposed (Boudouresque et al. 1991), because they have been decimated in northern Mediterranean areas by coastline modification and harvesting as souvenirs (Vicente \& Moreteau 1991). P. nobilis mainly grows in seagrass meadows, and its presence in coralligenous communities is very unusual (Vicente \& Moreteau 1991). However, P. rudis (= P. pernula) is frequently seen in coralligenous habitats, at least in the warmer areas of the western Mediterranean (Ballesteros 1998).

According to Templado (1991), neither of the two species of the genus Charonia that occur in the Mediterranean is threatened by extinction. C. lampas is rare in the northern Mediterranean but rather common in the southwest, whilst $C$. tritonis variegata has been recorded in the eastern and southwestern Mediterranean. Both species are collected and used for decorative purposes but Templado (1991) argues that indirect anthropogenic pressures (coastline development) are the main reason for its increased rarity, or even local extinction.

The sea urchin Centrostephanus longispinus is also considered an endangered species by Boudouresque et al. (1991), despite being a rare species in the northwestern Mediterranean, probably due to biogeographical reasons. No anthropogenic pressure has been proposed to explain its rarity.

The slipper lobster, Scyllarides latus, is highly appreciated gastronomically. The high market prices it obtains have stimulated increased fishing pressure, which has led to a dramatic decline in the abundance of this species in several areas of the Mediterranean (Spanier 1991). It is more common in the warmer Mediterranean areas (e.g., eastern Mediterranean, Balearic Islands), and rarest in the colder ones.

The dusky grouper, Epinephelus marginatus (= E. guaza), is the main target species in spearfishing activities and its abundance has greatly decreased in several Mediterranean areas, mainly in the north (Chauvet 1991). However, immature specimens and juveniles are very abundant in certain areas (e.g., Balearic Islands; Riera et al. 1998) and, therefore, the species is only threatened in those places where there is no regular recruitment (e.g., northwestern Mediterranean). Moreover, the recovery of this species in marine protected areas has repeatedly been reported (Bell 1983, GarciaRubies \& Zabala 1990, Francour 1994, Coll et al. 1999), as has reproduction (Zabala et al. 1997a,b), suggesting that adequate management can rapidly improve its situation in those areas where stocks continue to decline. Other groupers, such as E. costae (= E. alexandrinus), Mycteroperca rubra and Polyprion americanus (Riera et al. 1998; Mayol et al. 2000), are probably in a worse situation, as their population stocks are much lower than those of the dusky grouper.

Sciaena umbra and Umbrina cirrosa are the two other fish considered as endangered in the review by Boudouresque et al. (1991). Both can live in coralligenous communities, the former being more abundant. Although both species are easily spearfished, Sciaena umbra stocks readily recover after fishing prohibition (Garcia-Rubies \& Zabala 1990, Francour 1994).

Other species are not included in the list of Mediterranean endangered species by Boudouresque et al. (1991), although according to Mayol et al. (2000) they are exposed to major risk. This is the case of several small sharks inhabiting detritic and coralligenous habitats: Scyliorhinus stellaris, Mustelus asterias, M. mustelus, Squalus acanthias and S. blainvillei. All these species were very common in fish catches by Balearic Island fishermen at the beginning of the twentieth century, but are now extremely rare. Other species that can thrive in coralligenous communities and which are considered by Mayol et al. (2000) to be endangered are seahorses (mainly Hippocampus ramulosus), Gaidropsarus vulgaris and some cryptobenthic fishes (Didogobius splechtnai, Gammogobius steinitzii). These are not commercial species and their increased rarity may be related to indirect effects of fishing (such as cascading effects), physical disturbances of trawling or other unknown causes. 


\section{ENRIC BALLESTEROS}

\section{Biotic relationships}

\section{Spatial interactions, herbivory, carnivory}

Biotic relationships, both trophic ones and those related to spatial interactions, are a major force in structuring all ecosystems. In fact, the whole buildup of coralligenous frameworks is affected by the interactions between encrusting corallines and other sessile, invertebrate builders (Figures 16A,B). The final result (that is, what the framework looks like) is not only related to which builder has been the most effective but also to how the borers (from sea urchins to excavating sponges and polychaetes) have subsequently changed the structure. Biotic relationships at this level are, therefore, crucial in building coralligenous assemblages.

Trophic relationships are especially interesting in coralligenous communities because the main organisms are not easily edible. Most of them have skeletons that contribute to structure but which also deter feeding (Zabala \& Ballesteros 1989). Others may have chemical defences that make them unpalatable or even toxic (Martí 2002). Most of the largest sessile invertebrates living in coralligenous communities do not feed directly upon other animals from the coralligenous assemblage but rather on the pelagic system. In fact, the largest part of the living biomass in coralligenous assemblages consists of algae and suspension feeders (True 1970, Zabala \& Ballesteros 1989), which suggests that herbivory and carnivory are not as important as in other marine Mediterranean environments. The low dynamism of coralligenous habitats (Garrabou et al. 2002) also supports this suggestion.
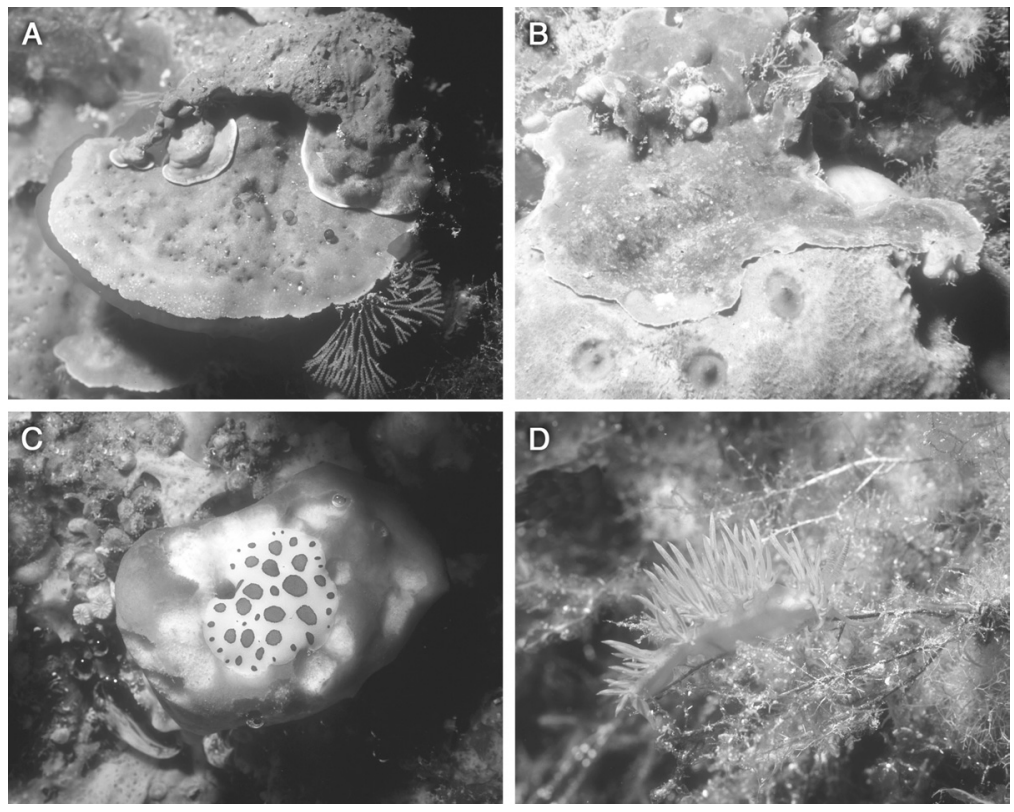

Figure 16 (See also Colour Figure 16 in the insert.) Spatial interactions are crucial in the buildup of coralligenous assemblages. (A) Mesophyllum alternans overgrows Lithophyllum cabiochae which, in its turn, is epiphytised by the small green alga Halicystis parvula (above) and a tunicate (below); (B) Lithophyllum frondosum overgrows sponge Ircinia oros. Strong prey selection is present in the coralligenous community.

(C) Opisthobranch Discodoris atromaculata feeds almost exclusively on sponge Petrosia ficiformis;

(D) Opisthobranch Flabellina affinis feeds on hydrozoans of the genus Eudendrium. (Photos by the author.) 


\section{MEDITERRANEAN CORALLIGENOUS ASSEMBLAGES}

However, both herbivory and carnivory are relevant to coralligenous communities. The sea urchin Sphaerechinus granularis is a major browser of encrusting corallines (Sartoretto \& Francour 1997), and several invertebrates (opisthobranchs, amphipods, copepods) are able to feed on the green alga Halimeda (Ros 1978). Examples of carnivores include most of the fishes that thrive in coralligenous communities, as well as most prosobranchs, echinoderms, vagile polychaetes and crustaceans. Although feeding by most animals is not selective, there are some noteworthy examples of animals that have a strong prey selection. These include the well-known cases of the opisthobranch Discodoris atromaculata, which feeds on the sponge Petrosia ficiformis (Figure 16C), and the other opisthobranch Flabellina affinis, which feeds mainly on hydrozoans of the genus Eudendrium (Figure 16D) (Ros 1978). Other interesting examples have recently been reported for copepods of the genus Asterocheres, which systematically feed on both rhagons and adult sponges by sucking the material produced at the ectosome of the sponge (Mariani \& Uriz 2001).

\section{Chemical ecology}

The production of active substances in benthic organisms plays a major role in structuring benthic communities. Some of these substances act as a defence against consumers (e.g., unpalatable or repellent substances) while others mediate the interactions between species regarding the occupation of space (Martí 2002). Sponges, bryozoans and tunicates are the taxa with the largest number of species producing active substances (Uriz et al. 1991). The lower side of coralligenous blocks, as well as semidark caves and overhangs, exhibits the highest percentage of active species of all the Mediterranean communities sampled by Uriz et al. (1991), suggesting that investment in production of allelochemicals plays an important role in space competition in coralligenous assemblages (Figure 17A).

\section{Epibiosis, mutualism, commensalism, parasitism}

There are innumerable relationships between species in coralligenous communities that can be described as 'associations', and these may or may not involve trophic transfer. Sometimes it is difficult to differentiate between them because the natural history of the species, or the benefits and costs of the components of the association, are unknown or not clearly understood. The purpose here is not to review these associations, nor to mention all those which have been described for coralligenous communities, but to report some examples of epibiosis, mutualism, commensalism and parasitism that can give an idea of the complexity of the coralligenous community with respect to these kinds of relationships.

Epibiosis is a widespread phenomenon in benthic communities and coralligenous assemblages are an excellent example of the different strategies adopted by organisms to cope with this problem (True 1970). Some basibionts tolerate different degrees of epibiosis and even almost complete overgrowth, whilst others have developed antifouling defences to avoid overgrowth. Both types of strategies can be displayed by species from the same zoological group living in coralligenous communities. For example, the ascidians Microcosmus sabatieri and Pyura dura are usually completely covered by a wide array of epibionts, whilst Halocynthia papillosa and Ciona edwardsi are always free of overgrowing organisms (Ramos 1991).

Some epibionts are considered to select their hosts, whilst others are not selective. The anthozoan Parerythropodium coralloides usually grows over the axes of gorgonians (Eunicella, Paramuricea clavata), although it can also grow over other animals and seaweeds, or be attached to rubble or any other kind of substratum (Laubier 1966, Gili 1986). The anthozoan Parazoanthus 


\section{ENRIC BALLESTEROS}
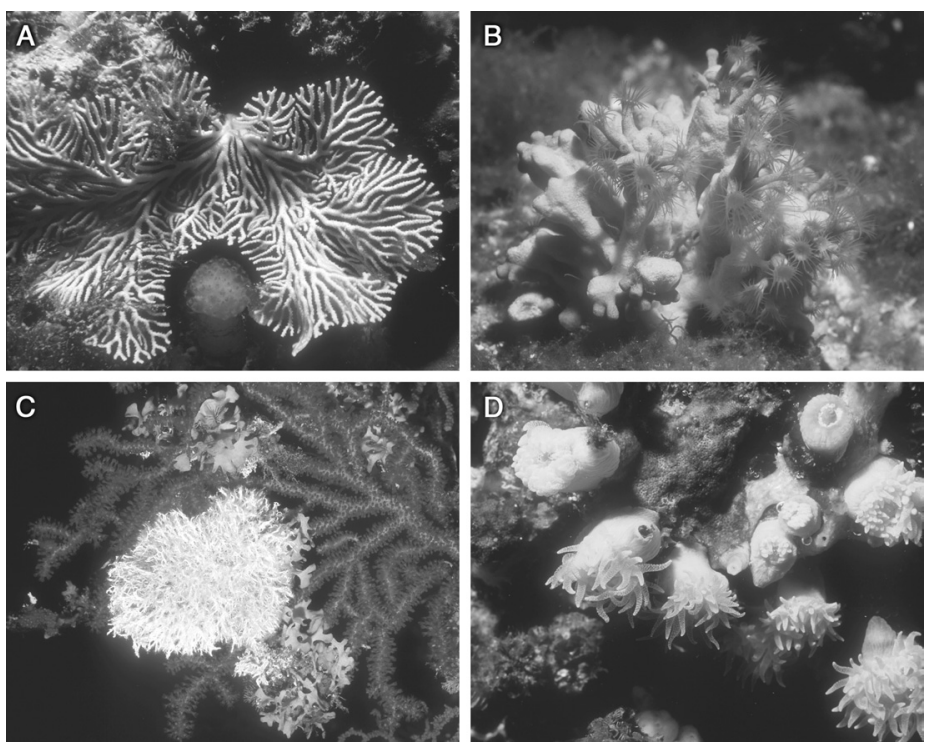

Figure 17 (See also Colour Figure 17 in the insert.) (A) Space competition can also be mediated by trophic depletion of the surrounding waters, or by allelochemicals. Tunicate Pseudodistoma cyrnusense inhibits growth of bryozoan Hornera frondiculata; (B) Zoantharian Parazoanthus axinellae is usually a selective epibiont of sponge Axinella damicornis; (C) Nonselective epibionts overgrow the gorgonian Paramuricea clavata: the worm Salmacina dysteri and the bryozoan Pentapora fascialis; (D) The barnacle Pyrgoma anglicum living inside the anthozoan Leptopsammia pruvoti can be considered a case of parasitism. (Photos by the author.)

axinellae prefers sponges of the genus Axinella (mainly A. damicornis) (Figure 17B), but it can also grow over other sponges or over rock or encrusting corallines (Gili 1986). The bryozoan Turbicellepora avicularis prefers the basal parts of the axes of gorgonians Paramuricea clavata and Eunicella spp. (Laubier 1966, Zabala 1986).

The number of species able to act as nonselective epibionts in coralligenous communities is huge because most of the space is occupied and larvae usually have to settle on living animals or plants. Therefore, almost all sessile species can be epibionts (True 1970) (Figure 17C). Gautier (1962), for example, reviewed the epibiosis of bryozoans over bryozoans in coralligenous assemblages, and Nikolic (1960) reported up to 18 species growing over Hippodiplosia foliacea in a coralligenous framework in the Adriatic Sea. Of particular interest are the observations by Laubier (1966) on some heterotrichs (Protozoa) of the family Folliculinidae that live close to the zooid mouth of different species of bryozoans or even inside its empty zooids. Laubier (1966) reported up to six species of Folliculinidae living as epibionts of bryozoans in the coralligenous communities of Banyuls.

Mutualism has been reported, for example, in the case of the scyphozoan Nausitoë punctata and several horny sponges (Uriz et al. 1992b). Cacospongia scalaris, Dysidea avara and D. fragilis utilize the thecae of Nausitoë punctata as a substitute for skeletal fibres, presumably reducing metabolic costs associated with skeleton building. The scyphozoan should thus benefit from greater protection against predation and mechanical disturbance, trophic advantages (inhalant flow carries out small particles susceptible to capture by the scyphozoan), and chemical defence against predators, as the three species of sponges exhibit toxicity (Uriz et al. 1992c).

Commensalism is one of the most common relationships in coralligenous communities. Most relationships are considered as commensalism because they lack unequivocal parasitic features, as in the case of the polychaete Eunice siciliensis and the decapods Alpheus dentipes and Typton 


\section{MEDITERRANEAN CORALLIGENOUS ASSEMBLAGES}

spongicola, which live as endobionts of the boring sponge Cliona viridis (Laubier 1966). Another well-known example is that occurring between $C$. viridis and the likewise boring polychaete Dipolydora rogeri (Martin 1996). The curious feature of this association is that it persists even when the sponge is massive and nonexcavating. The feeding activity of the polychaete is favoured by the inhalant flow of the sponge and, moreover, the sponge offers physical protection to the worm when they are not embedded within the calcareous algae. The ability of the worm to manipulate relatively large particles (either to feed or to build its tubes) may favour the filtering activity of the sponge by cleaning the area around the inhalant papillae, thus preventing the collapse of their orifices (Martin \& Britayev 1998).

Polychaetes of the genus Haplosyllis are well-known commensalists (Martin \& Britayev 1998). Up to 200 specimens of Haplosyllis spongicola have been found in $1 \mathrm{~cm}^{2}$ of sponge (Bacescu 1971), and thus sponges merit the description of 'living hotels'. Another case is the polychaete Haplosyllis depressa chamaeleon, which lives exclusively as a commensal of the sea fan Paramuricea clavata, where it crawls above the living colonies (Laubier 1960, 1966).

The barnacle Acasta spongites lives inside the sponge Ircinia variabilis, as well as other sponges (Laubier 1966, Rützler 1976, Uriz et al. 1992b); it can be considered as a parasite because the cirripede settles into the inhalant oscula of the sponge, rendering it useless. Another barnacle, Pyrgoma anglicum, is quite often found living inside the anthozoan Leptopsammia pruvoti (Figure 17D). A further example of parasitism in coralligenous communities is found in the two boring spionid polychaetes Dipolydora armata and Polydora hoplura and the bryozoans Dentiporella sardonica, Porella concinna, Brodiella armata and Schizomavella auriculata (Laubier 1959a, 1959b). The bryozoans are infested throughout their basal layer and polychaetes excavate galleries that reach the surface of the colony or modify the growth form of the bryozoan in such a way that the polychaete tubes are composed of host zooids. In both cases the bryozoan is stimulated to build calcareous formations around the end of the polychaete tubes, facilitating the feeding behaviour of the worm and protecting it (Laubier 1966).

\section{Processes}

\section{Growth and age of coralligenous frameworks}

The mean growth rate of pillars of Mesophyllum alternans (reported as M. lichenoides) in La Ciotat (NW Mediterranean) has been estimated by radiocarbon dating to be $0.19 \mathrm{~mm} \mathrm{yr}^{-1}$ (Sartoretto 1994), with a range of 0.11 to $0.26 \mathrm{~mm} \mathrm{yr}^{-1}$. Similar values of $0.16 \mathrm{~mm} \mathrm{yr}^{-1}$ over the last $640 \mathrm{yr}$ were obtained in a coralligenous block sampled at $15 \mathrm{~m}$ in the Natural Reserve of Scandola (Corsica) (Sartoretto et al. 1996).

Ages obtained by radiocarbon dating of coralligenous frameworks situated at depths between 10 and $60 \mathrm{~m}$ in the northwestern Mediterranean range from $640 \pm 120 \mathrm{yr}$ before the present (BP) to $7760 \pm 80 \mathrm{yr}$ BP (Sartoretto et al. 1996). Internal erosion surfaces within the concretions provide evidence of discontinuous development. The accumulation rate of the coralligenous constructions is very low $\left(0.006-0.83 \mathrm{~mm} \mathrm{yr}^{-1}\right)$ and oscillates greatly according to depth and time period. The highest accumulation rates $\left(0.20-0.83 \mathrm{~mm} \mathrm{yr}^{-1}\right)$ have been recorded for deep coralligenous frameworks and correspond to a period between 8000 and $5000 \mathrm{yrs}$ BP. After $5000 \mathrm{yr}$ BP, the only appreciable accumulation rates $\left(0.11-0.42 \mathrm{~mm} \mathrm{yr}^{-1}\right.$ ) have been recorded for coralligenous frameworks situated in relatively shallow waters (10-35 m depth), whereas the accumulation rates of concretions below a depth of $50 \mathrm{~m}$ is almost nil. Thus, the development of these deep coralligenous formations occurred a long time ago, when the depth of the overlying layer of water probably did not exceed 10-15 m, and since their period of settlement (8500-7000 yr BP) the accumulation rate has progressively declined. This decrease in accumulation rates can no doubt be explained by the 


\section{ENRIC BALLESTEROS}

stable, but rather unfavourable, environmental conditions resulting from the decrease in irradiance related to increased water depth. It is also worth noting that the coralligenous frameworks below a depth of $30 \mathrm{~m}$ in the Marseilles area are today inactive and almost devoid of living coralline algae. In contrast, those present in Corsica at a depth of $50 \mathrm{~m}$ and below (down to $65 \mathrm{~m}$ ) are completely covered by living corallines and are in an active period of growth; this difference must be related to the clear waters present in Corsica.

\section{Carbonate production}

Although there are no specific studies on the carbonate production of the coralligenous community on a yearly basis, Canals \& Ballesteros (1997) estimated the carbonate production of the phytobenthos in the coralligenous and other communities from the continental shelf of the Balearic Islands, taking into account the standing crop of calcareous algae and their $\mathrm{P} / \mathrm{B}$ ratios. The coralligenous community thriving in relatively shallow waters (with Mesophyllum alternans and Halimeda tuna as dominant algae) was the one with the highest production (around $465 \mathrm{~g} \mathrm{CaCO}_{3} \mathrm{~m}^{-2}$ $\mathrm{yr}^{-1}$ ). Production of deep water coralligenous concretions dominated by Lithophyllum cabiochae was much lower (around $170 \mathrm{~g} \mathrm{CaCO}_{3} \mathrm{~m}^{-2} \mathrm{yr}^{-1}$ ), but even this rate is much higher than average carbonate production for the Balearic shelf as a whole $\left(100 \mathrm{~g} \mathrm{CaCO}_{3} \mathrm{~m}^{-2} \mathrm{yr}^{-1}\right)$. The contribution of suspension feeders to the total carbonate production of coralligenous communities in the Balearic shelf, as well as in other Mediterranean areas, is practically unknown. However, estimates of the animal carbonate production in deep water (25-50 m depth) rocky bottoms from the Alboran Sea (southwestern Mediterranean), mainly dominated by big suspension feeders with calcareous skeletons (predominantly the coral Dendrophyllia ramea, the bryozoans Pentapora fascialis, Smittina cervicornis and Myriapora truncata, and polychaetes such as Salmacina dysteri, Protula sp. and other serpulids), are very high (around $660 \mathrm{~g} \mathrm{CaCO}_{3} \mathrm{~m}^{-2} \mathrm{yr}^{-1}$ ) (Cebrian et al. 2000). Although the combination of highly productive calcareous animals in these bottoms is unusual in other Mediterranean areas, this figure can be considered as the upper limit for animal carbonate production in the coralligenous habitat.

\section{Bioerosion}

The most active browser in the coralligenous community is the sea urchin Sphaerechinus granularis, which accounts for a large part of the total coralligenous erosion. Sartoretto \& Francour (1997) calculated an erosion rate ranging between 16 and $210 \mathrm{~g} \mathrm{CaCO}_{3} \mathrm{~m}^{-2} \mathrm{yr}^{-1}$, with higher values in shallow waters and lower values in coralligenous concretions around $50 \mathrm{~m}$ depth. The bioerosional role of Echinus melo cannot be measured, but it is very low.

Among macroborers the spionid polychaetes Polydora spp. and the mollusc Hyatella arctica are the only macrofauna that colonise experimental blocks after $1 \mathrm{yr}$ of exposure (Sartoretto 1998). In this study, the total erosion caused by annelids and molluscs increases with the number of individuals but does not exceed $5.73 \pm 0.77 \mathrm{~g} \mathrm{CaCO}_{3} \mathrm{~m}^{-2}$ at $20 \mathrm{~m}$ and $1.50 \pm 0.99 \mathrm{~g} \mathrm{CaCO}_{3} \mathrm{~m}^{-2}$ at $60 \mathrm{~m}$ after $1 \mathrm{yr}$. In natural communities macroborers are more abundant (excavating sponges, Sipunculida, perforating molluscs) and their absence in the experimental substrata may be due to their slow growth and to the high spatial and temporal variability of larval recruitment (Kleeman 1973).

The comparative erosion rates produced by the three main types of eroding organisms (browsers, microborers and macroborers) have been estimated by Sartoretto (1996). Sea urchins account for roughly $95 \%$ of the total mass of $\mathrm{CaCO}_{3}$ eroded. Bioerosion by micro- and macroborers accounts for the remaining $5 \%$, that of microborers being very low due to the great depths at which 


\section{MEDITERRANEAN CORALLIGENOUS ASSEMBLAGES}

coralligenous frameworks develop, and the high sedimentation rates, factors that prevent any significant development of microborers (Sartoretto 1998). Bioerosion by macroborers is probably underestimated because the studies of Sartoretto (1998) do not take into account several organisms that are common in coralligenous communities, in particular the bivalve Lithophaga lithophaga and excavating sponges (Sartoretto et al. 1996). The overall range of bioerosion observed in the coralligenous community is between $220 \mathrm{~g} \mathrm{CaCO}_{3} \mathrm{~m}^{-2} \mathrm{yr}^{-1}$ in relatively shallow waters and $20 \mathrm{~g}$ $\mathrm{CaCO}_{3} \mathrm{~m}^{-2} \mathrm{yr}^{-1}$ at a depth of $60 \mathrm{~m}$. This range is in agreement with the structure and age of coralligenous frameworks situated below $50 \mathrm{~m}$ depth in the region of Marseilles (Sartoretto 1996), and are at least one order of magnitude below the bioerosion experimentally estimated in coral reefs (Chazottes et al. 1995).

\section{Sedimentation}

The rugosity of coralligenous frameworks promotes the deposition of particles that take part in the buildup of the coralligenous structure through complex processes of lithification (Marshall 1983). However, high sedimentation rates can be a problem because sediment particles may cover the thalli of the encrusting corallines and screen them against light (Laborel 1961), as well as prevent the recruitment of new plants (Sartoretto 1996). Not all the sediment particles deposited in the coralligenous structure are included in the concretion; indeed, many of them are eliminated by different browsers, while others are resuspended by currents, organisms and gravitation. The rugosity of different coralligenous types is different, as is the capacity for sediment retention. The amount of water movement is also important, and this usually decreases with depth. Studies conducted by Sartoretto (1996) in the Marseilles region conclude that around $9 \mathrm{~kg} \mathrm{~m}^{-2} \mathrm{yr}^{-1}$ is retained in the coralligenous concretions situated at a depth of between 30 and $60 \mathrm{~m}$, while the retention in shallow waters is much lower. However, daily sedimentation rates are extremely high in shallow waters $\left(\sim 500 \mathrm{~g} \mathrm{~m}^{-2}\right)$ and much lower in deep waters (between 10 and $\left.35 \mathrm{~g} \mathrm{~m}^{-2}\right)$ (Sartoretto 1996).

The sediment that is finally incorporated into the coralligenous framework by a process of lithification has a large calcareous component of organisms living in the coralligenous community. Major contributors are coralline algae (57\%), bryozoans (19\%), molluscs (16\%), corals and serpulids (3\% each) (Laubier 1966).

\section{Dynamics and seasonality}

The study of dynamics for the whole coralligenous community is a very difficult task and has only very recently been undertaken. Garrabou et al. (2002) used a photographic method to look for changes occurring in two monitored areas of coralligenous concretions covering $310 \mathrm{~cm}^{2}$ over a period of $2 \mathrm{yr}$. The rate of change observed averaged $10 \% \mathrm{month}^{-1}$, with very low to nil seasonality. Most of the area (>70\%) remained almost constant throughout the $2 \mathrm{yr}$ of monitoring, showing no or few transitions, and this indicates the great persistence of the animals and plants that thrive in coralligenous communities (Figure 18).

Other studies have been conducted with some components or species of coralligenous communities. In fact, most studies dealing with the biology of the main species in coralligenous communities (see next section) have described the effects of seasonality, when this process exists.

In terms of benthic flora, Ballesteros (1991a) described the seasonal cycle of several phytobenthic communities from the northwestern Mediterranean, making a between-community comparison using the same variables as descriptors. The coralligenous community with Mesophyllum alternans and Halimeda tuna had the lowest seasonality of all the subtidal communities studied, this being almost constant in autumn, winter and spring, but with peak productivity in summer, 


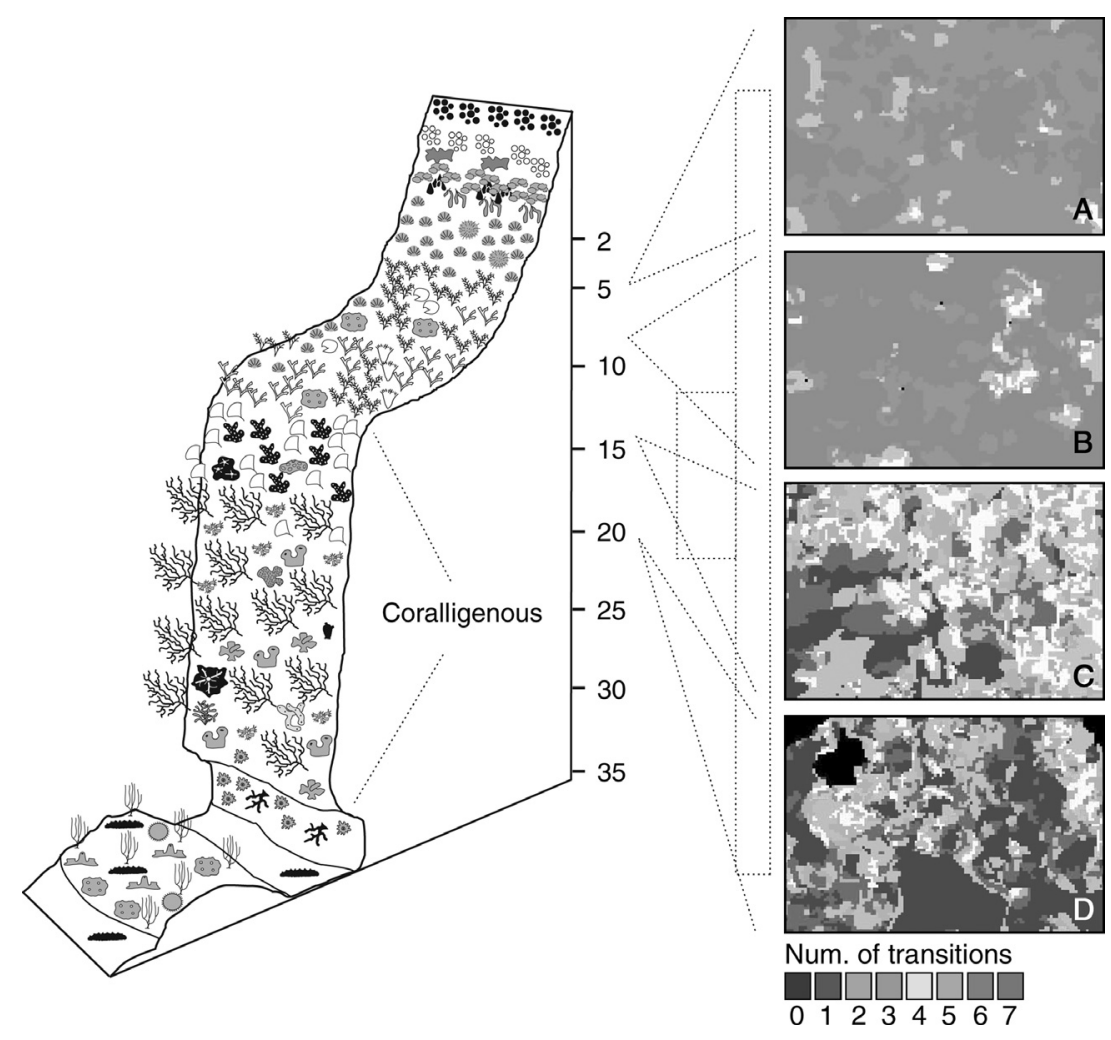

Figure 18 (See also Colour Figure 18 in the insert.) Maps of transition intensity resulting from overlay procedures of images from the same plot $\left(310 \mathrm{~cm}^{2}\right)$ along a depth gradient in a vertical wall at the Medes Islands (NE Spain) during $2 \mathrm{yr}$ of sampling. Patch colour denotes number of changes taking place in each patch (see legend). Coralligenous communities (14 and $20 \mathrm{~m}$ depth) display much lower transition rates than shallow water communities, indicating high persistence and low rates of change in the animals and plants thriving in the coralligenous communities. (From Garrabou et al. 2002. With permission from Elsevier.)

during which time there were higher biomass values than for the rest of the year. Piazzi et al. (2004) found significant seasonal differences that were mostly related to the disappearance of many turf species and the decrease in cover of most erect algae, principally foliose and corticated-terete forms, in winter. Although growth of coralline algae is almost constant throughout the year (Garrabou \& Ballesteros 2000), Halimeda growth occurs mainly in summer (Ballesteros 1991c). In terms of structural changes in the community, two stages can be discerned over an annual cycle: a diversified community stage, with a reduced coverage of Halimeda and other soft algae, and a developed community stage, characterized by a high coverage of Halimeda (Ballesteros 1991b). The shift from the diversified community stage to the developed community stage takes place through a production phase (early summer). A diversification phase can be distinguished in late autumn, when a sudden fall in Halimeda coverage is detected (Ballesteros 1991b) (Figure 19).

Most benthic hydrozoans exhibit a seasonal pattern, with reproduction in spring or autumn and growth from autumn to spring; most of them disappear during the summer, leaving only dormant basal stolons (Boero et al. 1986). Epiphytic hydrozoans on Halimeda tuna decline in abundance in summer because of the death of old thalli of Halimeda, the growth of new thalli and apical articles on existing thalli, and possibly because of interspecific competition with epiphytic algae (Llobet et al. 1991a). 


\section{MEDITERRANEAN CORALLIGENOUS ASSEMBLAGES}

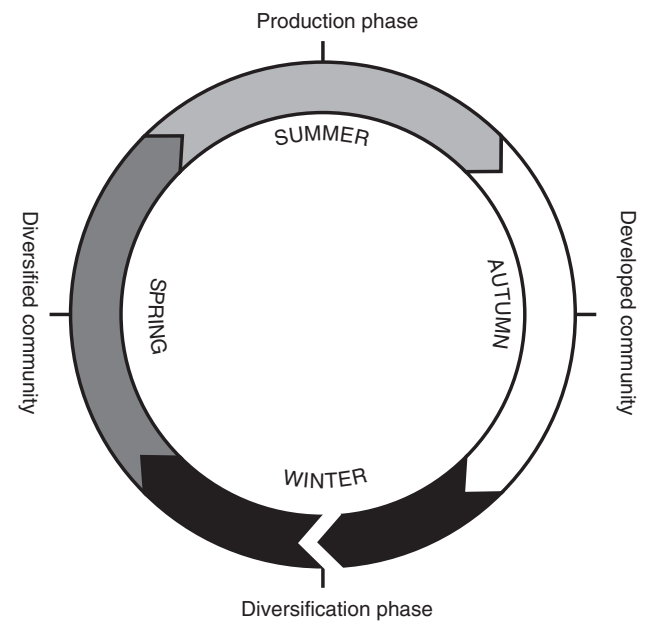

Figure 19 Although seasonality in structural patterns is not very evident in coralligenous communities, assemblages of the green alga Halimeda tuna show high production in summer, higher biomass in autumn, low production in winter and high spatial heterogeneity in spring, going through the two stages of a diversified community (spring) and a developed community (autumn). (From Ballesteros 1991a.)

Anthozoans exhibit a marked seasonality in all activities (Coma et al. 1998a, Garrabou 1999). According to Coma et al. (2002) respiration rates of Paramuricea clavata, Dysidea avara and Halocynthia papillosa vary two- to three-fold across the annual cycle, exhibiting a marked seasonal pattern but showing no daily cycle or significant day-to-day variability within months. The respiration rate of Paramuricea (a passive suspension feeder) does not correlate with temperature, but that of Dysidea and Halocynthia (active suspension feeders) increases with temperature. There is a low rate of new tissue synthesis during summer, together with the contraction of polyps and a low $\mathrm{Q}_{10}$, which explains the low respiration rates of Paramuricea observed during the period of highest temperature. These low respiration rates support the hypothesis that energy limitations may underlie summer dormancy in some benthic suspension-feeding taxa in the Mediterranean (Figure 20).

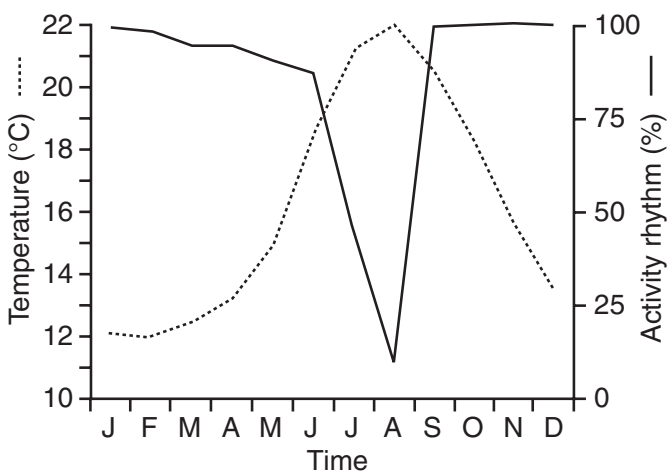

Figure 20 Activity rhythm in the gorgonian Paramuricea clavata, estimated as a percentage of expanded colonies, displays a strong decrease in summer, in conjunction with high water temperatures. This, and other evidence of decreased activity (i.e., growth and reproduction), in Paramuricea, as well as in other suspensionfeeders, prompted Coma et al. (2002) to describe summer dormancy for many Mediterranean benthic invertebrates. (From Coma et al. 1998a. With permission from Inter-Research.) 


\section{ENRIC BALLESTEROS}

There is growing evidence that seasonal patterns of activity and secondary production of suspension feeders in coralligenous assemblages are characterized by aestivation (Coma et al. 2000). Several types of resting and resistance periods have been observed in several colonial ascidians in the warm season (Turon 1992, Turon \& Becerro 1992). In the case of Polysyncraton lacazei the surface of the colonies is covered by a glassy pellicle and the siphonal apertures are sealed. This state is interpreted as a rejuvenative phenomenon that extends the life span of the zooids (Turon 1992). Some sponges also go through a resting, nonfeeding period with cellular restructuring, mainly in summer. For example, some specimens of Crambe crambe appear to be covered by a glassy cuticle, obliterating the oscula and ostia after reproduction, from the end of August until the end of October (Turon et al. 1999). These authors suggest that these resting stages develop not only in response to remodelling following reproduction, but also as an effect of water temperature abnormalities.

The decapod fauna also displays a certain seasonality (García-Raso \& Fernández Muñoz 1987), due to the intense recruitment of several species in late summer, and a progressive decrease in the density of individuals and an increase in their size from October to June.

The fish fauna of coralligenous communities is also affected by seasonality (Garcia-Rubies 1997), although its effect is of very minor importance. The number of species in fish counts along $50 \mathrm{~m}$-long visual transects of the coralligenous bottoms around the Medes Islands slightly decreases in winter, and most fishes seem to be less active than in summer.

\section{Functioning of outstanding and key species}

Several studies of coralligenous concretions are devoted to species that are particularly abundant, are architecturally important or are economically valuable. A compilation of the major knowledge of these species is presented here.

\section{Coralline algae}

Growth dynamics of two important coralligenous builders in the northwestern Mediterranean, Mesophyllum alternans and Lithophyllum frondosum, were studied in the bioconcretions of the Medes Islands marine reserve, in a steep wall situated at a depth of between 15 and $30 \mathrm{~m}$ (Garrabou \& Ballesteros 2000). Growth rates ranged from 0.16 month $^{-1}$ for Mesophyllum alternans to 0.09 month $^{-1}$ for Lithophyllum frondosum, with shrinkage rates being 0.09 and $0.04 \mathrm{month}^{-1}$, respectively. These growth rates are more than one order of magnitude lower than those reported for other Mediterranean and tropical coralline species, but similar to reports for crustose corallines in Arctic and temperate waters. No seasonal pattern in growth or shrinkage was found for either species, although seasonality in conceptacle occurrence was detected in Lithophyllum frondosum, with a high interannual variability. Mesophyllum alternans thalli frequently underwent fissions and fusions (almost one event during the 2-yr monitoring period for $50 \%$ of monitored plants), while they were rarely observed in Lithophyllum frondosum. These differences in growth, shrinkage, and fission and fusion events are interpreted as different growth strategies. Mesophyllum alternans has a more opportunistic strategy, growing faster and gaining area more rapidly, although it also loses area at higher rates. Lithophyllum frondosum has a more conservative strategy and is more effective in maintaining the area acquired through its reduced growth rate (Garrabou \& Ballesteros 2000).

\section{Halimeda tuna}

Growth and production of a Halimeda tuna population from a coralligenous community (18 m depth) in the northwestern Mediterranean was studied by Ballesteros (1991c). The production of new segments changed seasonally, being maximal in summer and minimal in winter (Figure 21), 


\section{MEDITERRANEAN CORALLIGENOUS ASSEMBLAGES}

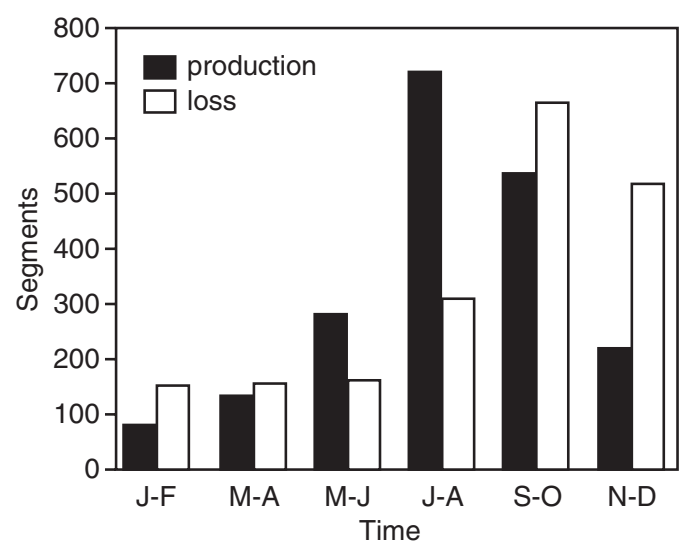

Figure 21 Seasonal changes in segment production and loss for a population of the green alga Halimeda tuna at $18 \mathrm{~m}$ depth in a coralligenous wall off Tossa de Mar (NE Spain). (From Ballesteros 1991c. With permission from Walter de Gruyter GmbH \& Co. KG.)

and this suggests that growth is mainly related to temperature and irradiance. The loss of segments seemed to be related to physical disturbances (storms) and herbivory. Annual production of H. tuna

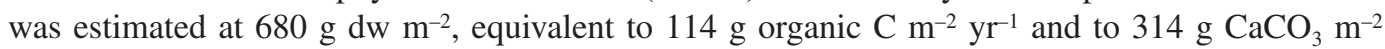
$\mathrm{yr}^{-1}$; the yearly $\mathrm{P} / \mathrm{B}$ ratio was $1.87 \mathrm{yr}^{-1}$. The epiphytic assemblage growing on the segments of $H$. tuna also displayed high seasonality, with a maximum biomass and species richness in early summer. Values of growth and production reported in Ballesteros (1991c) emphasize the importance of $H$. tuna as a producer both of organic matter and calcium carbonate in the coralligenous habitat. In fact, available data suggest that calcium carbonate production by Halimeda in shallow coralligenous concretions is similar to that of coralline algae (Canals et al. 1988).

\section{Porifera}

Garrabou \& Zabala (2001) studied the growth dynamics of four demosponges (Crambe crambe and Hemimycale columella from a 'precoralligenous' community, and Oscarella lobularis and Chondrosia reniformis from a coralligenous community in the Medes Islands), and reported relatively slow growth dynamics with low growth and shrinkage rates. The coralligenous species had an average relative growth rate of 0.15 month $^{-1}$ (Oscarella) and 0.022 month $^{-1}$ (Chondrosia), with shrinkage rates of 0.12 and 0.017 month $^{-1}$, respectively. Interspecific differences in growth, shrinkage, division and fusion rates were interpreted as evidence of distinct biological strategies aimed at persistence and the occupation of substratum. Chondrosia reniformis is conservative, with slow growth but great resistance to damage. Crambe crambe seems to enhance its rate of space occupation by a high division rate. Hemimycale columella grows quickly and shrinks at low rates, thus spreading rapidly over the substratum. Oscarella lobularis grows and shrinks rapidly, showing great overall growth.

Dysidea avara, a common sponge in coralligenous communities (Uriz et al. 1992a) obtained $85 \%$ of its ingested carbon from the fraction $<5 \mu \mathrm{m}$ (mostly procaryotes and pico- and nanoplankton) and $15 \%$ from the fraction $>5 \mu \mathrm{m}$ (mostly phytoplankton) (Ribes et al. 1999b). However, the partial contributions of the different groups varied seasonally, in accordance with the planktonic composition of the water column. During winter, phytoplankton was an important component of the total uptake $(26 \%)$, whereas during the rest of the year it contributed $<7 \%$ of the total uptake. This trophic plasticity may represent an advantage for the species because it attenuates the effects of 


\section{ENRIC BALLESTEROS}

seasonal fluctuations in the planktonic community. Moreover, the water transport rates of $63 \mathrm{ml} \mathrm{g}^{-1}$ $\mathrm{min}^{-1}$ and the high clearance rates for particles measuring $4 \mu \mathrm{m}$ or less observed in D. avara (Turon et al. 1997) point to a significant grazing impact of sponges on the picoplankton in communities like the coralligenous, where D. avara and other massive sponges are abundant (Laubier 1966; Bibiloni et al. 1984).

\section{Hydrozoa}

The hydrozoan Orthopyxis crenata, a common hydroid growing on the alga Halimeda tuna, was most abundant from November to April, when three cohorts were identified (Llobet et al. 1991b). During the rest of the year only two cohorts were identifiable, except in June and July when there was only one (juvenile) cohort. Reproduction took place from late October to early December, with recruitment occurring at the same time. In winter, colony sizes quintupled and tripled every 15 days, living a maximum of $6 \mathrm{wk}$. The maximum abundance of hydroids in winter seems to be related to increased food availability, a decrease in competence by epiphytic algae and a decline in the turnover rate of Halimeda (Ballesteros 1991c). The strategy of Orthopyxis crenata and other hydroids is completely different to that of long-living anthozoans that are also common in coralligenous communities; the colonies survive for only a small number of weeks but asexual reproduction by the creeping stolons ensures colony survival beyond the life of Halimeda thalli, and perhaps indefinitely.

Coma et al. (1992) studied the life cycle of two similar species of hydrozoans living over the thalli of $H$. tuna and also found that survival should be very long for each colony, due to the active asexual reproduction (by stolonisation in Halecium petrosum; by planktonic propagules in H. pusillum) that occurs throughout most of the year. Maximum life span of colonies was estimated to be only $8 \mathrm{wk}$, mean colony sizes increasing between three- and six-fold over consecutive 2-wk periods.

\section{Corallium rubrum}

Red coral (Corallium rubrum) is typically associated with the animal dominated communities growing in dim light conditions and which characterize smaller cavities, vertical cliffs and overhangs present in coralligenous concretions. Although it is predominantly found in the western basin, it is also present in some areas of the eastern basin and the African-Atlantic coast (Zibrowius et al. 1984, Chintiroglou et al. 1989).

Harvesting is the major source of disturbance in red coral populations (Santangelo et al. 1993, Santangelo \& Abbiati 2001), although large-scale mortalities have also been documented (Arnoux et al. 1992, Garrabou et al. 2001). Recreational diving seems to have a limited impact on populations but the potential risks of poaching and mechanical disturbance will increase in the near future with the predictable increase of diving (Garrabou \& Harmelin 2002).

According to Garrabou \& Harmelin (2002), red coral has a high survivorship, with $60 \%$ of colonies reaching 22 years of age. Mortality is higher in juveniles, but partial mortality of colonies is higher in old colonies (Garrabou \& Harmelin 2002). Age at first reproduction is, on average, between 7 and $10 \mathrm{yr}$, although the reproductive effort, i.e., the percentage of gravid polyps per colony, is higher in older colonies (Torrents et al. 2005). Male gonads develop within $1 \mathrm{yr}$, whereas the maturation of female gonads takes $2 \mathrm{yr}$ (Vighi 1972). Planulae emission seems to be related to water temperature and lasts from May-October, according to each geographical area (LacazeDuthiers 1864, Lo Bianco 1909, Cerruti 1921, Vighi 1972, Santangelo et al. 2003). There is indirect 


\section{MEDITERRANEAN CORALLIGENOUS ASSEMBLAGES}

evidence to suggest that the larval dispersal capability of red coral is reduced (Weinberg 1979, Abbiati et al. 1993), and it seems that genetic exchange between populations is also limited, promoting the presence of several discrete and distinct populations in the Mediterranean (Abbiati et al. 1993).

Recruitment, when studied in experimental panels, is usually high at the beginning, subsequently decreasing (Garrabou \& Harmelin 2002, Bramanti et al. 2005). However, differences in the results obtained by Garrabou \& Harmelin (2002) and Bramanti et al. (2005) suggest there is high population variability in recruitment and colonization rates.

Growth rates for red coral estimated by petrographic methods range from $1.57-0.91 \mathrm{~mm} \mathrm{yr}^{-1}$ for basal diameter (García-Rodríguez \& Massó 1986, Abbiati et al. 1992), but estimates decrease to $0.62 \mathrm{~mm} \mathrm{yr}^{-1}$ in mid-term (4 yr) observations (Cerrano et al. 1999, Bramanti et al. 2005) and to $0.24 \mathrm{~mm} \mathrm{yr}^{-1}$ in long-term (22 yr) studies (Garrabou \& Harmelin 2002). A new technique for aging red coral developed by Marschal et al. (2005) suggests mean growth rates of around $0.35 \mathrm{~mm} \mathrm{yr}^{-1}$, in close agreement with long-term observations. Growth rates in colony height have been estimated to be around $1.8 \mathrm{~mm} \mathrm{yr}^{-1}$ (Garrabou \& Harmelin 2002, Bramanti et al. 2005). The average branching rate for each colony is 3.4 branches in $22 \mathrm{yr}$ (Garrabou \& Harmelin 2002). Harvested populations show about two-fold lower values on average, and up to four-fold lower values in colony size compared with nonharvested populations. Garrabou \& Harmelin (2002) provide indisputable data on the longevity of colonies and the parsimonious population dynamics of C. rubrum. Current populations have shown a dramatic shift in their size structure, characterized by the absence of large colonies (Figure 22). Full recovery of shallow-water harvested populations may take several decades or even centuries (Garrabou \& Harmelin, 2002).

No sign of predation has been observed in monitored colonies of C. rubrum (Garrabou \& Harmelin 2002). In fact, predation appears to play a minor role in sessile, invertebrate-dominated communities as a whole (Garrabou et al. 2002).

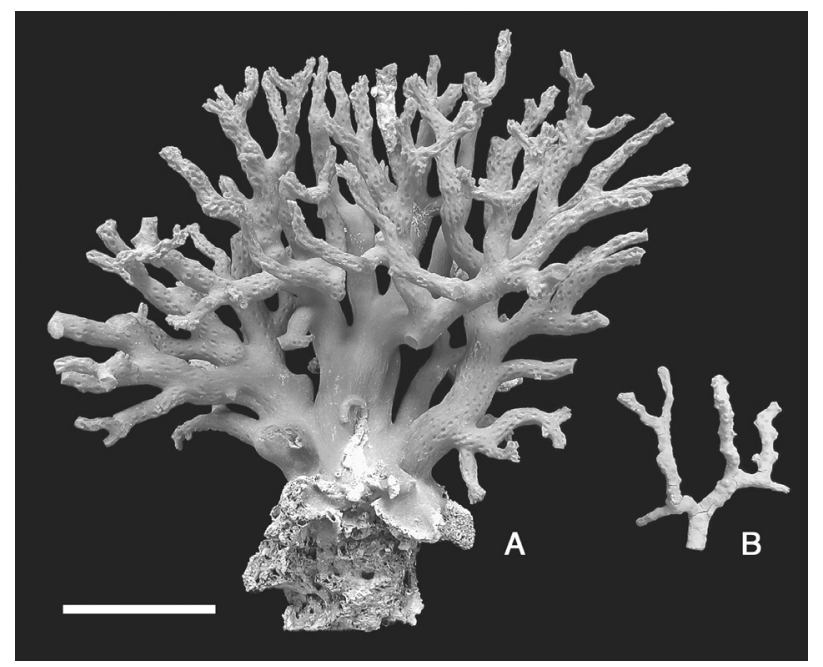

Figure 22 (See also Colour Figure 22 in the insert.) A red coral colony (age unknown) from a pristine site (Cap Creus, $35 \mathrm{~m}$ ) collected in 1962 (A), and a 28-year-old colony from an experimental panel (Riou Caramassaigne, $62 \mathrm{~m}$ ) (B). (Photo and data courtesy of J.G. Harmelin.) 


\section{ENRIC BALLESTEROS}

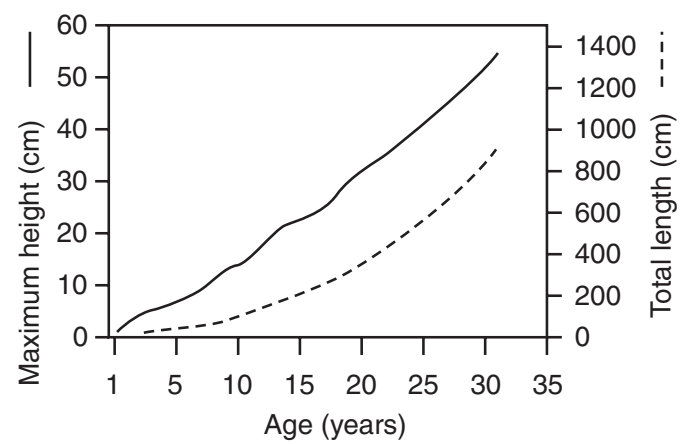

Figure 23 Predicted size of colonies using size-specific growth rates in the gorgonian Paramuricea clavata from coralligenous walls in the Medes Islands (NE Spain). Continuous line: maximum colony height; dashed line: total length. (From Coma et al. 1998b. With permission from Elsevier.)

\section{Gorgonia}

Growth of Paramuricea clavata has been monitored photographically over a 2-yr period (Coma et al. 1998b). Based on growth-rate data, the largest colonies in the population $(55 \mathrm{~cm})$ were around 31 years old (Figure 23). On average, net production for all colonies was $75 \%$ of gross production. Gross production was $4.4 \mathrm{~g}$ ash free dry weight (afdw) $\mathrm{m}^{-2} \mathrm{yr}^{-1}$, while the $\mathrm{P} / \mathrm{B}$ value was $0.11 \mathrm{yr}^{-1}$ and the turnover time was 9 yr (Coma et al. 1998a,b). Mistri \& Ceccherelli (1994), in a study of $P$. clavata in the Straits of Messina (Italy), estimated a production of $3 \mathrm{~g} \mathrm{afdw}^{-2} \mathrm{yr}^{-1}$, a $\mathrm{P} / \mathrm{B}$ value of $0.13 \mathrm{yr}^{-1}$ and a turnover rate of $7.5 \mathrm{yr}$. In Eunicella cavolinii, Weinbauer \& Velimirov (1995a,b) have estimated a production of 0.3-7.4 $\mathrm{g}$ afdw m $\mathrm{m}^{-2} \mathrm{yr}^{-1}$, a P/B around 0.24 and $0.32 \mathrm{yr}^{-1}$, and a turnover rate ranging from $3-4$ years.

Mean increase in maximum height for Paramuricea clavata ranges from 1.8-2.7 $\mathrm{cm} \mathrm{yr}^{-1}$ (Weinberg \& Weinberg 1979, Mistri \& Ceccherelli 1994, Coma et al. 1998a). Similar values have been obtained for Eunicella singularis (2.2 $\mathrm{cm} \mathrm{yr}^{-1}$; Weinberg \& Weinberg 1979). Growth is lower in E. cavolinii (0.85-1.14 $\mathrm{cm} \mathrm{yr}^{-1}$; Velimirov 1975, Weinbauer \& Velimirov 1995a).

Seasonality of growth in Paramuricea clavata requires long monitoring periods in order to be accurately detected, but available data suggest there is a high growth period in spring (Figure 24), this being consistent with the seasonal fluctuation in food sources (Coma et al. 1998b).

The minimum age at first reproduction in P. clavata has been estimated to be around 7-13 yr on average (Coma et al. 1995a). Fecundity levels increase with colony size. Oogenesis in P. clavata lasts for 13-18 months and culminates with the release of mature eggs in June-July; reproduction is synchronous each year and, as well as coinciding with increasing water temperature, it is correlated with the lunar cycle (Coma et al. 1995a). Spawned eggs adhere to the outer surfaces of female colonies through the action of a mucous coating. Embryogeny and final maturation takes place among the polyps. On leaving the surface of the colonies, larvae immediately settle on the surrounding substratum. Maintenance of the population is based on sexual reproduction (Coma et al. 1995b).

Zooplankton (nauplii, copepod eggs, other invertebrate eggs, calanoid copepods) accounts for an important share of the diet. Peak prey capture levels are recorded in spring and at the end of autumn; they fall off substantially in summer, when the proportion of colonies with contracted polyps is very high. The prey capture rate extrapolated to an annual cycle suggests that gorgonians play an important role in the flow of energy from plankton to the benthos; estimates from P. clavata populations situated in the Medes Islands indicate that this species can remove the equivalent of between 12 and $85 \mathrm{mg} \mathrm{C} \mathrm{m}^{-2}$ day $^{-1}$ from the zooplankton (Coma et al. 1994). 


\section{MEDITERRANEAN CORALLIGENOUS ASSEMBLAGES}

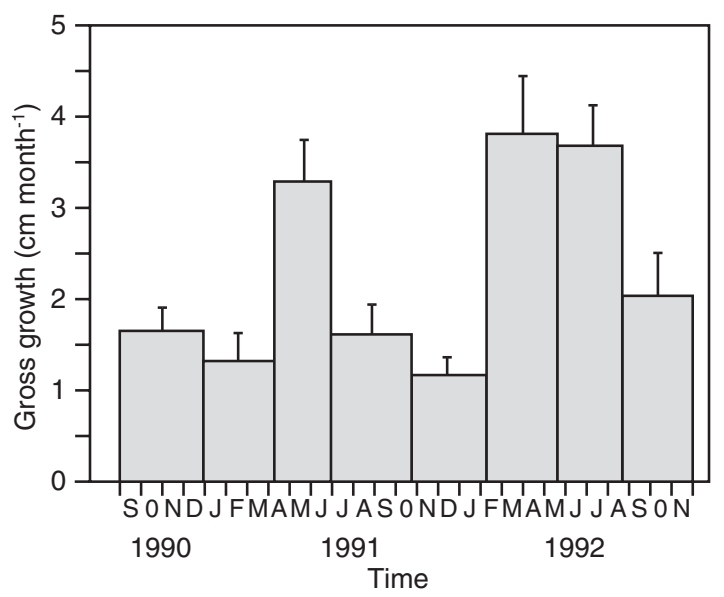

Figure 24 Available data on growth of the gorgonian Paramuricea clavata suggests a period of high growth during spring. Error bars show standard error. (From Coma et al. 1998b. With permission from Elsevier.)

However, P. clavata has a broad and heterogenous diet that ranges from nano-eukaryotes $(3.8 \mu \mathrm{m})$ to copepods $(700 \mu \mathrm{m})$, and includes prey as diverse as ciliates, dinoflagellates, diatoms and suspended detrital organic matter (Ribes et al. 1999c). Carbon of detrital origin accounts for roughly $48 \%$ of the total ingested carbon and shows a marked seasonal pattern, in which winter and spring are the seasons with the highest ingestion rates. The amount of carbon removed from the surrounding water is equivalent to $2.7 \mathrm{mg} \mathrm{C} \mathrm{m}^{-2}$ day $^{-1}$ from the living POC (including nanoeukaryotes, diatoms, ciliates and dinoflagellates) and $28.7 \mathrm{mg} \mathrm{C} \mathrm{m}^{-2}$ day-1 from the detrital POC. No significant capture of dissolved organic matter or picoplankton has been observed. Ribes et al. (1999c) give an estimate of the partitioning of food sources that cover the energy needs of $P$. clavata, assuming data on ingestion rates observed in incubation chambers corrected by the effect of flow speed obtained from the literature. According to these authors, zooplankton and detrital POC make a similar contribution (about 48\% each), with the living POC accounting for the remaining 4\%, a figure that can probably be extrapolated to other gorgonians.

\section{Alcyonaria}

The alcyonarian Alcyonium acaule has a very slow growth, which is almost undetectable over a 2 -yr period (Garrabou 1999). Recruitment is very low and occurs in autumn, this being the only method of population maintenance because there is no asexual reproduction. Mortality rates average $12.7 \% \mathrm{yr}^{-1}$, with much higher mortalities in small colonies. Contracted colonies are much more frequent in summer than in any other season (up to 80\%) (Garrabou 1999, Rossi 2001). Colonies of $A$. acaule are usually aggregated due to the retention of eggs by the mucous strings, implying a short-range dispersal for larvae and settlement near the parental colonies (Garrabou 1999).

\section{Zoantharia}

Growth and occupation of space of Parazoanthus axinellae in the coralligenous communities of the Medes Islands (northwestern Mediterranean) have been studied by Garrabou (1999). It has moderate growth dynamics (relative growth rate of 0.11 month $^{-1}$ and a shrinkage rate of 0.09 month $^{-1}$ ) with nonsignificant differences over time, although growth rates peak during the summer to autumn period. Fission is common, 29\% of monitored colonies undergoing at least one fission 


\section{ENRIC BALLESTEROS}

in 2 yr. Fusion was less frequent, with only $8 \%$ of colonies undergoing fusion in 2 yr. Mortality rates average $9 \% \mathrm{yr}^{-1}$. The occupation of space in P. axinellae seems to be based on spreading over the substrata at moderate rates, either by somatic growth or by fission. Most of the colonies $(60 \%)$ were contracted in summer and mid autumn (Garrabou 1999, Rossi 2001).

\section{Tunicata}

Colonies of Cystodites dellechiajei, a very common ascidian in coralligenous communities (Ramos 1991), exhibited no or only restricted growth over a 2-yr period in a vertical wall at a depth of 10-12 $\mathrm{m}$ in the northwestern Mediterranean (Turon \& Becerro 1992), although one of eleven colonies was able to grow actively. According to the authors' observations, only the individuals present in the most shaded microenvironments displayed active growth. Gonads were present in the population for most of the year. This species shows a high relative biomass per unit area, low growth rates, high survival values (Turon \& Becerro 1992) and the presence of chemical defences (Uriz et al. 1991), which would seem to indicate a very conservative life strategy.

Two solitary ascidian species common in coralligenous assemblages spawn in late summer and early autumn. Gamete release occurred after the period of highest temperature (September-October) in Halocynthia papillosa, while for Microcosmus sabatieri it occurred in October-November (Becerro \& Turon 1992). In order to explain the surprising fact of spawning after summer, a period of temperature and food limitation, Ribes et al. (1998) studied the natural diet and prey capture of the ascidian Halocynthia papillosa across an annual cycle. The natural diet included detrital organic matter, bacteria, Prochlorococcus and Synechococcus, protozoans and phytoplankton, with a mean size ranging from $<1 \mu \mathrm{m}-70 \mu \mathrm{m}$. One specimen of Halocynthia papillosa weighing $0.25 \mathrm{~g}$ afdw was estimated to ingest an annual mean of $1305 \mu \mathrm{g} \mathrm{C} \mathrm{g} \mathrm{afdw}{ }^{-1} \mathrm{~h}^{-1}$. Carbon from detrital origin accounted for $92 \%$ of the total ingested carbon, while live carbon accounted for only $8 \%$. Ingestion rates showed a marked seasonal pattern, with the highest ingestion of detrital particles in spring and the highest values of ingestion of live particles in summer and autumn. Ribes et al. (1998) hypothesise that live particles are of more significance in the species' diet than are particles of detrital origin, because the seasonal variation of ingested nitrogen from live particles explained $91 \%$ of the gonadal development variance for the year. Thus, living sestonic organisms, rather than detrital carbon, may be an essential source of nitrogen and other nutrients necessary for growth and reproduction in $H$. papillosa.

\section{Disturbances}

\section{Large-scale events}

Several episodes of suspension feeder mortality have been detected in the northwestern Mediterranean (Rivoire 1991, Bavestrello et al. 1994, Cerrano et al. 2000, Perez et al. 2000, Garrabou et al. 2001). Here the existing data on the last large-scale mortality of suspension feeders that affected shallow water assemblages (10-40 m depth) eastwards from Marseilles and in some other areas of the central-western Mediterranean (Minorca; Ballesteros, unpublished data) is reported (Figure 25A,B).

Owing to climatic and hydrographic anomalies in the Ligurian Sea, the characteristic summer conditions of reduced resources, high water column stability and high temperatures (normally during July and August) lasted much longer than usual in the summer of 1999. This coincided with a mass mortality of benthic suspension feeders over several hundred kilometres, affecting coralligenous communities situated at a depth of $<40 \mathrm{~m}$ (Figure 26), where the temperature anomaly lasted for over a month (Perez et al. 2000, Romano et al. 2000). The accumulated density decrease in 


\section{MEDITERRANEAN CORALLIGENOUS ASSEMBLAGES}
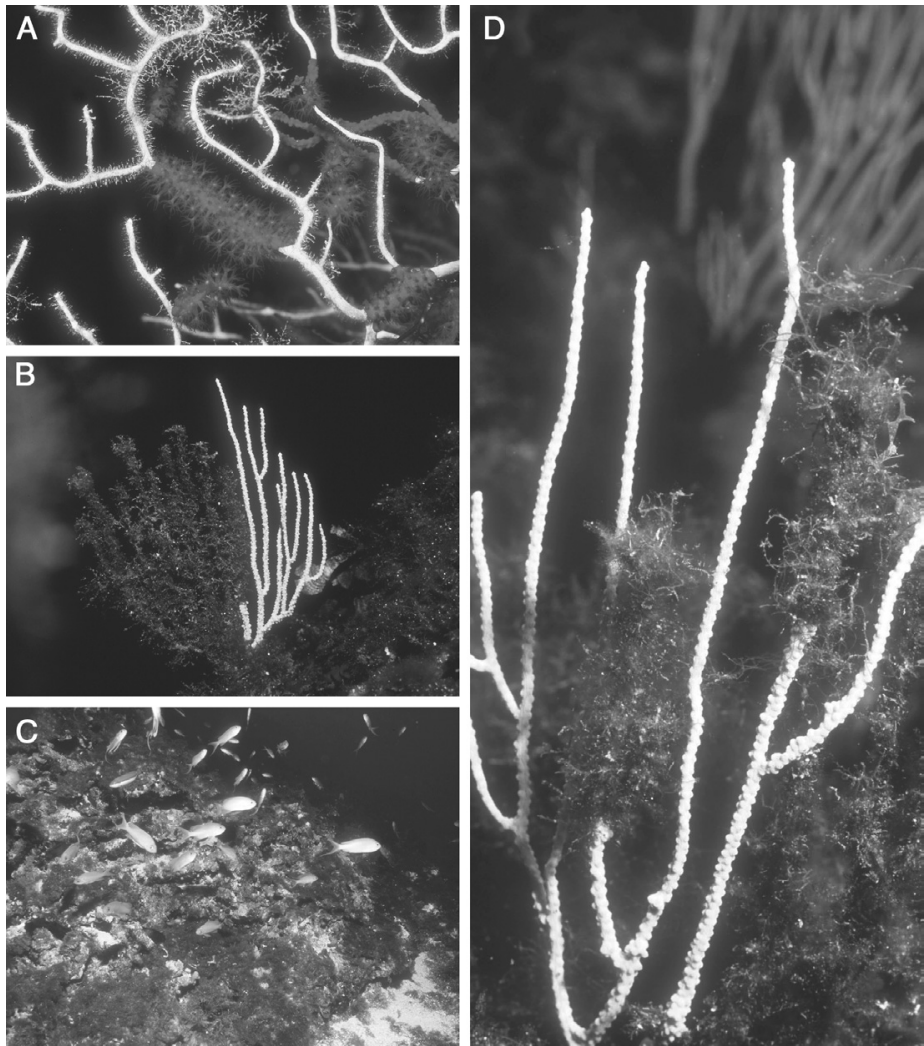

Figure 25 (See also Colour Figure 25 in the insert.) Disturbances in coralligenous communities. (A) Mortality affecting the gorgonian Paramuricea clavata (Port-Cros, France, autumn 1999); (B) Dense carpets of alien alga Womersleyella setacea cover coralligenous assemblages; the gorgonian Eunicella singularis is also affected by previous partial mortality that occurred in summer 1999 (Minorca, Balearic Islands, summer 2000); (C) Filamentous alien alga Womersleyella setacea invades coralligenous rims dominated by Mesophyllum alternans in Cabrera (Balearic Islands, autumn 1999); (D) Partial mortality and overgrowth by filamentous algae affecting gorgonian Eunicella singularis (Minorca, Balearic Islands, summer 2000). (Photos by the author.)

Paramuricea clavata colonies $4 \mathrm{yr}$ after the mass mortality accounts for around half the initial population at the Port-Cros National Park (France) (Linares et al. 2005). Red coral populations thriving above a depth of $30 \mathrm{~m}$ were also affected (Garrabou et al. 2001). This large-scale mortality, together with other small-scale mass mortalities (Cerrano et al. 2000) recorded during the past decade in the Mediterranean, may be related to seawater temperature increase and global warming. Some suspension feeders might be able to withstand the normal duration of adverse summer conditions but not an anomalous prolongation of these conditions (Coma et al. 2000; Coma \& Ribes 2003), resulting from an energy shortage of suspension feeders related to low food availability in summer.

If mass mortalities are indeed related to the global warming trend, such events might occur again and become more frequent, which would cause profound changes in the specific composition and structure of coralligenous communities. In fact, $P$. clavata, the suspension feeder most drastically affected in the summer 1999 mortality (Perez et al. 2000), is completely absent above a depth 


\section{ENRIC BALLESTEROS}

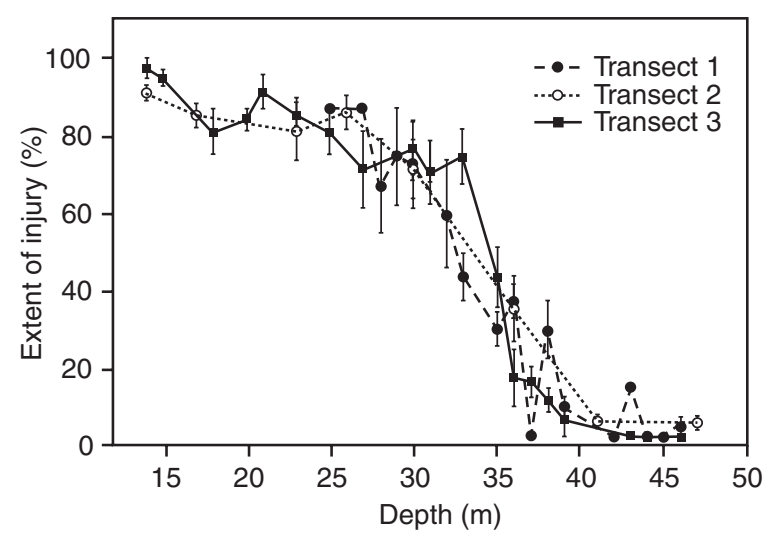

Figure 26 Extent of injury (mean \pm SE) of Paramuricea clavata colonies along three depth transects in the summer 1999 mortality at La Gabinière (Port-Cros, France, autumn 1999). (Unpublished data, courtesy of C. Linares, R. Coma, D. Diaz, M. Zabala, B. Hereu and L. Dantart.)

of $40 \mathrm{~m}$ in the warm central Mediterranean waters of the Balearic Islands (Ballesteros, unpublished data), and this may be related to the longer duration of summer conditions in this area. However, the ultimate cause of these mortalities remains unclear, because the temperature anomaly can only have caused physiological stress which, in turn, has triggered the development of some pathogenic agent that would otherwise have remained nonvirulent.

\section{Degradation by waste water}

Hong (1980) studied the effects of waste water along three stations situated in a gradient of multisource pollution in the Gulf of Fos (Marseilles), and in an unpolluted reference zone. Biodiversity decreased from the reference station ( 310 species) to the most polluted zone (214 species), and mainly affected bryozoans, crustaceans and echinoderms; molluscs and polychaetes were largely unaffected. The number of individuals also decreased with increased pollution, as did the biomass of sponges and bryozoans, and the diversity of invertebrates. However, the density of sipunculids as well as the relative abundance of species with a wide ecological distribution was enhanced by pollution (Hong 1980, 1983).

The abundances of the species responsible for accretion and those living in the coralligenous community decrease with the pollution gradient, both in terms of number and density of individuals. There are few data concerning the impact of various pollutants on the growth of coralline algae (Littler 1976), although it is known that orthophosphate ions inhibit calcification (Simkiss 1964). However, Hong (1980) observed that with increased pollution large thalli of Mesophyllum alternans are replaced by Peyssonneliaceae, which have a much lower building capacity (Sartoretto 1996). Moreover, the species that act as bioeroders are more abundant in the polluted areas (Hong 1980). Thus, all the available evidence suggests that pollution accelerates the destruction of coralligenous assemblages and inhibits building activity.

Cormaci et al. (1985) studied the deep water phytobenthic communities developing over coralligenous concretions in the Gulf of Augusta, a site that is heavily polluted by both urban and industrial wastewater. Water turbidity seems to be the main factor causing degradation and homogenisation of the phytobenthos. There is a slight decrease in the number of species ( 26 algal species sample ${ }^{-1}$ ) when compared with similar sites and depths of unpolluted areas (30-38 algal species sample ${ }^{-1}$ ) (Furnari et al. 1977, Battiato et al. 1979). 


\section{MEDITERRANEAN CORALLIGENOUS ASSEMBLAGES}

\section{Degradation by fishing}

Trawling is probably the most destructive fishing method and is causing degradation of large areas of coralligenous concretions (Boudouresque et al. 1990). Trawling not only causes direct physical damage by breaking down the coralligenous structure and rolling the coralligenous blocks but also negatively affects photosynthetic production of encrusting and erect algae by increasing turbidity and sedimentation rates when applied to adjacent sedimentary bottoms (Palanques et al. 2001).

Special trawling to collect precious red coral with what is known as the 'Italian Bar' or 'St. Andrew Cross' is highly destructive. Ortiz et al. (1986) reported the capture of up to $50 \mathrm{~kg}$ of benthic fauna (mainly gorgonians) in order to collect $15 \mathrm{~kg}$ of living red coral in the Alboran Sea. The abovementioned device is so effective at destroying the sea bed that it has also been used for scientific studies of fauna associated with red coral (Templado et al. 1986, Maldonado 1992).

Both traditional and recreational fishing also have an effect on coralligenous communities, although they mainly affect the target species. Fishing leads to a significant decrease in mean specific number of fish species, producing changes in the composition of the community (Bell 1983, Garcia-Rubies \& Zabala 1990). This effect is due not only to the nearly total absence of some fishes, demonstrated in two species (Epinephelus marginatus and Sciaena umbra) that are extremely vulnerable to spear-fishing, but also to the notable scarcity of other species (GarciaRubies 1999). However, depth acts as a protective factor by limiting the effects of fishing, given the inherent difficulty in locating from the surface the coralligenous bottoms that are isolated from the coast (Garcia-Rubies 1999). No cascading effects through overfishing have so far been detected in coralligenous communities, as they have been in shallow rocky bottoms (Sala et al. 1998), although they may well exist because both densities and sizes of fishes and lobsters have been greatly modified over the last $100 \mathrm{yr}$. Nevertheless, populations of groupers and other vulnerable fishes rapidly recover after fishing is prohibited (Harmelin 1991, Coll et al. 1999, Harmelin \& Robert 2001) and readily exhibit normal socio-behavioural patterns and reproductive success (Zabala et al. 1997a,b).

\section{Degradation by the activity of divers}

The coralligenous community is one of the most popular sites for recreational diving in the Mediterranean (Boudouresque 2004b) due to its great variety of life and great visual appeal (Harmelin 1993). Some studies have detected the direct impact of divers on the largest invertebrates of the coralligenous community. Sala et al. (1996) found that the large and fragile calcareous bryozoan Pentapora fascialis was present at all levels of exposure (from overhangs to epibiotic) in locations where diving was not allowed, whereas colonies were largely restricted to cryptic positions at diving locations in the Medes Islands marine reserve. Density, colony diameter and colony height were also significantly lower at frequented than at unfrequented sites. Densities of colonies of the bryozoan P. fascialis showed a significant decrease (50\% in $1 \mathrm{yr})$ after a diving site was opened in the marine protected area of the Medes Islands (Garrabou et al. 1998). The impact was greater on boulders covered by coralligenous concretions than on vertical walls, probably as a result of the protection provided by the dense canopy of the gorgonian Paramuricea clavata. However, these high levels of recreational scuba diving (e.g., $>1000$ visits $s^{2} \mathrm{e}^{-1} \mathrm{yr}^{-1}$ ) also appear to be greatly modifying the natural demographic parameters of $P$. clavata in the Medes Islands marine reserve and adjacent sites by means of a three-fold increase in adult mortality (Coma et al. 2004). This increase in adult mortality is due to toppling by divers, because annual mortality induced by overgrowth is almost similar in dived and undived sites, whereas annual mortality by toppling in high visitation areas ranges from 4.9-6.9\% (1.5\% in rarely visited sites). Nonintentional breaking of P. clavata has also been reported by Harmelin \& Marinopoulos (1994) from the coralligenous 


\section{ENRIC BALLESTEROS}

communities in Port-Cros National Park (France). Anchoring of boats seems also to have a negative impact on coralligenous assemblages, although there are no studies where this has been adequately assessed.

Garrabou et al. (1998) conclude that abrasion by divers may affect other organisms of the coralligenous community because it contains many sessile, long-lived organisms with fragile skeletons and slow growth rates that make them very prone to disturbance by toppling. They suggest that diving might lead the coralligenous community to be dominated by erosion-resistant species, such as encrusting and massive organisms, rather than erect, articulate and foliose species. Therefore, human activities may affect the coralligenous community as a whole. Unfortunately, the paucity of data on turnover rates for most organisms thriving on coralligenous assemblages does not allow a quantitative estimate to be made of diver carrying capacity (Sala et al. 1996).

\section{Invasive species}

Some species introduced into the Mediterranean have become invasive (Boudouresque \& Ribera 1994, Boudouresque \& Verlaque 2002) and a number of them can thrive in, or are more or less adapted to, the coralligenous habitat. Currently, only introduced algal species are threatening the coralligenous community and then only in some areas of the Mediterranean.

Probably the most dangerous alien species for the coralligenous community is the small red alga Womersleyella (Polysiphonia) setacea, which is currently distributed along most of the Mediterranean basin (see Athanasiadis 1997). This species grows abundantly in coralligenous (and other sublittoral) communities (Figure 25C,D), forming a dense carpet, 1-2 cm thick, over the encrusting corallines that constitute the concretion (Mesophyllum alternans, Lithophyllum cabiochae, and others) (Ballesteros 2004). The carpet of Womersleyella setacea undoubtedly decreases light availability to the encrusting corallines (avoiding or reducing photosynthesis and growth of these algae), increases sediment trapping (Airoldi et al. 1995), excludes other macroalgae by overgrowth and pre-emption (Piazzi et al. 2002), and inhibits recruitment of corallines and other algal and animal species inhabiting the coralligenous community (Ballesteros et al. 1998). This alga is also very successful at establishing itself and persisting from year to year (Airoldi 1998). It therefore may cause enormous damage to the entire coralligenous community. Indeed, the species richness found in sites invaded by W. setacea is lower than that observed in noncolonised sites (Piazzi et al. 2002).

Another alien turf alga that is able to grow in deep waters is Acrothamnion preissii which, nevertheless, has been mainly reported from maërl beds (Ferrer et al. 1994) and the rhizomes of the seagrass Posidonia oceanica (Piazzi et al. 1996). Although present in the coralligenous community of the Balearic Islands (Ballesteros, personal observation), it is never dominant in this environment and always grows together with Womersleyella setacea.

Caulerpa taxifolia is another species that can threaten the coralligenous community. Although mainly found in relatively shallow waters (Meinesz \& Hesse 1991), it has been recorded down to a depth of $99 \mathrm{~m}$ (Belsher \& Meinesz 1995) and in some areas, such as Cap Martin (France), it has totally invaded the coralligenous community (Meinesz 1999). C. racemosa var. cylindracea, another invasive species that is quickly spreading in the Mediterranean (Piazzi et al. 2005), is also able to grow in deep waters where coralligenous assemblages develop (down to a depth of $55 \mathrm{~m}$ in the Balearic Islands; Ballesteros 2004) but no information about its impact on the coralligenous community is available.

Two other species that have been reported to act as invaders in the Mediterranean are Asparagopsis taxiformis (Ballesteros \& Rodríguez-Prieto 1996) and Lophocladia lallemandii (Patzner 1998). These two species are becoming increasingly abundant both in shallow bottoms and deep

waters around the Balearic Islands. They have been found to a depth of $65 \mathrm{~m}$ on coralligenous bottoms with or without Womersleyella setacea (Ballesteros, personal observation). 


\section{MEDITERRANEAN CORALLIGENOUS ASSEMBLAGES}

\section{Conclusions regarding current knowledge of coralligenous communities}

The coralligenous habitat, as described here, is a typical Mediterranean underwater landscape that basically comprises coralline algae growing in dim light conditions and in relatively calm waters. Although it usually develops in the circalittoral zone it can also thrive in the lower infralittoral zone if irradiance levels are low enough to allow the growth of the encrusting corallines.

Most of the available data come from studies conducted in the western Mediterranean. Almost nothing is known about eastern Mediterranean coralligenous habitats, and this may be related to both the greater depth where the coralligenous habitat develops in this area (usually beyond the normal limit of scientific scuba diving) and to the lack of traditional marine research institutes.

The main distribution of coralligenous communities has been well documented on a large scale: it is common all around the Mediterranean coasts, with the possible exception of those of Lebanon and Israel.

Knowledge about environmental factors is rather poor because the coralligenous habitat is a highly heterogenous system and environmental variables can differ greatly on both a geographical and a microscale. However, even though more data are necessary, basic knowledge of light (irradiance), temperatures, nutrient concentrations and hydrodynamism is available. Irradiance seems to be the most critical factor for the development of coralligenous frameworks. Available data suggest that light levels must range between $1.3 \mathrm{MJ} \mathrm{m}^{-2} \mathrm{yr}^{-1}$ and $50-100 \mathrm{MJ} \mathrm{m}^{-2} \mathrm{yr}^{-1}$, that is, between $0.05 \%$ and $3 \%$ of the surface irradiance.

Two main morphologies can be distinguished: banks, which are built over more or less horizontal substrata, and rims, which develop in the outer parts of marine caves and vertical cliffs.

The coralligenous habitat includes several assemblages due to its great heterogeneity. Algal assemblages develop in open waters and are dominated by several species of encrusting red algae. Mesophyllum alternans dominates in relatively shallow waters while Lithophyllum frondosum, L. cabiochae and Neogoniolithon mamillosum are more abundant in deep waters. Two main algal assemblages have been distinguished. Shallow-water assemblages are rich in species of green algae, while deep-water assemblages have a poorer algal flora, with some encrusting and foliaceous red algae. Animal assemblages differ greatly among sites and geographical areas. In open areas, mixed with algae, cnidarians dominate the assemblage (mainly gorgonians) in relatively eutrophic areas, while in more oligotrophic waters sponges and bryozoans dominate. On overhangs and in large cavities the communities of suspension feeders are dominated by anthozoans, sponges and bryozoans. Some research has studied algal and animal builders, as well as bioeroders. However, biomass data for the species composing the assemblages are very scarce.

A considerable amount of research has been done on the biodiversity of coralligenous frameworks. Much more data could probably be gathered by taking into account floristic and faunistic studies, as well as monographs from the different groups that contain comments on the ecological distribution of species. A first estimate on the number of species thriving in coralligenous communities is around 1666 (315 algae, 1241 invertebrates and 110 fishes). Studies dealing with the coralligenous communities of certain areas give the number of species as ranging between 500 and 700 species of marine invertebrates. Also important is the very high density of vagile fauna that inhabit coralligenous outcrops, which can reach $>3$ invertebrates $\mathrm{g}^{-1}$ of coralligenous concretion and, for example, a density of $>1$ polychaete worm $\mathrm{cm}^{-2}$.

Some endangered Mediterranean species live in the coralligenous habitat, although none is exclusive to this environment.

As its diversity is so great, the coralligenous habitat reveals an intense connectivity among its inhabitants. Space competition is strong because the space is completely saturated by organisms, and epibiosis is extremely frequent. Alellochemicals must play an important role in space competition 


\section{ENRIC BALLESTEROS}

because coralligenous communities exhibit a very high percentage of chemically active species. Trophic relationships are also strong in coralligenous communities, particularly among vagile species because most of the sessile invertebrates have skeletons that deter feeding. Several examples of mutualism, commensalism and parasitism have been reported.

Growth of coralligenous accretions, carbonate production, and bioerosion and sedimentation rates have merited very few studies, although those published have presented very valuable data. They indicate (1) very low accumulation rates which are related to water depth and light availability; (2) the important source of carbonate for the continental shelf represented by coralligenous buildups;

(3) relatively low bioerosion rates, at least in deep waters where algal growth is the lowest; and

(4) relatively high sedimentation rates. Accretion rates of up to $0.83 \mathrm{~mm} \mathrm{yr}^{-1}$, carbonate production (vegetal and animal) of up to $1000 \mathrm{~g} \mathrm{CaCO}_{3} \mathrm{~m}^{-2} \mathrm{yr}^{-1}$, and values for bioerosion of up to $220 \mathrm{~g}$ $\mathrm{CaCO}_{3} \mathrm{~m}^{-2}$ year-1 have been reported. These values are always higher in shallow than in deep waters.

Large animals and plants of coralligenous assemblages are highly persistent, and show low to nil seasonality in terms of space occupation. Most of the area covered by a coralligenous community remains unchanged after, for example, 2 yr of monitoring. However, growth pulses have been detected in some organisms such as the green alga Halimeda tuna or its epiphytic hydrozoans. Vagile invertebrates and the fish fauna also show a degree of seasonality, mainly due to recruitment pulses and inactivity in winter. Several suspension feeders also exhibit some physiological seasonality, with decreased activity in summer, probably related to the low food availability and high temperatures that occur during this season.

Some species inhabiting coralligenous assemblages (algae Mesophyllum alternans, Lithophyllum frondosum and Halimeda tuna; sponges Hemimycale columella, Crambe crambe, Chondrosia reniformis, Dysidea avara and Oscarella lobularis; hydrozoans Orthopyxis crenata, Halecium petrosum and $H$. pusillum; anthozoans Paramuricea clavata, Eunicella cavolinii, E. singularis, Corallium rubrum, Alcyonium acaule, Parazoanthus axinellae; tunicates Halocynthia papillosa, Cystodytes dellechiajei and Microcosmus sabatieri) have been carefully studied in order to determine one or several of the following features: growth rates, population dynamics, age, carbonate production, natural diets, prey capture, reproduction, spawning and recruitment patterns.

Five main causes of disturbance that affect coralligenous assemblages have been distinguished:

1. Large-scale events, involving mass mortalities of suspension feeders, seem to be related to summer high water column stability and high temperatures but their ultimate causes remain unclear. It has been suggested that they are related to the current global warming trend.

2. Waste waters profoundly affect the structure of coralligenous communities by inhibiting coralline algal growth, increasing bioerosion rates, decreasing species richness and densities of the largest individuals of the epifauna, eliminating some taxonomical groups (e.g., most echinoderms, bryozoans and crustaceans), and increasing the abundance of highly tolerant species.

3. Fishing is another cause of coralligenous degradation. Trawling is especially destructive, for not only does it physically destroy the coralligenous structure but it also increases turbidity and sedimentation rates, which negatively affects algal growth and suspension feeding. Traditional, as well as recreational, fishing mainly affect target species, although most of them rapidly recover after fishing prohibition or after implementation of scientifically guided fisheries management. However, this is not the case for the long-lived and slow-growing red coral, whose full recovery from harvesting has been estimated to take several decades or even centuries. 


\section{MEDITERRANEAN CORALLIGENOUS ASSEMBLAGES}

4. Diver activity is another cause of recent degradation of coralligenous assemblages, although this kind of disturbance only affects, at the moment, very few areas situated at the most popular sites for recreational diving.

5. Finally, invasive alien species are another cause of concern because their numbers are increasing throughout the Mediterranean. Especially dangerous for the coralligenous communities is the red turf alga Womersleyella setacea, which forms a dense carpet over encrusting corallines, thus inhibiting photosynthesis and growth of the main coralligenous builders.

\section{Actions}

\section{Gaps in scientific knowledge}

In terms of the current state of scientific knowledge of the coralligenous habitat it is easy to detect several gaps that make it rather difficult to make recommendations for protecting coralligenous assemblages:

1. There is a complete lack of knowledge of the distribution of coralligenous substrata in the Mediterranean, with the exception of some extremely limited areas situated mainly in marine parks or reserves. As a minimum, approximate cartography and quantification of these bottoms is required.

2. It is highly recommended that a list of all the organisms that have been found living in coralligenous communities be drawn up, in order to have a precise idea of the amount of biodiversity contained in this environment.

3. Almost nothing is known about the coralligenous concretions from the eastern Mediterranean. Special efforts must be made to investigate the description and functioning of coralligenous communities in this area.

4. Further studies dealing with the processes involved in the buildup and erosion of coralligenous assemblages must be conducted because almost all the existing information comes from one or two localities situated in the northwestern Mediterranean.

5. An understanding of the functioning of the dominant and keystone species is essential in order to implement an adequate management strategy for the coralligenous habitat.

6. The effect of disturbances in coralligenous assemblages is poorly understood, and there are no data at all on the capacity of this environment to recover (with the exception of fish stocks after fishing prohibition). The following issues would appear to be particularly important:

a. Indirect impact of trawling

b. Impact of waste-water dumping

c. Effects of alien species invasion

d. Causes of recent large-scale mortality events

\section{Recommendations for protecting coralligenous communities}

In the light of current knowledge, there are a number of recommendations that can be made in order to conserve (or even improve) coralligenous environments. Most of these recommendations concern not only the coralligenous habitat but most of the coastal benthic habitats because wastewater dumping, trawling and overfishing, and invasion by alien species are problems that affect the whole of the coastal area. Measures to reduce these impacts may improve the overall quality 


\section{ENRIC BALLESTEROS}

of the marine coastal environment. Specific measures aimed at protecting the coralligenous environment might include the following:

1. Waste-water dumping should be banned over coralligenous bottoms, and in their vicinity.

2. Trawling must be completely prohibited in areas with coralligenous outcrops and their vicinity, the aim being to avoid not only the physical damage caused by trawling over coralligenous assemblages but also the indirect effects due to increased turbidity and silting.

3. Any other anthropogenic activity involving an increase in water turbidity and/or sediment removal (e.g., coastline modification, beach regeneration) should be avoided in the vicinity of coralligenous outcrops.

4. Correct management of traditional and recreational fisheries must be implemented in order to prevent stock depletion of target fish and crustaceans.

5. The impact of diving must be compatible with the normal functioning and conservation of the coralligenous environment.

6. The enactment of suitable legislation concerning the introduction of alien species is urgently needed.

\section{Acknowledgements}

This review was funded by the GEF Strategic Action Plan for the Conservation of Biological Diversity (SAP BIO) project, supported by the United Nations Environment Programme - Mediterranean Action Plan (UNEP-MAP) under the responsibility of the Regional Activity Centre for Specially Protected Areas (RAC/SPA). I am indebted to Drs Joaquim Garrabou, Rafel Coma, Antoni Garcia-Rubies, Daniel Martin, Enrique Macpherson, María Jesús Uriz, Xavier Turon, Mikel Zabala and Jordi Camp for providing ecological and taxonomical advice and bibliography. Jordi Corbera and Mikel Zabala are kindly acknowledged for providing the artwork. I am also grateful to Dr. Marc Verlaque for his advice on coralline algae nomenclature, and to Dr. Jean Georges Harmelin for providing the picture and data for Figure 22.

\section{References}

Abbiati, M., Buffoni, G., Caforio, G., Di Cola, G. \& Santangelo, G. 1992. Harvesting, predation and competition effects on a red coral population. Netherlands Journal of Sea Research 30, 219-228.

Abbiati, M., Santangelo, G. \& Novelli, S. 1993. Genetic variation within and between two Thyrrenian populations of the Mediterranean alcyonarian Corallium rubrum. Marine Ecology Progress Series $\mathbf{9 5}$, 245-250.

Acunto, S., Balata, D. \& Cinelli, F. 2001. Variabilità spaziale del coralligeno e considerazione sul metodo di campionamento. Biologia Marina Mediterranea 8, 191-200.

Adey, W.H. 1978. Coral reef morphogenesis: a multidimensional model. Science 202, 831-837.

Adey, W.H. 1998. Coral reefs: algal structured and mediated ecosystems in shallow, turbulent, alkaline waters. Journal of Phycology 34, 393-406.

Adey, W.H. \& McIntyre, I.G. 1973. Crustose coralline algae: a re-evaluation in the geological sciences. Geological Society of America Bulletin 84, 883-904.

Adey, W.H. \& Vassar, J.M. 1975. Colonization, succession and growth rates of tropical crustose coralline algae (Rhodophyta, Cryptonemiales). Phycologia 14, 55-69.

Airoldi, L. 1998. Roles of disturbance, sediment stress, and substratum retention on spatial dominance in algal turf. Ecology 79, 2759-2770. 


\section{MEDITERRANEAN CORALLIGENOUS ASSEMBLAGES}

Airoldi, L., Rindi, F. \& Cinelli, F. 1995. Structure, seasonal dynamics and reproductive phenology of a filamentous turf assemblage on a sediment influenced, rocky subtidal shore. Botanica Marina 38, 227-237.

Arnoux, A., Harmelin, J.G., Monod, J.L., Romaña, L.A. \& Zibrowius, H. 1992. Altérations des peuplements benthiques de roches profondes en Méditerranée nord-occidentale: quelques aspects biologiques et molysmologiques. Comptes Rendus de l'Académie des Sciences de Paris Series III 314, 219-225.

Athanasiadis, A. 1987. A Survey of the Seaweeds of the Aegean Sea with Taxonomic Studies on Species of the Tribe Antithamniae (Rhodophyta). Kungälv: Göterna.

Athanasiadis, A. 1997. North Aegean marine algae. IV. Womersleyella setacea (Hollenberg) R.E. Norris (Rhodophyta, Ceramiales). Botanica Marina 40, 473-476.

Athanasiadis, A. 1999a. The taxonomic status of Lithophyllum stictaeforme (Rhodophyta, Corallinales) and its generic position in light of phylogenetic considerations. Nordic Journal of Botany 19, 735-745.

Athanasiadis, A. 1999b. Mesophyllum macedonis, nov. sp. (Rhodophyta, Corallinales), a putative Tethyan relic in the North Aegean Sea. European Journal of Phycology 34, 239-252.

Augier, H. \& Boudouresque, C.F. 1975. Dix ans de recherches dans la zone marine du Parc National de PortCros (France). Troisième partie. Annales de la Societé des Sciences Naturelles et d'Archéologie de Toulon et du Var 27, 131-170.

Augier, H., Boudouresque, C.F. \& Laborel, J. 1971. Végétation marine de l'île de Port-Cros (Parc National). VII. - Les peuplements sciaphiles profonds sur substrat dur. Bulletin du Muséum d'Histoire Naturelle de Marseille 20, 149-168.

Bacci, G. 1947. Ricerche sulle zoocenosi bentoniche del Golfo di Napoli, I. La secca di Benda Palumno. Pubblicazioni della Stazione Zoologica di Napoli 20, 158-178.

Bacescu, M. 1971. Les spongiaires: un des plus intéressants biotopes benthiques marins. Rapports et ProcèsVerbaux des Réunions de la Comission Internationale pour l'Exploration Scientifique de la Mer Méditerranée 20, 239-241.

Ballesteros, E. 1990. Structure and dynamics of the community of Cystoseira zosteroides (Turner) C. Agardh (Fucales, Phaeophyceae) in the northwestern Mediterranean. Scientia Marina 54, 217-229.

Ballesteros, E. 1991a. Structure and dynamics of north-western Mediterranean marine communities: a conceptual model. Oecologia Aquatica 10, 223-242.

Ballesteros, E. 1991b. Structure of a deep-water community of Halimeda tuna (Chlorophyceae, Caulerpales) from the northwestern Mediterranean. Collectanea Botanica 20, 5-21.

Ballesteros, E. 1991c. Seasonality of growth and production of a deep-water population of Halimeda tuna (Chlorophyceae, Caulerpales) in the north-western Mediterranean. Botanica Marina 34, 291-301.

Ballesteros, E. 1992. Els vegetals i la zonació litoral: espècies, comunitats i factors que influeixen en la seva distribució. Arxius Secció Ciències 101, 1-616. Barcelona: Institut d'Estudis Catalans.

Ballesteros, E. 1993. Algues bentòniques i fanerògames marines. In Història Natural de l'Arxipèlag de Cabrera, J.A. Alcover et al. (eds), Monografies de la Societat d'Història Natural de Balears 2. Palma de Mallorca: CSIC-Ed. Moll, 503-530.

Ballesteros, E. 1998. Addicions a la fauna d'invertebrats bentònics de l'arxipèlag de Cabrera (Illes Balears, Mediterrània Occidental). Bolletí de la Societat d'Història Natural de les Balears 41, 41-48.

Ballesteros, E. 2004. Espècies marines invasores: un problema ambiental emergent a les Illes Balears. In $I V$ Jornades de Medi Ambient de les illes Balears. Ponències i Resums, G.X. Pons (ed.). Palma de Mallorca: Societat Història Natural Balears, 13-15.

Ballesteros, E. \& Rodríguez-Prieto, C. 1996. Presència d'Asparagopsis taxiformis (Delile) Trevisan a Balears. Bolletí de la Societat d'Història Natural de les Balears 39, 135-138.

Ballesteros, E., Sala, E., Garrabou, J. \& Zabala, M. 1998. Community structure and frond size distribution of a deep water stand of Cystoseira spinosa (Phaeophyta) in the northwestern Mediterranean. European Journal of Phycology 33, 121-128.

Ballesteros, E. \& Tomas, F. 1999. Avaluació de l'estat de les comunitats bentòniques de La Roja (Tossa de Mar, Girona) en vistes a la seva declaració com a reserva marina. Blanes: Centre d'Estudis Avançats de Blanes - CSIC. 


\section{ENRIC BALLESTEROS}

Ballesteros, E. \& Zabala, M. 1993. El bentos: el marc físic. In Història Natural de l'Arxipèlag de Cabrera, J.A. Alcover et al. (eds), Monografies de la Societat d'Història Natural de Balears 2. Palma de Mallorca: CSIC-Ed. Moll, 663-685.

Ballesteros, E., Zabala, M., Uriz, M. J., Garcia-Rubies, A. \& Turon, X. 1993. El bentos: les comunitats. In Història Natural de l'Arxipèlag de Cabrera, J.A. Alcover et al. (eds), Monografies de la Societat d'Història Natural de Balears 2. Palma de Mallorca: CSIC-Ed. Moll, 687-730.

Basso, D. \& Tomaselli, V. 1994. Palaeoecological potentiality of rhodoliths: a Mediterranean case history. Bollettino della Societè Paleontologica Italiana, Speciale Volume 2, 17-27.

Battiato, A., Cormaci, M., Furnari, G. \& Scamacca, B. 1979. Osservazioni sulla zonazione dei popolamenti fitobentonici di substrato duro della Penisola della Maddalena (Siracusa). Thalassia Salentina 9, 19-25.

Bavestrello, G., Bertone, S., Cattaneo-Vietti, R., Cerrano, C., Gaino, E. \& Zanzi, D. 1994. Mass mortality of Paramuricea clavata (Anthozoa, Cnidaria) on Portofino Promontory cliffs, Ligurian Sea, Mediterranean Sea. Marine Life 4, 15-19.

Becerro, M.A. \& Turon, X. 1992. Reproductive cycles of the ascidians Microcosmus sabatieri and Halocynthia papillosa in the northwestern Mediterranean. Pubblicazioni della Stazione Zoologica di Napoli I: Marine Ecology 13, 363-373.

Bell, J.D. 1983. Effects of depth and marine reserve fishing restrictions on the structure of a rocky fish assemblage in the north-western Mediterranean Sea. Journal of Applied Ecology 20, 357-369.

Bellan, G. 1964. Contribution à l'étude systématique, bionomique et écologique des annélides polychètes de la Méditerranée. Thèse Doctorat. Faculté Sciences Marseille.

Bellan-Santini, D. 1998. Ecology. In The Amphipoda of the Mediterranean, Part 4, S. Ruffo (ed.). Mémoires de l'Institut Océanographique (Monaco) 13, 869-894.

Belsher, T. \& Meinesz, A. 1995. Deep-water dispersal of the tropical alga Caulerpa taxifolia introduced into the Mediterranean. Aquatic Botany 51, 163-169.

Bibiloni, M.A., Olivella, I. \& Ros, J. 1984. Les esponges de les illes Medes. In Els Sistemes Naturals de les Illes Medes, J. Ros et al. (eds). Arxius Secció Ciències 73, Barcelona: Institut d'Estudis Catalans, 383-405.

Blanc, J.J. \& Molinier, R. 1955. Les formations organogènes construites superficielles en Méditerranée occidentale. Bulletin de l'Institut Océanographique (Monaco) 52 (1067), 1-26.

Boero, F., Balduzzi, A., Bavestrello, G., Caffa, B. \& Vieti, R. 1986. Population dynamics of Eudendrium glomeratum (Cnidaria, Anthomedusae) on the Portofino promontory (Ligurian Sea). Marine Biology 92, 81-85.

Bosence, D.W.J. 1985. The "coralligène" of the Mediterranean - a recent analog for Tertiary coralline algal limestones. In Paleoalgology: Contemporary Research and Applications, D.F. Toomey \& M.H. Nicketi (eds), Heidelberg: Springer-Verlag, 216-225.

Boudouresque, C.F. 1970. Recherches sur bionomie analytique, structurale et expérimentale sur les peuplements benthiques sciaphiles en Méditerranée occidentale (fraction algale). Thèse. Université d'AixMarseille II.

Boudouresque, C.F. 1971. Méthodes d'étude qualitative et quantitative du benthos (en particulier du phytobenthos). Téthys 3, 79-104.

Boudouresque, C.F. 1973. Recherches de bionomie analytique, structurale et expérimentale sur les peuplements benthiques sciaphiles de Méditerranée Occidentale (fraction algale). Les peuplements sciaphiles de mode relativement calme sur substrats durs. Bulletin du Muséum d'Histoire Naturelle de Marseille 33, 147-225.

Boudouresque, C.F. 1980. Phytocénoses benthiques de la Réserve de Scandola. Compte-rendu de la mission rara-avis sur la façade maritime du Parc Naturel Régional de Corse. Marseille: Parc Naturel Régional de la Corse et Laboratoire Biologie Végétale Marine Luminy.

Boudouresque, C.F. 1985. Groupes écologiques d'algues marines et phytocenoses benthiques en Méditerranée nord-occidentale: une revue. Giornale Botanico Italiano 118, 7-42.

Boudouresque, C.F. 2004a. Marine biodiversity in the Mediterranean: status of species, populations and communities. Scientific Reports of Port-Cros National Park 20, 97-146. 


\section{MEDITERRANEAN CORALLIGENOUS ASSEMBLAGES}

Boudouresque, C.F. 2004b. The erosion of Mediterranean biodiversity. In The Mediterranean Sea: An Overview of Its Present State and Plans for Future Protection. Lectures from the 4th International Summer School on the Environment, C. Rodríguez-Prieto \& G. Pardini (eds), Girona: Universitat de Girona, 53-112.

Boudouresque, C.F., Avon, M. \& Gravez, V. (eds). 1991. Les espèces marines à protéger en Méditerranée. Marseille: GIS Posidonie.

Boudouresque, C.F. \& Cinelli, F. 1976. Le peuplement algal des biotopes sciaphiles superficiels de mode battu en Méditerranée Occidentale. Pubblicazione Stazione Zoologica di Napoli 40, 433-459.

Boudouresque, C.F. \& Denizot, M. 1975. Révision du genre Peyssonnelia (Rhodophyta) en Méditerranée. Bulletin Muséum d'Histoire Naturelle de Marseille 35, 7-92.

Boudouresque, C.F., Meinesz, A., Ballesteros, E., Ben Maiz, N., Boisset, F., Cinelli, F., Cirik, S., Cormaci, M., Jeudy de Grissac, A., Laborel, J., Lanfranco, E., Lundberg, B., Mayhoub, H., Panayotidis, P., Semroud, R., Sinnassamy, J.M. \& Span, A. 1990. Livre Rouge "Gérard Vuignier" des végétaux, peuplements et paysages marins menacés de Méditerranée. MAP Technical Report Series, 43. Athens: UNEP/IUCN/GIS Posidonie, 1-250.

Boudouresque, C.F. \& Ribera, M.A. 1994. Les introductions d'espèces végétales et animales en milieu marin. Conséquences écologiques et économiques et problèmes législatifs. In First International Workshop on Caulerpa taxifolia, C.F. Boudouresque et al. (eds), Marseille: GIS Posidonie, 29-102.

Boudouresque, C.F. \& Verlaque, M. 1978. Végétation marine de la Corse (Méditerranée). I. Documents pour la flore des algues. Botanica Marina 21, 265-275.

Boudouresque, C.F. \& Verlaque, M. 2002. Biological pollution in the Mediterranean Sea: invasive versus introduced macrophytes. Marine Pollution Bulletin 44, 32-38.

Bramanti, L., Magagnini, G., De Maio, L. \& Santangelo, G. 2005. Recruitment, early survival and growth of the Mediterranean red coral Corallium rubrum (L. 1758), a 4-year study. Journal of Experimental Marine Biology and Ecology 314, 69-78.

Bressan, G. \& Babbini-Benussi, L. 1996. Phytoceanographical observations on coralline algae (Corallinales) in the Mediterranean Sea. Rendiconti Lincei Scienze Fisiche e Naturali 9, 179-207.

Cabioch, J. \& Mendoza, M.L. 1998. Mesophyllum alternans (Foslie) comb. nov. (Corallinales, Rhodophyta), a mediterraneo-atlantic species, and new considerations on the Lithothamnion philippii Foslie complex. Phycologia 37, 208-221.

Cabioch, J. \& Mendoza, M.L. 2003. Mesophyllum expansum (Philippi) comb. nov. (Corallinales, Rhodophytes), et mise au point sur les Mesophyllum des mers d'Europe. Cahiers Biologie Marine 44, 257-273.

Canals, M. \& Ballesteros, E. 1997. Production of carbonate sediments by phytobenthic communities in the Mallorca-Minorca Shelf, northwestern Mediterranean Sea. Deep-Sea Research II 44, 611-629.

Canals, M., Ballesteros, E., Serra, J., Alonso, B. \& Catafau, E. 1988. The Pollensa Bay carbonate factory (Balearic islands, NW Mediterranean Sea). Rapports et Procès-Verbaux des Réunions Commission Internationale pour l'Exploration Scientifique de la Mer Méditerranée 31, 298.

Carbonell, J. 1984. Crustacis de les illes Medes. In Els Sistemes Naturals de les Illes Medes, J. Ros et al. (eds), Arxius Secció Ciències 73, 505-530.

Carpine, C. 1964. Contribution à l'étude bionomique de la Méditerranée occidentale (côte du Var et des AlpesMaritimes, côte occidentale de Corse). (3) La côte de l'Estérel, de la pointe des Lions à la pointe de l'Aiguille (région A2). Bulletin de l'Institut Océanographique (Monaco) 63 (1312), 1-52.

Cebrian, E., Ballesteros, E. \& Canals, M. 2000. Shallow rocky bottom benthic assemblages as calcium carbonate producers in the Alboran Sea (southwestern Mediterranean). Oceanologica Acta 23, 311-322.

Cerrano, C. Bavestrello, G., Bianchi, C.N., Cattaneo-Vietti, R., Bava, S., Morganti, C., Morri, C., Picco, P., Sara, G., Schiaparelli, S., Siccardi, A. \& Sponga, F. 2000. A catastrophic mass-mortality episode of gorgonians and other organisms in the Ligurian Sea (NW Mediterranean), summer 1999. Ecology Letters 3, 284-293.

Cerrano, C., Bavestrello, G., Cicogna, F. \& Cattaneo-Vietti, R. 1999. New experiences on transplantation and red coral harvesting effects in the Ligurian Sea. In Red Coral and Other Mediterranean Octocorals, Biology and Protection, F. Cicogna \& R. Cattaneo-Vietti (eds), Roma: Ministerio Politiche e Risorse Agricole Alimentari e Forestali, 62-67. 


\section{ENRIC BALLESTEROS}

Cerruti, A. 1921. Ulteriori notizie biologiche riguardanti il periodo de imaturità sessuale degli animale del golfo di Napoli. Pubblicazioni della Stazione Zoologica di Napoli 3, 229-240.

Chauvet, C. 1991. Statut d'Epinephelus guaza (Linnaeus, 1757) et éléments de dynamiques des populations méditerranéenne et atlantique. In Les Espèces Marines à Protéger en Méditérranée, C.F. Boudouresque et al. (eds), Marseille: GIS Posidonie, 255-275.

Chazottes, V., Le Campion-Alsumard, T. \& Peyrot-Clausade, M. 1995. Bioerosion rates on coral reefs: interactions between macroborers, microborers and grazers (Moorea, French Polynesia). Paleogeography Paleoclimatology Paleoecology 113, 189-198.

Chintiroglou, H., Dounas, C. \& Koukouras, A. 1989. The presence of Corallium rubrum (Linnaeus, 1758) in the eastern Mediterranean sea. Mitteilungen aus dem Zoologischen Museum Berlin 65, 145-149.

Coll, J., Garcia-Rubies, A., Moranta, J., Stefanni, S. \& Morales-Nin, B. 1999. Efectes de la prohibició de la pesca esportiva sobre l'estructura poblacional de l'anfós (Epinephelus marginatus Lowe, 1834. Pisces, Serranidae) en el Parc Nacional de Cabrera. Bolletí de la Societat d'Història Natural de les Balears 42, 125-138.

Coma, R., Gili, J.M., Zabala, M. \& Riera, T. 1994. Feeding and prey capture cycles in the aposymbiontic gorgonian Paramuricea clavata. Marine Ecology Progress Series 115, 257-270.

Coma, R., Llobet, I., Zabala, M., Gili, J.M. \& Hughes, R.G. 1992. The population dynamics of Halecium petrosum and Halecium pusillum (Hydrozoa, Cnidaria), epiphytes of Halimeda tuna in the northwestern Mediterranean. Scientia Marina 56, 161-169.

Coma, R., Polà, E., Ribes, M. \& Zabala, M. 2004. Long-term assessment of temperate octocoral mortality patterns, protected vs. unprotected areas. Ecological Applications 14, 1466-1478.

Coma, R. \& Ribes, M. 2003. Seasonal energetic constraints in Mediterranean benthic suspension feeders: effects at different levels of ecological organization. Oikos 101, 205-215.

Coma, R., Ribes, M., Gili, J.M. \& Zabala, M. 1998a. An energetic approach to the study of life-history traits of two modular colonial benthic invertebrates. Marine Ecology Progress Series 162, 89-103.

Coma, R., Ribes, M., Gili, J.M. \& Zabala, M. 2000. Seasonality in coastal benthic ecosystems. Trends in Ecology and Evolution 15, 448-453.

Coma, R., Ribes, M., Gili, J. M. \& Zabala, M. 2002. Seasonality of in situ respiration rate in three temperate benthic suspension feeders. Limnology and Oceanography 47, 324-331.

Coma, R., Ribes, M., Zabala, M. \& Gili, J.M. 1995a. Reproduction and cycle of gonadal development in the Mediterranean gorgonian Paramuricea clavata. Marine Ecology Progress Series 117, 173-183.

Coma, R., Ribes, M., Zabala, M. \& Gili, J.M. 1998b. Growth in a modular colonial marine invertebrate. Estuarine Coastal and Shelf Science 47, 459-470.

Coma, R., Zabala, M. \& Gili, J M. 1995b. Sexual reproductive effort in the Mediterranean gorgonian Paramuricea clavata. Marine Ecology Progress Series 117, 185-192.

Coppejans, E. \& Hermy, M. 1985. L'épiflore des substrats de l'étage circalittoral dans la baie de Calvi (Corse, Méditerranée). V. Ordination et classification des données. In Progress in Belgian Oceanographic Research: Proceedings of a Symposium held at the Palace of Academies Brussels 3-5 March 1985, R. Van Griecken \& R. Wollast (eds), Antwerpen: University of Antwerp, 430-441.

Corbera, J., Ballesteros, E. \& Garcia, L. 1993. Els crustacis decàpodes. In Història Natural de l'Arxipèlag de Cabrera, J. A. Alcover et al. (eds), Monografies de la Societat d'Història Natural de Balears 2. Palma de Mallorca: CSIC-Ed. Moll, 579-587.

Corbera, J., Sabates, A. \& Garcia-Rubies, A. 1996. Peces de Mar de la Península Ibérica. Barcelona: Planeta.

Cormaci, M., Furnari, G. \& Scamacca, B. 1985. Osservazioni sulle fitocenosi bentoniche del golfo di Augusta (Siracusa). Bollettino dell'Accademia Gioenia Scienze Naturalli 18, 851-872.

Dethier, M.N., Paul, K.M. \& Woodbury, M.M. 1991. Distribution and thickness patterns in subtidal encrusting algae from Washington. Botanica Marina 34, 201-210.

Dring, M.J. 1981. Chromatic adaptation of photosynthesis in benthic marine algae: an examination of its ecological significance using a theoretical model. Limnology and Oceanography 26, 271-284.

Feldmann, J. 1937. Recherches sur la Végétation Marine de la Méditerranée: la Côte des Albères. Rouen: Wolf.

Ferdeghini, F., Acunto, S., Cocito, S. \& Cinelli, F. 2000. Variability at different spatial scales of a coralligenous assemblage at Giannutri island (Tuscan Archipelago, northwestern Mediterranean). Hydrobiologia 440, 27-36. 


\section{MEDITERRANEAN CORALLIGENOUS ASSEMBLAGES}

Ferrer, E., Ribera, M.A. \& Gómez-Garreta, A. 1994. The spread of Acrothamnion preissii (Sonder) Wollaston (Rhodophyta, Ceramiaceae) in the Mediterranean Sea: new record from the Balearic islands. Flora Mediterranea 4, 163-166.

Finckh, A.E. 1904. Biology of the reef-forming organisms at Funafuti Atoll, Part VI. In The Atoll of Funafuti: Borings into a Coral Reef and the Results, Royal Society of London. London: Harrison \& Sons, $125-150$.

Foslie, M.H. 1907. The Lithothamnia. In Reports of the Percy Sladen Trust Expedition to the Indian Ocean in 1905, J.S. Gardiner (ed.), Transactions of the Linnean Society of London, Series 2 (Zoology) 12, 177-192.

Francour, P. 1991. Statut de Centrostephanus longispinus en Méditerranée. In Les Espèces Marines à Protéger en Méditérranée, C.F. Boudouresque et al. (eds), Marseille: GIS Posidonie, 187-202.

Francour, P. 1994. Pluriannual analysis of the reserve effect on ichthyofauna in the Scandola natural reserve (Corsica, Northwestern Mediterranean). Oceanologica Acta 17, 309-317.

Fredj, G. 1964. Contribution à l'étude bionomique de la Méditerranée Occidentale (côte du Var et des AlpesMaritimes, côte occidentale de Corse). Fasc. 2. La région de Saint Tropez; du Cap Taillat au Cap de Saint Tropez (région A1). Bulletin de l'Institut Océanographique (Monaco) 63 (1311), 1-55.

Furnari, G., Cormaci, M. \& Alongi, G. 1996. Lithophyllum frondosum (Dufour) comb. nov. (Corallinaceae, Rhodophyta): the species to which Mediterranean "Pseudolithophyllum expansum" should be referred. European Journal of Phycology 31, 117-122.

Furnari, G., Scamacca, B., Cormaci, M. \& Battiato, A. 1977. Zonazione della vegetazione sommersa dell'isola Lachea (Catania). Atti XI Congresso della Società Italiana di Biologia Marina, 245-257.

Gamulin-Brida, H. 1965. Contribution aux recherches bionomiques sur les fonds coralligènes au large de l'Adriatique moyenne. Rapports et Procés-Verbaux des Réunions Commission Internationale pour l'Exploration Scientifique de la Mer Méditerranée 18 (2), 69-74.

Gamulin-Brida, H. 1967. The benthic fauna of the Adriatic Sea. Oceanography and Marine Biology: An Annual Review 5, 535-568.

García-Raso, J.E. 1988. Consideraciones generales sobre la taxocenosis de crustáceos decápodos de fondos de concrecionamiento calcáreo superficial del alga Mesophyllum lichenoides (Ellis \& Sol.) Lemoine (Corallinaceae) del mar de Alborán. Investigación Pesquera 52, 245-264.

García-Raso, J.E. 1989. Resultados de la segunda campaña del I.E.O. para la exploración de los fondos de coral rojo en el mar de Alborán. Crustáceos decápodos. Boletín Instituto Español de Oceanografía 5, 27-36.

García-Raso, J.E. \& Fernández-Muñoz, R. 1987. Estudio de una comunidad de crustáceos decápodos de fondos "coralígenos" del alga calcárea Mesophyllum lichenoides del sur de España. Investigación Pesquera 51 (Suplemento 1), 301-322.

García-Raso, J.E., López de la Rosa, I. \& Rosales, J.M. 1996. Decapod crustacean communities from calcareous seaweed and Posidonia oceanica (rhizome stratum) in shallow waters. Ophelia 45, 143-158.

García-Rodríguez, M. \& Massó, C. 1986. Estudio biométrico de poblaciones de coral rojo del litoral de Gerona. Boletín Instituto Español de Oceanografía 3, 65-74.

Garcia-Rubies, A. 1993. Distribució batimètrica dels peixos litorals sobre substrat rocòs a l'illa de Cabrera. In Història Natural de l'Arxipèlag de Cabrera, J.A. Alcover et al. (eds), Monografies de la Societat d'Història Natural de Balears 2. Palma de Mallorca: CSIC-Ed. Moll, 645-661.

Garcia-Rubies, A. 1997. Estudi ecològic de les poblacions de peixos litorals sobre substrat rocòs a la Mediterrània occidental: efectes de la fondària, el substrat, l'estacionalitat $i$ la protecció. Tesi Doctoral. Universitat de Barcelona.

Garcia-Rubies, A. 1999. Effects of fishing on community structure on selected populations of Mediterranean coastal reef fish. Naturalista Siciliano 23, 59-81.

Garcia-Rubies, A. \& Zabala, M. 1990. Effects of total fishing prohibition on the rocky fish assemblages of Medes islands marine reserve. Scientia Marina 54, 317-328.

Garrabou, J. 1997. Structure and dynamics of north-western Mediterranean rocky benthic communities along a depth gradient: a Geographical Information System (GIS) approach. PhD Thesis. University of Barcelona. 


\section{ENRIC BALLESTEROS}

Garrabou, J. 1999. Life history traits of Alcyonium acaule and Parazoanthus axinellae (Cnidaria, Anthozoa), with emphasis on growth. Marine Ecology Progress Series 178, 193-204.

Garrabou, J. \& Ballesteros, E. 2000. Growth of Mesophyllum alternans and Lithophyllum frondosum (Corallinaceae, Rhodophyta) in the northwestern Mediterranean. European Journal of Phycology 35, 1-10.

Garrabou, J., Ballesteros, E. \& Zabala, M. 2002. Structure and dynamics of north-western Mediterranean benthic communities along a depth gradient. Estuarine Coastal and Shelf Science 55, 493-508.

Garrabou, J. \& Harmelin, J.G. 2002. A 20-year study on life history traits of a harvested long-lived temperate coral in the NW Mediterranean: insights into conservation and management needs. Journal of Animal Ecology 71, 966-978.

Garrabou, J., Perez, T., Sartoretto, S. \& Harmelin, J.G. 2001. Mass mortality event in red coral (Corallium rubrum, Cnidaria, Anthozoa, Octocorallia) population in the Provence region (France, NW Mediterranean). Marine Ecology Progress Series 217, 263-272.

Garrabou, J., Sala, E., Arcas, A. \& Zabala, M. 1998. The impact of diving on rocky sublittoral communities: a case study of a bryozoan population. Conservation Biology 12, 302-312.

Garrabou, J. \& Zabala, M. 2001. Growth dynamics in four Mediterranean demosponges. Estuarine Coastal and Shelf Science 52, 293-303.

Gautier, Y.V. 1962. Recherches écologiques sur les bryozoaires chilostomes en Méditerranée Occidentale. Recueil des Travaux de la Station Marine d'Endoume 24 (38), 1-434.

Giaccone, G. 1965. Le fitocenosi marine nel settore rosso di Capo Zafferano (Palermo). Lavori Istituto Botanico di Palermo 22, 1-69.

Giaccone, G. 1967. Popolamenti a Laminaria rodriguezii Bornet sul banco Apollo dell'isola di Ustica (Mar Tirreno). Nova Thalassia 3, 1-10.

Giaccone, G., Alongi, G., Pizzuto, F. \& Cossu, A. 1994. La vegetazione marina bentonica sciafila del Mediterraneo: III. Infralitorale e circalitorale. Proposte di aggiornamento. Bollettino dell'Accademia Gioenia Scienze Naturalli 27, 201-227.

Giaccone, G. \& De Leo, A. 1966. Flora e vegetazione algale del Golfo di Palermo. Lavori Istituto Botanico di Palermo 22, 251-317.

Gili, J.M. 1986. Estudio sistemático y faunístico de los cnidarios de la costa catalana. Tesis Doctoral. Universidad Autónoma de Barcelona.

Gili, J.M. \& Ballesteros, E. 1991. Structure of cnidarian populations in Mediterranean sublittoral benthic communities as a result of adaptation to different environmental conditions. Oecologia Aquatica 10, 243-254.

Gili, J.M., Garcia, A. \& Colomer, P. 1984. Els cnidaris bentònics de les illes Medes. In Els Sistemes Naturals de les Illes Medes, J. Ros et al. (eds), Arxius Secció Ciències 73, 407-427.

Gili, J.M., Murillo, J. \& Ros, J. 1989. The distribution pattern of benthic cnidarians in the western Mediterranean. Scientia Marina 53, 19-35.

Gili, J.M. \& Ros, J. 1984. L'estatge circalitoral de les illes Medes: el coral-ligen. In Els Sistemes Naturals de les Illes Medes, J. Ros et al. (eds), Arxius Secció Ciències 73, 677-705.

Gili, J.M. \& Ros, J. 1985. Study and cartography of the benthic communities of Medes islands (NE Spain). Pubblicazzioni della Stazione Zoologica di Napoli I: Marine Ecology 6, 219-238.

Got, H. \& Laubier, L. 1968. Prospection sysmique au large des Albères: nature du substrat originel du coralligène. Vie et Milieu 19, 9-16.

Hamel, G. \& Lemoine, P. 1953. Corallinacées de France et d'Afrique du Nord. Archives du Muséum National d'Histoire Naturelle, Paris, 7 série 1, 15-136.

Harmelin, J.G. 1990. Ichthyofaune des fonds rocheux de Méditerranée: structure du peuplement du coralligène de l'île de Port-Cros (Parc National). Mesogée 50, 23-30.

Harmelin, J.G. 1991. Statut du corb (Sciaena umbra) en Méditerranée. In Les Espèces Marines à Protéger en Méditérranée, C. F. Boudouresque et al. (eds), Marseille: GIS Posidonie, 219-227.

Harmelin, J.G. 1993. Invitation sous l'écume. Cahiers Parc National Port-Cros 10, 1-83.

Harmelin, J.G., Bouchon, C., Duval, C. \& Hong, J.S. 1980. Les échinodermes des substrats durs de l'île de Port-Cros, parc national. Eléments pour un inventaire qualitatif. Travaux Scientifiques Parc National Port-Cros 6, 25-38. 


\section{MEDITERRANEAN CORALLIGENOUS ASSEMBLAGES}

Harmelin, J.G. \& Marinopoulos, J. 1994. Population structure and partial mortality of the gorgonian Paramuricea clavata (Risso) in the north-western Mediterranean (France, Port-Cros Island). Marine Life 4, 5-13.

Harmelin, J.G. \& Robert, P. 2001. Evolution récente de la population du mérou brun (Epinephelus marginatus) dans le Parc national de Port-Cros (France, Méditerranée). Scientific Reports Port-Cros National Park 18, 149-161.

Hillis-Colinvaux, L. 1986. Historical perspectives on algae and reefs: have reefs been misnamed? Oceanus 29, 43-48.

Hong, J.S. 1980. Étude faunistique d'un fond de concrétionnement de type coralligène soumis à un gradient de pollution en Méditerranée nord-occidentale (Golfe de Fos). Thèse de Doctorat. Université d'AixMarseille II.

Hong, J S. 1982. Contribution à l'étude des peuplements d'un fond coralligène dans la région marseillaise en Méditerranée Nord-Occidentale. Bulletin of Korea Ocean Research and Development Institute 4, 27-51.

Hong, J.S. 1983. Impact of the pollution on the benthic community: environmental impact of the pollution on the benthic coralligenous community in the Gulf of Fos, northwestern Mediterranean. Bulletin of the Korean Fisheries Society 16, 273-290.

Hrs-Brenko, M., Zavodnik, D. \& Zahtila, E. 1991. The date shell Lithophaga lithophaga Linnaeus, and its habitat calls for protection in the Adriatic sea. In Les Espèces Marines à Protéger en Méditérranée, C. F. Boudouresque et al. (eds), Marseille: GIS Posidonie, 151-158.

Huelin, M.F. \& Ros, J. 1984. Els mol-luscs marins de les illes Medes. In Els Sistemes Naturals de les Illes Medes, J. Ros et al. (eds), Arxius Secció Ciències 73, 457-504.

James, N.P., Wray, J.L. \& Ginsburg, R.N. 1988. Calcification of encrusting aragonitic algae (Peyssonneliaceae): implications for the origin of late Paleozoic reefs and cements. Journal of Sedimentary Petrology 58, 291-303.

Jimeno, A. \& Turon, X. 1995. Gammaridea and Caprellidae of the northeast coast of Spain: ecological distribution on different types of substrata. Polskie Archiwum Hydrobiologii 42, 495-516.

Kleeman, K.H. 1973. Lithophaga lithophaga (L.) (Bivalvia) in different limestones. Malacologia 14, 345-347.

Laborel, J. 1960. Contribution à l'étude directe des peuplements benthiques sciaphiles sur substrat rocheux en Méditerranée. Recueil des Travaux de la Station Marine d'Endoume 20 (33), 117-174.

Laborel, J. 1961. Le concretionnement algal "coralligène" et son importance géomorphologique en Méditerranée. Recueil des Travaux de la Station Marine d'Endoume 23 (37), 37-60.

Laborel, J. 1987. Marine biogenic constructions in the Mediterranean. Scientific Reports of Port-Cros National Park 13, 97-126.

Laborel, J., Morhange, C., Lafont, R., Le Campion, J., Laborel-Deguen, F. \& Sartoretto, S. 1994. Biological evidence of sea-level rise during the last 4500 years on the rocky coasts of continental southwestern France and Corsica. Marine Geology 120, 203-223.

Lacaze-Duthiers, H. 1864. Histoire Naturelle du Corail. Paris: J.B. Baillière.

Laubier, L. 1959a. Contribution à la faunistique du coralligène. I. Quelques particularités biologiques de Polydora armata Langerhans. Vie et Milieu 9, 412-415.

Laubier, L. 1959b. Contribution à la faunistique du coraligène. III. Deux spionidiens inquilins sur des bryozoaires chilostomides. Vie et Milieu 10, 347-349.

Laubier, L. 1960. Une nouvelle espèce de syllidien: Haplosyllis depressa Augener ssp. nov. chamaeleon, ectoparasite sur l'octocorallaire Muricea chamaeleon von Koch. Vie et Milieu 11, 75-87.

Laubier, L. 1966. Le coralligène des Albères: monographie biocénotique. Annales de l'Institut Océanographique de Monaco 43, 139-316.

Lebednik, P.A. 1977. The Corallinaceae of northwestern North America. I. Clathromorphum Foslie emend. Adey. Syesis 9, 59-112.

Lee, R.K.S. 1967. Taxonomy and distribution of the melobesioid algae on Rongelap Atoll, Marshall Islands. Canadian Journal of Botany 45, 985-1001.

Linares, C., Coma, R., Diaz, D., Zabala, M., Hereu, B. \& Dantart, L. 2005. Immediate and delayed effects of mass mortality event on gorgonian population dynamics and benthic community structure in the NW Mediterranean. Marine Ecology Progress Series 305, 127-137. 


\section{ENRIC BALLESTEROS}

Littler, M.M. 1972. The crustose Corallinaceae. Oceanography and Marine Biology: An Annual Review 10, 311-347.

Littler, M.M. 1973a. The distribution, abundance, and communities of deepwater Hawaiian crustose Corallinaceae (Rhodophyta, Cryptonemiales). Pacific Science 27, 281-289.

Littler, M.M. 1973b. The population and community structure of Hawaiian fringing-reef crustose Corallinaceae (Rhodophyta, Cryptonemiales). Journal of Experimental Marine Biology and Ecology 11, 103-120.

Littler, M.M. 1976. Calcification and its role among the macroalgae. Micronesica 12, 27-41.

Littler, M.M. \& Doty, M.S. 1975. Ecological components structuring the seaward edges of tropical Pacific reefs: the distribution, communities and productivity of Porolithon. Journal of Ecology 63, 117-129.

Littler, M.M., Littler, D.S., Blair, S.M. \& Norris, J.N. 1986. Deep-water plant communities from an uncharted seamount off San Salvador Island, Bahamas: distribution, abundance, and primary productivity. DeepSea Research 33, 881-892.

Lo Bianco, S. 1909. Notizie biologiche riguardanti specialmente il periodo di maturità sessuale degli animali del golfo di Napoli. Pubblicazioni della Stazione Zoologica di Napoli 19, 513-692.

Logan, A. 1979. The recent Brachiopoda of the Mediterranean Sea. Bulletin de l'Institut Océanographique (Monaco) 72 (1434), 1-112.

Llobet, I., Gili, J.M. \& Hughes, R.G. 1991a. Horizontal, vertical and seasonal distributions of epiphytic Hydrozoa on the alga Halimeda tuna in the northwestern Mediterranean Sea. Marine Biology 110, 151-159.

Llobet, I, Coma, R., Zabala, M., Gili, J.M. \& Hughes, R.G. 1991b. The population dynamics of Orthopyxis crenata (Hartlaub, 1901) (Hydrozoa, Cnidaria), an epiphyte of Halimeda tuna in the northwestern Mediterranean. Journal of Experimental Marine Biology and Ecology 150, 283-292.

Lüning, K. 1981. Light. In The Biology of Seaweeds, C.S. Lobban \& M.J. Wynne (eds), London \& Oxford: Blackwell Scientific, 326-355.

Maldonado, M. 1992. Demosponges of the red coral bottoms from the Alboran Sea. Journal of Natural History 26, 1131-1161.

Mariani, S. \& Uriz, M.J. 2001. Copepods of the genus Asterocheres (Copepoda: Siphonostomatoida) feeding on sponges: behavioral and ecological traits. Invertebrate Biology 120, 269-277.

Marino, G., Di Martino, V. \& Giaccone, G. 1998. La vegetazione marina nella Penisola Maddalena (Siracusa, Sicilia SE). Bollettino dell'Accademia Gioenia Scienze Naturalli 31, 235-287.

Marion, A.F. 1883. Esquisse d'une topographie zoologique du Golfe de Marseille. Annales Musée d'Histoire Naturelle Marseille 1, 1-108.

Marschal, C., Garrabou, J., Harmelin, J.G. \& Pichon, M. 2005. A new method for measuring growth and age in the precious red coral Corallium rubrum (L.). Coral Reefs 23, 423-432.

Marshall, J.P. 1983. The fate of borings: relations between bioerosion, internal sediment infill and submarine cementation. In Proceedings of the Inaugural GBR Conference, J.T. Baker et al. (eds), Townsville: James Cook University Press, 129-234.

Martí, R. 2002. Spatial and temporal variability of the natural toxicity in benthic communities of Mediterranean caves. PhD Thesis. University of Barcelona.

Martí, R., Uriz, M.J., Ballesteros, E. \& Turon, X. 2004. Benthic assemblages in two Mediterranean caves: species diversity and coverage as a function of abiotic parameters and geographic distance. Journal of the Marine Biological Association of the United Kingdom 84, 557-572.

Martí, R., Uriz, M.J., Ballesteros, E. \& Turon, X. 2005. Seasonal variation in structure of three algal communities under different light conditions. Estuarine Coastal and Shelf Science 64, 613-622.

Martin, D. 1987. La comunidad de anélidos poliquetos de las concreciones de algas calcáreas del litoral catalán. Caracterización de las especies. Publicaciones del Departamento de Zoología de la Universidad de Barcelona 13, 45-54.

Martin, D. 1996. A new species of Polydora (Polychaeta, Spionidae) associated with the excavating sponge Cliona viridis (Porifera, Hadromerida) in the north-western Mediterranean Sea. Ophelia 45, 159-174.

Martin, D. \& Britayev, T.A. 1998. Symbiotic polychaetes: review of known species. Oceanography and Marine Biology: An Annual Review 36, 217-340.

Martin, D., Dantart, L. \& Ballesteros, M. 1990. Moluscos de las concreciones de algas calcáreas del litoral catalán (NE España). Lavori Società Italiana di Malacologia 23, 445-456. 


\section{MEDITERRANEAN CORALLIGENOUS ASSEMBLAGES}

Mayol, J., Grau, A., Riera, F. \& Oliver, J. 2000. Llista vermella dels peixos de les Balears. Quaderns de Pesca 4, 1-126.

Meinesz, A. 1999. Killer Algae: The True Tale of a Biological Invasion. Chicago \& London: University of Chicago.

Meinesz, A. \& Hesse, B. 1991. Introduction et invasion de l'algue tropicale Caulerpa taxifolia en Méditerranée nord-occidentale. Oceanologica Acta 14, 415-426.

Mistri, M. \& Ceccherelli, V.U. 1994. Growth and secondary production of the Mediterranean gorgonian Paramuricea clavata. Marine Ecology Progress Series 103, 291-296.

Molinier, R. 1956. Les fonds à laminaires du Grand Banc de Centuri (Cap Corse). Comptes Rendus de l'Académie des Sciences 342, 939-941.

Molinier, R. 1960. Étude des biocénoses marines du Cap Corse. Vegetatio 9, 212-312.

Montserrat, A. 1984. Els equinoderms de les illes Medes. In Els Sistemes Naturals de les Illes Medes, J. Ros et al. (eds), Arxius Secció Ciències 73, 563-580.

Munar, J. 1993. Els equinoderms. In Història Natural de l'Arxipèlag de Cabrera, J.A. Alcover et al. (eds), Monografies de la Societat d'Història Natural de Balears 2. Palma de Mallorca: CSIC-Ed. Moll, 597-606.

Munilla, T. \& De Haro, A. 1984. Picnogònids de les illes Medes. In Els Sistemes Naturals de les Illes Medes, J. Ros et al. (eds), Arxius Secció Ciències 73, 531-536.

Nikolic, M. 1960. Hippodiplosia foliacea Solander, 1876 (Bryozoa), comme centre d'association sur un fond coralligène dans l'Adriatique. Rapport et Procès Verbaux des Réunions Commission Internationale pour l'Exploration Scientifique de la Mer Méditerranée 15 (2), 85-86.

Odum, H.T. \& Odum E.P. 1955. Trophic structure and productivity of a windward coral reef community on Eniwetok Atoll. Ecological Monographs 25, 291-320.

Ortiz, A., Massó, C., Soriano, O. \& Limia, J. 1986. La barra italiana como arte de pesca del coral rojo (Corallium rubrum L.) en el mar de Alborán (SE de España). Boletín Instituto Español de Oceanografía 3, 83-92.

Palanques, A., Guillén, J. \& Puig, P. 2001. Impact of bottom trawling on water turbidity and muddy sediment of an unfished continental shelf. Limnology and Oceanography 46, 1100-1110.

Parenzan, P. 1960. Aspetti biocenotici dei fondi ad alghe litoproduttrici del Mediterraneo. Rapport et Procès Verbaux des Réunions Commission Internationale pour l'Exploration Scientifique de la Mer Méditerranée 15 (2), 87-107.

Pascual, J. \& Flos, J. 1984. Metereologia i Oceanografia. In Els Sistemes Naturals de les Illes Medes, J. Ros, I. Olivella \& J.M. Gili (eds), Arxius Secció Ciències 73, 75-114.

Patzner, R.A. 1998. The invasion of Lophocladia (Rhodomelaceae, Lophotalieae) at the northern coast of Ibiza (Western Mediterranean Sea). Bolletí de la Societat d'Història Natural de les Balears 41, 75-80.

Patzner, R.A. 1999. Habitat utilization and depth distribution of small cryptobenthic fishes (Blenniidae, Gobiidae, Trypyterigiidae) in Ibiza (western Mediterranean Sea). Environmental Biology of Fishes 55, 207-214.

Pérès, J. 1967. The Mediterranean benthos. Oceanography and Marine Biology: An Annual Review 5, 449-533.

Pérès, J. \& Picard, J.M. 1951. Notes sur les fonds coralligènes de la région de Marseille. Archives de Zoologie Expérimentale et Générale 88, 24-38.

Pérès, J. \& Picard, J.M. 1952. Les corniches calcaires d'origine biologique en Méditerranée Occidentale. Recueil des Travaux de la Station Marine d'Endoume 4, 2-33.

Pérès, J. \& Picard, J.M. 1958 Recherches sur les peuplements benthiques de la Méditerranée nord-orientale. Annales de l'Institut Océanographique de Monaco 34, 213-291.

Pérès, J. \& Picard, J.M. 1964. Nouveau manuel de bionomie benthique de la mer Méditerranée. Recueil des Travaux de la Station Marine d'Endoume 31(47), 1-131.

Perez, T., Garrabou, J., Sartoretto, S., Harmelin, J.G., Francour, P. \& Vacelet, J. 2000. Mortalité massive d'invertébrés marins: un événement sans précédent en Méditerranée nord-occidentale. Comptes Rendus de l'Académie des Sciences Série III, Life Sciences 323, 853-865.

Piazzi, L., Balata, D., Pertusati, M. \& Cinelli, F. 2004. Spatial and temporal variability of Mediterranean macroalgal coralligenous assemblages in relation to habitat and substratum inclination. Botanica Marina 47, 105-115. 


\section{ENRIC BALLESTEROS}

Piazzi, L., Ceccherelli, G., Meinesz, A., Verlaque, M., Akali, B. Antolic, B., Argyrou, M., Balata, D., Ballesteros, E., Calvo, S., Cinelli, F., D’Archino, R., Djellouli, A.S., Javel, F., Mifsud, C., Pala, D., Panayotidis, P., Peirano, A., Pergent, G., Petrocelli, A., Ruitton, S. \& Zuljevic, A. 2005. Invasion of Caulerpa racemosa (Caulerpales, Chlorophyta) in the Mediterranean Sea: the balance of thirteen years of spread. Cryptogamie Algologie 26, 189-202.

Piazzi, L., Pardi, G., Balata, D., Cecchi, E. \& Cinelli, F. 2002. Seasonal dynamics of a subtidal north-western Mediterranean macroalgal community in relation to depth and substrate inclination. Botanica Marina 45, 243-252.

Piazzi, L., Pardi, G. \& Cinelli, F. 1996. Ecological aspects and reproductive phenology of Acrothamnion preissii (Sonder) Wollaston (Ceramiaceae, Rhodophyta) from the Tuscan Archipelago (Western Mediterranean). Cryptogamie Algologie 17, 35-43.

Pruvot, G. 1894. Sur les fonds sous-marins de la région de Banyuls et du cap de Creus. Comptes Rendus de l'Académie des Sciences 118, 203-206.

Pruvot, G. 1895. Coup d'oeil sur la distribution générale des invertébrés dans la région de Banyuls (Golfe du Lion). Archives de Zoologie Expérimentale et Générale 3, 629-658.

Pruvot, G. 1897. Essai sur les fonds et la faune de la Manche Occidentale (côtes de Bretagne) comparées à ceux du Golfe de Lion. Archives de Zoologie Expérimentale et Générale 5, 511-660.

Ramos, A.A. 1991. Ascidias litorales del Mediterráneo ibérico. Faunística, ecología y biogeografía. Tesis Doctoral. Universidad de Alicante.

Ribes, M., Coma, R. \& Gili, J.M. 1998. Seasonal variation of in situ feeding rates by the temperate ascidian Halocynthia papillosa. Marine Ecology Progress Series 175, 201-213.

Ribes, M., Coma, R. \& Gili, J.M. 1999a. Seasonal variation of particulate organic carbon, dissolved organic carbon and the contribution of microbial communities to the live particulate organic carbon in a shallow near-bottom ecosystem at the Northwestern Mediterranean Sea. Journal of Plankton Research 21, 1077-1100.

Ribes, M., Coma, R. \& Gili, J.M. 1999b. Natural diet and grazing rate of the temperate sponge Dysidea avara (Demospongiae, Dendroceratida) throughout an annual cycle. Marine Ecology Progress Series 176, 179-190.

Ribes, M., Coma, R. \& Gili, J.M. 1999c. Heterogenous feeding in benthic suspension feeders: the natural diet and grazing rate of the temperate gorgonian Paramuricea clavata (Cnidaria: Octocorallia) over a year cycle. Marine Ecology Progress Series 183, 125-137.

Riedl, R. 1966. Biologie der Meereshöhlen. Hamburg: Paul Parey.

Riera, F., Oliver, J. \& Terrassa, J. 1998. Peixos de les Balears. Palma de Mallorca: Govern Balear.

Riera, F., Pou, S. \& Grau, A.M. 1993. La ictiofauna. In Història Natural de l'Arxipèlag de Cabrera, J. A. Alcover et al. (eds), Monografies de la Societat d'Història Natural de Balears 2. Palma de Mallorca: CSIC-Ed. Moll, 623-644.

Rivoire, G. 1991. Mortalité du corail et des gorgones en profondeur au large des côtes provençales. In Les Espèces Marines à Protéger en Méditérranée, C.F. Boudouresque et al. (eds), Marseille: GIS Posidonie, 53-59.

Romano, J.C., Bensoussan, N., Younes, W.A.N. \& Arlhac, D. 2000. Anomalies thermiques dans les eaux du Golfe de Marseille durant l'été 1999. Une explication partielle de la mortalité des invertébrés fixés. Comptes Rendus de l'Académie des Sciences Série III, Life Sciences 323, 853-865.

Ros, J. 1978. La alimentación y el sustrato en los opistobranquios ibéricos. Oecologia Aquatica 3, 153-166.

Ros, J., Olivella, I. \& Gili, J.M. (eds). 1984. Els Sistemes Naturals de les Illes Medes. Arxius Secció Ciències 73, Barcelona: Institut d'Estudis Catalans.

Ros, J., Romero, J., Ballesteros, E. \& Gili, J.M. 1985. Diving in blue water: the benthos. In Western Mediterranean, R. Margalef (ed.), Oxford: Pergamon, 233-295.

Rosell, D. \& Uriz, M.J. 2002. Excavating and endolithic sponge species (Porifera) from the Mediterranean: species descriptions and identification key. Organisms Diversity and Evolution 2, 55-86.

Rosell, D., Uriz, M.J. \& Martin, D. 1999. Infestation by excavating sponges on the oyster (Ostrea edulis) populations of the Blanes littoral zone (northwestern Mediterranean Sea). Journal of the Marine Biological Association of the United Kingdom 79, 409-413. 


\section{MEDITERRANEAN CORALLIGENOUS ASSEMBLAGES}

Rossi, L. 1958. Osservazioni sul bentos coralligeno dei dintorni di Catania. Archivi di Oceanografia $e$ Limnologia 11, 161-165.

Rossi, L. 1961. Sur un faciès à gorgonaires de la pointe du Mesco (Golfe de Gènes) (note préliminaire). Rapports et Procés-Verbaux des Réunions Commission Internationale pour l'Exploration Scientifique de la Mer Méditerranée 16 (2), 517-521.

Rossi, S. 2001. Environmental factors affecting the trophic ecology of benthic suspension feeders. PhD Thesis. University of Barcelona.

Russo, G.F. \& Cicogna, F. 1991. The date mussel (Lithophaga lithophaga), a "case" in the Gulf of Naples. In Les Espèces Marines à Protéger en Méditérranée, C.F. Boudouresque et al. (eds), Marseille: GIS Posidonie, 141-150.

Rützler, K. 1976. Ecology of Tunisian commercial sponges. Tethys 7, 249-264.

Sala, E., Boudouresque, C.F. \& Harmelin-Vivien, M. 1998. Fishing, trophic cascades and the structure of algal assemblages: evaluation of an old but untested paradigm. Oikos 82, 425-439.

Sala, E., Garrabou, J. \& Zabala, M. 1996. Effects of diver frequentation on Mediterranean sublittoral populations of the bryozoan Pentapora fascialis. Marine Biology 126, 451-459.

Salas, C. \& Hergueta, E. 1986. Fauna de moluscos de las concreciones calcáreas de Mesophyllum lichenoides (Ellis) Lemoine. Estudio de la diversidad de un ciclo anual. Iberus 6, 57-65.

Santangelo, G. \& Abbiati, M. 2001. Red coral: conservation and management of an over-exploited Mediterranean species. Aquatic Conservation of Marine and Freshwater Ecosystems 11, 253-259.

Santangelo, G., Abbiati, M., Giannini, F. \& Cicogna, F. 1993. Red coral fishing trends in the western Mediterranean Sea during the period 1981-1991. Scientia Marina 57, 139-143.

Santangelo, G., Carletti, E., Maggi, E. \& Bramanti, L. 2003. Reproduction and population sexual structure of the overexploited Mediterranean red coral Corallium rubrum. Marine Ecology Progress Series 248, 99-108.

Sarà, M. 1968. Un coralligeno di piattaforma (coralligène de plateau) lungo il littorale pugliese. Archivi di Oceanografia e Limnologia 15 (Suppl.), 139-150.

Sarà, M. 1969. Research on coralligenous formation: problems and perspectives. Pubblicazioni della Stazione Zoologica di Napoli 37, 124-134.

Sartoretto, S. 1994. Structure et dynamique d'un nouveau type de bioconstruction à Mesophyllum lichenoides (Ellis) Lemoine (Corallinales, Rhodophyta). Comptes Rendus de l'Académie des Sciences Série III, Life Sciences 317, 156-160.

Sartoretto, S. 1996. Vitesse de croissance et bioérosion des concrétionnements "coralligènes" de Méditerranée nord-occidentale. Rapport avec les variations Holocènes du niveau marin. Thèse Doctorat d'Écologie, Université d'Aix-Marseille, II.

Sartoretto, S. 1998. Bioérosion des concrétions coralligènes de Méditerranée par les organismes perforants: essai de quantification des processus. Comptes Rendus de l'Académie des Sciences Séries IIA, Earth and Planetary Sciences 327, 839-844.

Sartoretto, S. \& Francour, P. 1997. Quantification of bioerosion by Sphaerechinus granularis on "coralligène" concretions of the western Mediterranean. Journal of the Marine Biological Association of the United Kingdom 77, 565-568.

Sartoretto, S., Francour, P., Harmelin, J.G. \& Charbonnel, E. 1997. Observations in situ de deux Labridae profonds, Lappanella fasciata et Acantholabrus palloni, en Méditerranée nord-occidentale. Cybium 21, 37-44.

Sartoretto, S., Verlaque, M. \& Laborel, J. 1996. Age of settlement and accumulation rate of submarine "coralligène" (-10 to $-60 \mathrm{~m})$ of the northwestern Mediterranean Sea; relation to Holocene rise in sea level. Marine Geology 130, 317-331.

Simkiss, K. 1964. Phosphates as crystalpoisons of calcification. Biological Reviews 39, 487-505.

Spanier, E. 1991. Artificial reefs to insure protection of the adult Mediterranean slipper lobster, Scyllarides latus. In Les Espèces Marines à Protéger en Méditérranée, C.F. Boudouresque et al. (eds), Marseille: GIS Posidonie, 179-185.

Templado, J. 1991. Las especies del género Charonia (Mollusca: Gastropoda) en el Mediterráneo. In Les Espèces Marines à Protéger en Méditérranée, C.F. Boudouresque et al. (eds), Marseille: GIS Posidonie, 133-140. 


\section{ENRIC BALLESTEROS}

Templado, J., García-Carrascosa, M., Baratech, L., Capaccioni, R., Juan, A., López-Ibor, A., Silvestre, R. \& Massó, C. 1986. Estudio preliminar de la fauna asociada a los fondos coralíferos del mar de Alborán (SE de España). Boletín Instituto Español de Oceanografía 3, 93-104.

Torrents, O., Garrabou, J., Marschal, C. \& Harmelin, J.G. 2005. Age and size at first reproduction in the commercially exploited red coral Corallium rubrum (L.) in the Marseilles area (France, NW Mediterranean). Biological Conservation 121, 391-397.

Tortonese, E. 1958. Bionomia marina della regione costiera fra punta della Chiappa e Portofino (Riviera Ligure di Levante). Archivi di Oceanografia e Limnologia 11, 167-210.

Tortonese, E. 1965. Fauna d'Italia. Echinodermata. Bologna: Calderini.

True, M.A. 1970. Étude quantitative de quatre peuplements sciaphiles sur substrat rocheux dans la région marsellaise. Bulletin de l'Institut Océanographique (Monaco) 69 (1401), 1-48.

Turon, X. 1990. Distribution and abundance of ascidians from a locality on the northeast coast of Spain. Pubblicazioni della Stazione Zoologoca di Napoli I: Marine Ecology 11, 291-308.

Turon, X. 1992. Periods of non-feeding in Polysyncraton lacazei (Ascidiacea: Didemnidae): a rejuvenative process? Marine Biology 112, 647-655.

Turon, X. 1993. Els ascidis: faunística i distribució. In Història Natural de l’Arxipèlag de Cabrera, J. A. Alcover et al. (eds), Monografies de la Societat d'Història Natural de Balears 2. Palma de Mallorca: CSIC-Ed. Moll, 607-621.

Turon, X. \& Becerro, M. 1992. Growth and survival of several ascidian species from the northwestern Mediterranean. Marine Ecology Progress Series 82, 235-247.

Turon, X., Galera, J. \& Uriz, M.J. 1997. Clearance rates and aquiferous systems in two sponges with contrasting life-history strategies. Journal of Experimental Zoology 278, 22-36.

Turon, X., Uriz, M.J. \& Willenz, P. 1999. Cuticular linings and remodelisation processes in Crambe crambe (Demospongiae: Poeciclosclerida). Memoirs of the Queensland Museum 44, 617-625.

Uriz, M.J., Martin, D., Turon, X., Ballesteros, E., Hughes, R. \& Acebal, C. 1991. An approach to the ecological significance of chemically mediated bioactivity in Mediterranean benthic communities. Marine Ecology Progress Series 70, 175-188.

Uriz, M.J., Rosell, D. \& Martin, D. 1992a. The sponge population of the Cabrera Archipelago (Balearic islands): characteristics, distribution, and abundance of the most representative species. Pubblicazioni della Stazione Zoologica di Napoli I: Marine Ecology 13, 101-117.

Uriz, M.J., Rosell, D. \& Maldonado, M. 1992b. Parasitism, commensalism or mutualism? The case of Scyphozoa (Coronatae) and horny sponges. Marine Ecology Progress Series 81, 247-255.

Uriz, M.J., Rosell, D. \& Martin, D. 1992c. Relationships of biological and taxonomic characteristics to chemically mediated bioactivity in Mediterranean littoral sponges. Marine Biology 113, 287-297.

Vadas, R.L. \& Steneck, R.S. 1988. Zonation of deep water benthic algae in the Gulf of Maine. Journal of Phycology 24, 338-346.

Vaissière, R. 1964. Contribution à l'étude bionomique de la Méditerranée Occidentale (côte du Var et des Alpes-Maritimes, côte occidentale de Corse). Fasc. 1: Generalités. Bulletin de l'Institut Océanographique (Monaco) 63 (1310), 1-12.

Vaissière, R. \& Fredj, G. 1963. Contribution à l'étude de la faune benthique du plateau continental de l'Algérie. Bulletin de l'Institut Océanographique (Monaco) 60 (1272), 1-83.

Velimirov, B. 1975. Wachstum und Altersbestimmung der Gorgonie Eunicella cavolinii. Oecologia 19, 259-272.

Vicente, N. \& Moreteau, J.C. 1991. Statut de Pinna nobilis L. en Méditerranée (Mollusque Eulamellibranche). In Les Espèces Marines à Protéger en Méditérranée, C.F. Boudouresque et al. (eds), Marseille: GIS Posidonie, 159-168.

Vighi, M. 1972. Étude sur la reproduction du Corallium rubrum (L.). Vie et Milieu Sèries A 23, 21-32.

Weinbauer, M.G. \& Velimirov, B. 1995a. Morphological variations in the Mediterranean sea fan Eunicella cavolini (Coelenterata: Gorgonacea) in relation to exposure, colony size and colony region. Bulletin of Marine Science 56, 283-295.

Weinbauer, M.G. \& Velimirov, B. 1995b. Biomass and secondary production of the temperate gorgonian coral Eunicella cavolini (Coelenterata, Gorgonacea). Marine Ecology Progress Series 121, 211-216. 


\section{MEDITERRANEAN CORALLIGENOUS ASSEMBLAGES}

Weinberg, S. 1979. The light-dependent behaviour of planulae larvae of Eunicella singularis and Corallium rubrum and its implication for octocorallian ecology. Bijdragen tot de Dierkunde 49, 16-30.

Weinberg, S. 1991. Faut-il protéger les gorgones de Méditerranée? In Les Espèces Marines à Protéger en Méditérranée, C.F. Boudouresque et al. (eds), Marseille: GIS Posidonie, 47-52.

Weinberg, S. \& Weinberg, F. 1979. The life cycle of a gorgonian: Eunicella singularis (Esper, 1794). Bijdragen tot de Dierkunde 48, 127-140.

Whitehead, P.J.P., Bauchot, M.L., Hureau, J.C., Nielsen, J. \& Tortonese, E. (eds). 1984-1986. Fishes of the North-Eastern Atlantic and the Mediterranean. Vols. I-III. Bungay: Chaucer.

Woelkerling, W.J. 1983. A taxonomic reassessment of Lithophyllum (Corallinaceae, Rhodophyta) based on studies of R.A. Philippi's original collections. British Phycological Journal 18, 299-328.

Woelkerling, W.J., Penrose, D. \& Chamberlain, Y.M. 1993. A reassessment of type collections of nongeniculate Corallinaceae (Corallinales, Rhodophyta) described by C. Montagne and L. Dufour, and of Melobesia brassica-florida Harvey. Phycologia 32, 323-331.

Wray, J.L. 1977. Calcareous Algae. Amsterdam: Elsevier.

Zabala, M. 1984. Briozous de les illes Medes. In Els Sistemes Naturals de les Illes Medes, J. Ros et al. (eds), Arxius Secció Ciències 73, 537-562.

Zabala, M. 1986. Fauna dels briozous dels Països Catalans. Arxius Secció Ciències 84, 1-833.

Zabala, M. \& Ballesteros, E. 1989. Surface-dependent strategies and energy flux in benthic marine communities or, why corals do not exist in the Mediterranean. Scientia Marina 53, 3-17.

Zabala, M., Garcia-Rubies, A., Louisy, P. \& Sala, E. 1997a. Spawning behaviour of the Mediterranean dusky grouper Epinephelus marginatus (Lowe, 1834) (Pisces, Serranidae) in the Medes islands Marine Reserve (NW Mediterranean, Spain). Scientia Marina 61, 65-77.

Zabala, M., Louisy, P., Garcia-Rubies, A. \& Gracia, V. 1997b. Socio-behavioural context of reproduction in the Mediterranean dusky grouper Epinephelus marginatus (Lowe, 1834) (Pisces, Serranidae) in the Medes islands Marine Reserve (NW Mediterranean, Spain). Scientia Marina 61, 79-89.

Zibrowius, H., Monteiro-Marques, V. \& Grashoff, M. 1984. La répartition du Corallium rubrum dans l'Atlantique (Cnidaria, Anthozoa: Gorgonaria). Téthys 11, 163-170. 
